\title{
MAGIA - RELIGIA - OSTENTACJA. KAPTORGI Z WCZESNOŚREDNIOWIECZNEGO CMENTARZYSKA W RADOMIU W UJĘCIU KOMPARATYSTYCZNYM
}

\author{
MAGIC - RELIGION - OSTENTATION. LOCKETS FROM \\ AN EARLY-MEDIEVAL GRAVE FIELD IN RADOM. \\ A COMPARATIVE APPROACH
}

\begin{abstract}
This article presents an analysis of two brass lockets, rectangular in shape, discovered in a richly equipped grave no. 62 in an early-medieval grave field in Radom (the $4^{\text {th }}$ quarter of the $11-12^{\text {th }}$ centuries). As a result of the analysis, their cognitive value can be estimated in a comprehensive way against the background of other finds of the type excavated in graves. On the other hand, it has allowed to enrich the knowledge of burying the dead with objects of magical and religious nature. The lockets discovered in Radom were made locally, most probably as imitations of more sophisticated pendants. Most probably, they were used as containers for magical or healing amulets, possibly contact relics (brandeum, eulogiae) or perfumes. They were probably buried after mid- $11^{\text {th }}$ century, during the religious transformation taking place in the early Piast state, bearing material testimony to the intertwining pagan rites and the ceremonies of the new faith.
\end{abstract}

Keywords: early Middle Ages, grave treasures, burial rites, Radom, locket, gold smithery.

\section{WSTĘP}

Nekropolię w Radomiu założono na wyniesieniu położonym niedaleko rzeki Mlecznej w pobliżu grodziska, tzw. Piotrówki, pomiędzy dzisiejszymi ulicami Limanowskiego i Przechodnią. Badania wykopaliskowe na tym stanowisku (nr 4) zostały zapoczątkowane w 1923 roku, wraz z przypadkowym odkryciem pierwszych pochówków, a ich kontynuacja nastąpiła po blisko dwudziestoletniej przerwie (w 1942 roku). Pozyskane wówczas znaleziska opublikował J. Gąssowski (1950-1951). Antropologicznej analizy doczekały się także szczątki kostne (Rosiński 1950-1951).

* ORCID 0000-0002-8158-1104, Ośrodek Badań nad Dawnymi Technologiami, Instytut Archeologii i Etnologii Polskiej Akademii Nauk, ul. Tylna 1, 90-364 Łódź, e-mail: tomasz.kurasinski@wp.pl. 
Kolejny etap badawczy wyznaczają szeroko zakrojone prace o charakterze ratowniczym podjęte w 1966 roku przez Wojciecha Twardowskiego, które przyczyniły się do odkrycia kolejnych pochówków. Łączna liczba grobów zarejestrowanych na cmentarzysku wyniosła 125. Poddano je wieloaspektowej analizie, której wyniki zostały przedstawione w monograficznym opracowaniu stanowiska. Ustalono, że zmarłych chowano między ostatnią ćwiercią XI wieku do końca następnego stulecia (Kurasiński i Skóra 2016).

Nie ulega wątpliwości, iż wiele poruszonych zagadnień związanych z nekropolią radomską wymaga dalszych pogłębionych studiów, zwłaszcza wobec stale poszerzającej się bazy źródłowej, pochodzącej z wczesnośredniowiecznych stanowisk. Dotyczy to także niektórych zabytków pozyskanych w Radomiu, a wśród nich dwóch dość rzadko notowanych przedmiotów - kaptorg. Ponowna ocena pozwoli z jednej strony wszechstronniej oszacować ich wartość poznawczą na tle innych tego rodzaju znalezisk, odnotowanych dotychczas na cmentarzyskach doby wczesnopiastowskiej, z drugiej zaś wzbogacić wiedzę na temat zjawiska wyposażania grobów w przedmioty o charakterze magiczno-religijnym.

\section{KONTEKST ODKRYCIA}

Kaptorgi okryto w grobie nr 62, zlokalizowanym w centralnej części przebadanej przestrzeni grzebalnej (ryc. 1) (Kurasiński i Skóra 2016, s. 145-146, tabl. XXII). Jama grobowa o zarysie prostokąta miała wymiary $260 \times 125 \mathrm{~cm}$ (na poziomie dna). Niezbyt dobrze zachowane szczątki ludzkie należały do kobiety zmarłej w wieku około 20-25 lat (Kurasiński i Skóra 2016, s. 145; Borowska-Strugińska i Kapla 2020, s. 87). Szkielet znajdował się na głębokości około $60 \mathrm{~cm}$ od powierzchni gruntu. Zmarłą pochowano głową skierowaną ku zachodowi, w układzie na wznak. Kończyny górne wyciągnięte były wzdłuż tułowia, przy czym pierwotny układ kości lewej kończyny górnej uległ zakłóceniu, być może w następstwie procesów podepozycyjnych. Kończyny dolne ułożono w pozycji wyprostowanej (ryc. 2).

W jamie grobowej natrafiono na liczne ozdoby. Z lewej strony czaszki znaleziono dwa esowate kabłączki skroniowe ze stopu miedzi (ryc. 2:5-6). Są to niewielkie egzemplarze (średnica wewnętrzna nie przekracza $13 \mathrm{~mm}$ ) należące do typu III odmiany A według klasyfikacji K. Musianowicz (1948-1949) i H. Kóčki-Krenz (1993, s. 47-48). Na paliczkach obydwu dłoni znajdowały się po dwa pierścionki, które wykonane zostały z mosiądzu i ze srebra (ryc. 2:14-17). Wszystkie reprezentują typ otwartej obrączki o zwężających się zakończeniach. Wykonano je z drutu, przy czym jeden $\mathrm{z}$ okazów upleciony został $\mathrm{z}$ trzech srebrnych drucików. W okolicy szyi zalegały pozostałości kolii, złożonej z kilku paciorków szklanych, pomiędzy którymi zalegały omawiane kaptorgi (ryc. 2:7-8, 3). Powyżej kości lewej ręki, na wysokości biodra odkryto żelazne przedmioty o starszej niż wczesnośredniowieczna 


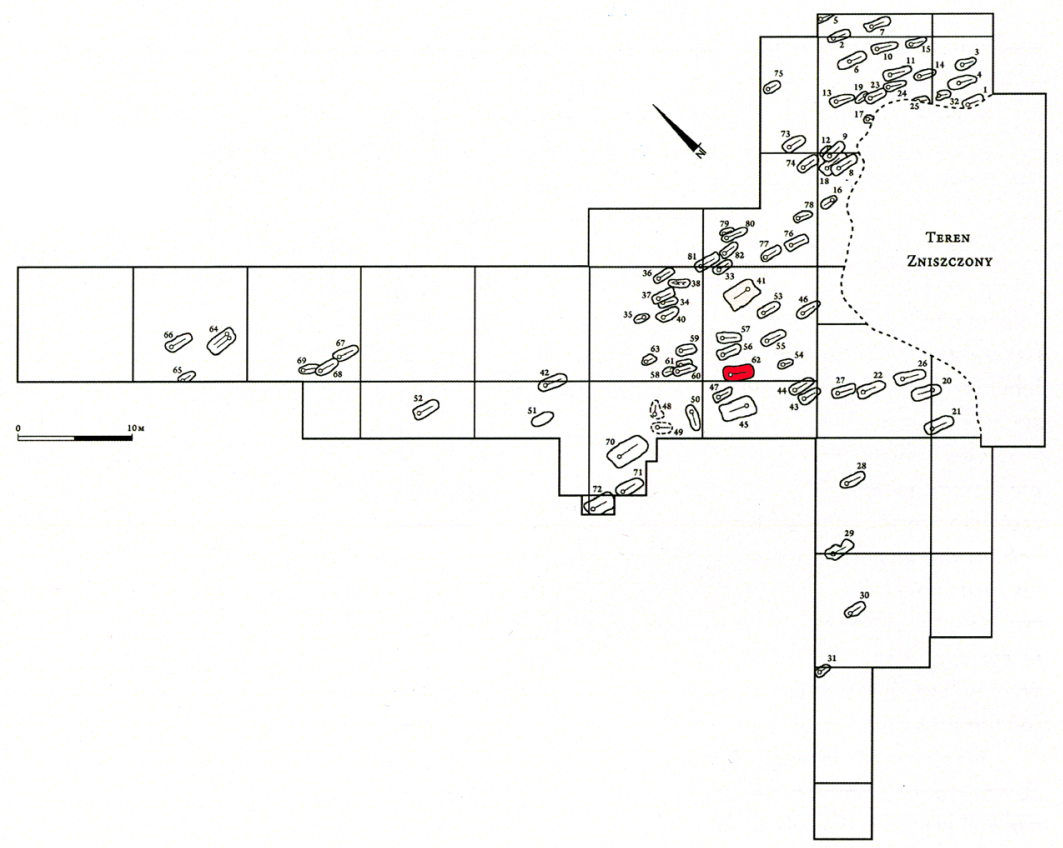

Ryc. 1. Plan cmentarzyska w Radomiu z zaznaczoną lokalizacją grobu nr 62 zawierającego kaptorgi (wg Kurasiński i Skóra 2016, ryc. 24). Oprac. T. Kurasiński

metryce. Były to sprzączka od pasa o pogrubionej ramie, z półelipsoidalną skuwką i ruchomym kolcem (ryc. 2:10) oraz nit o szerokiej główce i zgiętym w połowie długości trzpieniu, pochodzący przypuszczalnie z drewnianej skrzyneczki (ryc. 2:11). Przedmioty te pierwotnie poddane zostały działaniu ognia. Sprzączka pochodzi z wczesnej fazy okresu wędrówek ludów, podobną lub wcześniejszą metrykę miał zapewne także nit (szerzej na temat tych zabytków zob. Skóra i Kurasiński 2012). Skład grobowego wyposażenia uzupełniało zniszczone naczynie gliniane, pierwotnie ustawione przy lewym łokciu zmarłej kobiety (ryc. 2:1). Charakteryzuje się ono esowatym profilem, wyodrębnioną szyjką i wrębem na pokrywę. Zdobiony jest dookolnymi żłobkami, obejmującymi większą część powierzchni naczynia, a na listwie w dolnej partii szyjki widoczne są plastyczne zagniecenia.

Z grobu wydobyto ponadto przedmioty, których miejsce zalegania w jamie grobowej jest nieznane, tak przynajmniej wynika z dokumentacji. Są to dwa niewielkie okucia mosiężne, stanowiące najprawdopodobniej część rzemienia lub pasa (ryc. 2:12-13), fragmenty czterozwojowego drucika ze stopu miedzi oraz zachowany w dwóch częściach przedmiot żelazny, być może pozostałość noża lub sprzączki (ryc. 2:9). Podczas przesiewania ziemi pochodzącej z wnętrza jamy grobowej odkryto także gwóźdź żelazny oraz nasiona winorośli, będące tematem odrębnego omówienia (Kurasiński i Skóra 2013). 

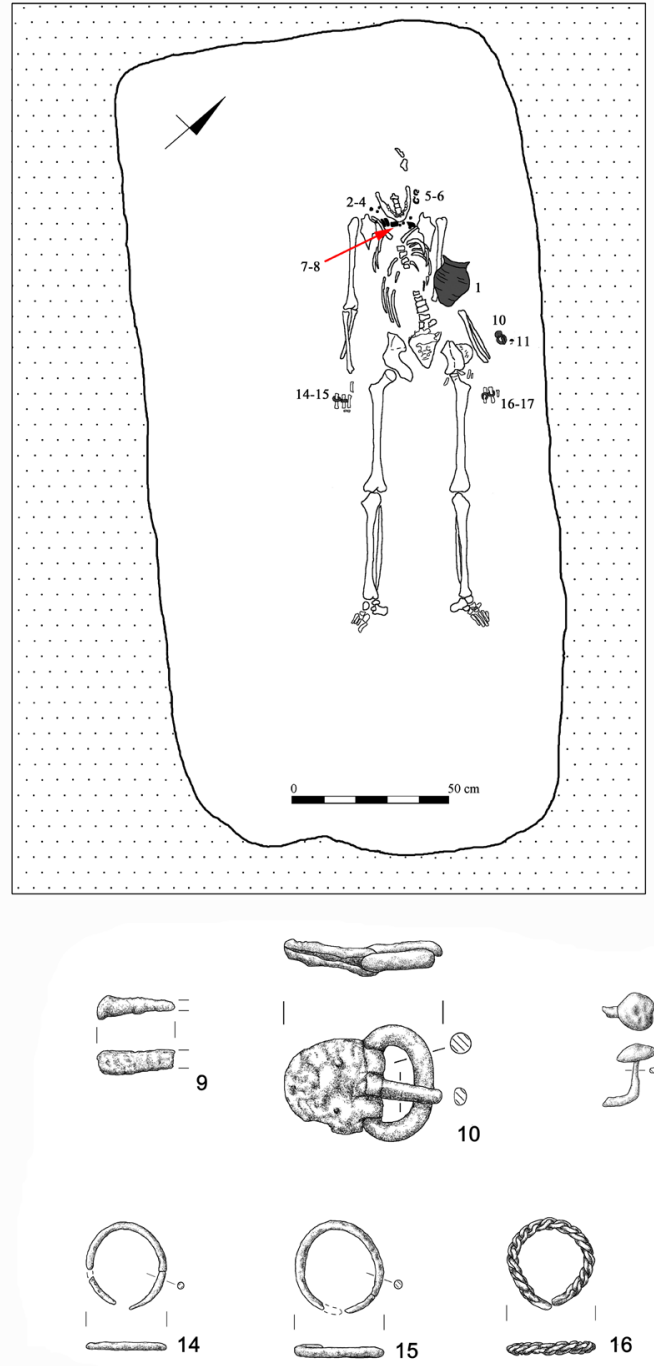
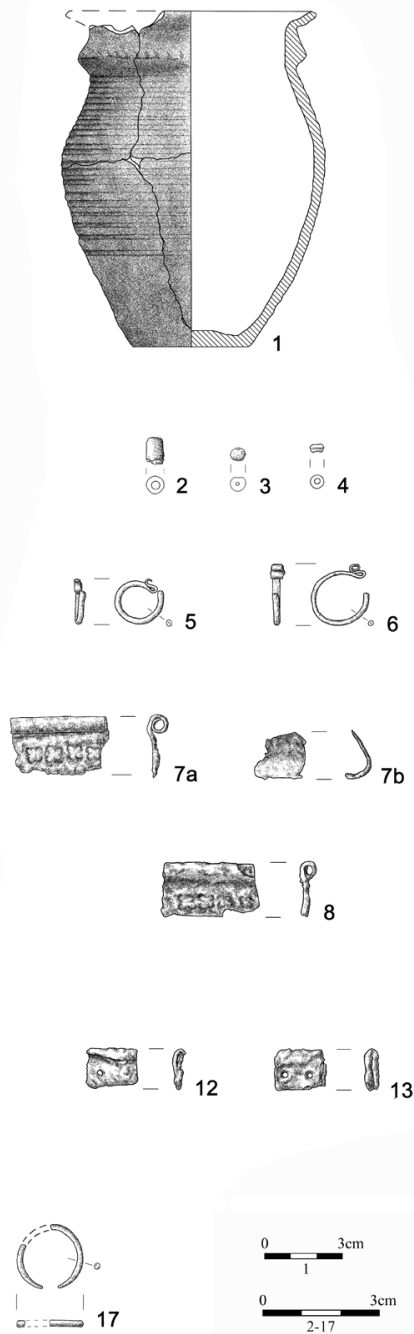

Ryc. 2. Grób nr 62 z Radomia

1 - naczynie gliniane; 2-4 - paciorki szklane; 5-6 - kabłączki skroniowe z brązu; 7-8 - kaptorgi z mosiądzu; 9 - fragment przedmiotu żelaznego; 10 - sprzączka żelazna; 11 - nit żelazny; 12-13 - okucia z mosiądzu; 14-17 - pierścionki ze srebra i mosiądzu (wg Skóra i Kurasiński 2011, ryc. 2). Rys. J. Słomska, oprac. T. Kurasiński 


\section{CHARAKTERYSTYKA ZABYTKÓW}

Na podstawie zachowanych pozostałości należy sądzić, że do grobu trafiły dwie kaptorgi. W najlepszym stanie znajdują się dwie czworokątne blaszki z rurkowatymi uszkami, stanowiące lica omawianych przedmiotów (ryc. 2:7-8, 3) ${ }^{1}$. Na obu widoczne są zdobienia w postaci wytłoczonego prostokąta, w który wpasowane zostały cztery ułożone horyzontalnie i wyciskane od wewnątrz guzki, najbardziej przypominające rozetki. Znajdują się one bezpośrednio pod rurkowatym uchwytem. Obydwa fragmenty zawieszek mają bardzo zbliżone wymiary (około $25 \times 15 \mathrm{~mm}$ ).

W archeologicznej terminologii kaptorga najogólniej definiowana jest jako rodzaj niewielkiej zawieszki w postaci zamkniętej, zazwyczaj metalowej kapsułki. Na podstawie kształtu w polskiej literaturze przedmiotu wyodrębnia się dwa typy takich przedmiotów, różniące się ponadto techniką wykonania, konstrukcją i sposobem zdobienia - prostokątny i trapezowaty (Kostrzewski 1965, s. 371; Sztyber 2008, s. 283; 2010, s. 43). Te pierwsze mają formę schowków o przekroju migdałowatym, uzyskanym poprzez odpowiednie zwinięcie pasma blachy, najczęściej srebrnej, rzadziej ze stopów miedzi. Boki zamknięte były łezkowatymi w kształcie ściankami. Z górnej krawędzi formowano rurkowaty uchwyt, służący do przewleczenia sznurka, tasiemki lub rzemyka i zawieszeniu przedmiotu na szyi. Okazy należące do tej grupy z reguły są zdobione filigranem, granulacją, puncowaniem i różnego rodzaju motywami plastycznymi (Stattler 1966, s. 234; Kóčka-Krenz 1993, s. 84; 2014, s. 34; Grzegorczyk 2009, s. 3; Sztyber 2010, s. 45). Z kolei kaptorgi trapezowate posiadają oddzielne ruchome wieczko z otworami do zawieszania. Podobnie jak w poprzednio opisanym typie, są to przede wszystkim okazy srebrne, przy czym przy ich wytwarzaniu stosowana była inna technika zdobnicza - przede wszystkim wytłaczanie w odpowiednich formach, a jako element uzupełniający pojawia się niekiedy ornamentyka ryta i punktowa oraz wykorzystująca filigran. W ich zdobnictwie najczęściej sięgano po motywy zoomorficzne i roślinne, które otaczała szeroka bordiura (Stattler 1966, s. 235-236; Kóčka-Krenz 1993, s. 86-87; 2014, s. 34; Grzegorczyk 2009, s. 4; Sztyber 2008, s. 283; 2010, s. 45$)^{2}$.

W świetle powyższego podziału odkryte w Radomiu kaptorgi spełniają kryteria przyjęte dla typu grupującego okazy prostokątne.

$\mathrm{Na}$ podstawie analizy spektralnej można stwierdzić, iż egzemplarze z Radomia wykonane zostały z mosiądzu o dość wysokiej zawartości cynku (zob. tab. 1; Gan

${ }^{1}$ Zainwentaryzowane pod osobnymi numerami katalogowymi ułamki blaszek w większości stanowią tylną część opisywanych kaptorg.

${ }^{2}$ Inne kryterium klasyfikacyjne zaproponował I. Štefan (2004, s. 24-28), dzieląc okazy zebrane z Moraw i Czech na podstawie techniki ich wykonania. Wyróżnione zostały przez niego dwie zasadnicze grupy: okazy z aplikowanymi motywami zdobniczymi (s aplikovanou výzdobou) oraz okazy z motywami wyciskanym i wybijanymi (s vytepávanou výzdobou). Ponadto wydzielono pojedyncze egzemplarze niezdobione. Z kolei w pracy N. Profantovej i A. Šilhovej (2010, s. 298-302, ryc. 13) materiał czeski podzielono na sześć typów, o czym zdecydowały detale konstrukcyjne i technologiczne. 


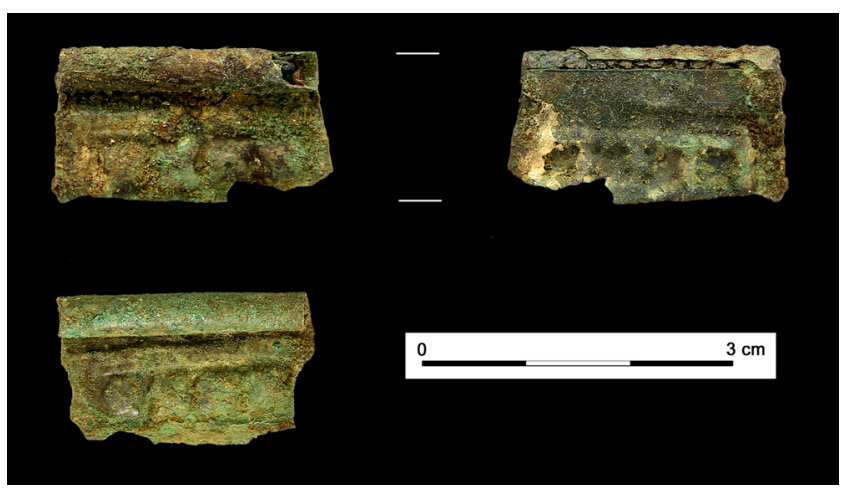

Ryc. 3. Kaptorgi z Radomia. 1 - nr inw. MR.A.819c/191/66; 2 - nr inw. MR.A.819c/181/66. Fot. J. Słomska, oprac. T. Kurasiński

i Pawlicka 2020, s. 204) $)^{3}$. Do ich wyrobu użyto prawdopodobnie surowca o różnym pochodzeniu, co sugerują różnice w procentowym składzie pierwiastkowym.

W rurkowatych uchwytach stwierdzono pozostałości włókien roślinnych, najprawdopodobniej lnianych ${ }^{4}$.

\section{KAPTORGI RADOMSKIE NA TLE INNYCH ZNALEZISK}

Kaptorgi pochodzą przede wszystkim z terenów słowiańskich. Oprócz dzisiejszej Polski, skąd bierze swój początek ponad 100 egzemplarzy (nie licząc złomu kruszcowego), duży zbiór tego rodzaju zawieszek uzyskany został na terenie Czech i Moraw, głównie z cmentarzysk (Štefan 2004; Profantová i Šilhová 2010; Profantová, Špaček i Novotná 2011; Profantová i Daněček 2017; Frolíková, Ottenwelter i Barčáková 2020). Omawiane ozdoby używane były także na Rusi (Korzukhina 1954, s. 99, tabl. XXIII:19; Eniosova i Pushkina 1997, s. 67, ryc. 9; Zhilina 2008), w Bułgarii Nadwołżańskiej (Rudenko 2011, s. 151, 154, 155, 157, ryc. 2, 13:2, 10) i na terytorium połabskim (Kóčka-Krenz 1993, s. 235); Anders 2013, s. 34-35). Sporadycznie spotyka się je również w Skandynawii (Birka - Arbman 1940, tabl. 92:16a-b; 1943, s. 199; Haithabu - Arents i Eisenschmidt 2010a, s. 125-127; 2010b, s. 194-195, tabl. 91), gdzie najczęściej reprezentowane są w skarbach gotlandzkich z końca X - 1. połowy XI wieku i bornholmskich z 2. połowy X - początku XII wieku (Stenberger 1958, s. 181-185; Czonstke 2009-2010, s. 173,

${ }^{3}$ Badania przeprowadzone zostały w Laboratorium Bio- i Archeometrii Instytutu Archeologii i Etnologii PAN w Warszawie. Analizy wykonano za pomocą mikroskopu skaningowego TESCAN Vega $5135 \mathrm{MM} \mathrm{z}$ analizatorem AVALON PGT - Princeton Gamma Tech (SEM-EDS), wykorzystując metody fluorescencji rentgenowskiej.

${ }^{4}$ Informację tę zawdzięczam mgr. Łukaszowi Antosikowi z Ośrodka Badań nad Dawnymi Technologiami PAN w Łodzi, któremu składam podziękowania. 
183-184, ryc. 5; 2018, s. 98, 99, 103). Sporadycznie notuje się je także w grobach południowo-wschodniego Bornholmu (Naum 2005-2006, s. 24, 33; 2008, s. 213). W środowisku skandynawskim kaptorgi postrzega się jako efekt oddziaływania świata słowiańskiego.

Na terenie Polski kaptorgi także pojawiają się głównie w skarbach, do których trafiały niemal zawsze w postaci pofragmentowanej (Kóčka-Krenz 1993, s. 86-87, 232-236; z nowszych opracowań zob. np. Kóčka-Krenz 2000, s. 99, 102, ryc. 1:9; Andrałojć, Andrałojć i Tuszyński 2005, s. 113-114, 152, tabl. II/IV; Gągorowska-Chudobska 2013, s. 309-310, ryc. 19; Nowakiewicz 2013, s. 150, 158), choć zdarzały się też całe, dobrze zachowane egzemplarze odmiany trapezowatej (z ostatnich znalezisk zob. Czonstke i Koperkiewicz 2013, s. 225-227, 242, tabl. I:6). Rzadziej notuje się je na grodziskach (np. Biskupin - Zawol 2015; Lubin - Janowski 2011, s. 475, ryc. 8; Ostrów Lednicki - Banaszak i Tabaka 2017; Wrocław-Ostrów Tumski - Rodak 2017, s. 115-116, ryc. 14) i na osadach (np. Bodzia - Wiśniewski i Kotlewski [red.] 2013, ryc. na s. 116; Wszemirów - Paternoga 2003, 164-165, ryc. 15; Dąbrowa Górnicza-Łosień - Rozmus i Szmoniewski 2010, s. 135, 136, ryc. $5:$ h) oraz cmentarzyskach. Z uwagi na kontekst omawianego znaleziska szczególnie interesować nas będzie ten ostatni rodzaj stanowisk.

Wraz z okazami radomskimi omawiane zawieszki weszły w skład wyposażenia pośmiertnego 29 udokumentowanych grobów, odkrytych na 22 nekropoliach (ryc. 4). Jest to zbiór mocno zróżnicowany pod względem formy, zdobnictwa i techniki wykonania (zob. ryc. 5-11).

Pomijając cmentarzysko w Radomiu, kaptorgi zostały znalezione w Bodzi, stan. 1, groby nr D1486, E72 i E864/II - 3 egz. (ryc. 8:1-2) (Duczko 2016, s. 139-143, ryc. 3.4.7-8; Sobkowiak-Tabaka 2016, s. 67, 75, 79), Cedyni, stan. 2, grób nr $30-1$ egz. (ryc. 11:1) (Porzeziński 2006, s. 35-36, 194, tabl. XXXVII:i), Ciepłem, stan. 6, grób nr 6 - 2 egz. (ryc. 5:1) (Łęga 1930, s. 168, 612, tabl. XL:214; Ratajczyk i Wadyl 2019, s. 17), Dąbrowie Górniczej-Strzemieszycach Wielkich, stan. ?, grób nr 58 - 1 egz. (ryc. 8:3) (Marciniak 1960, s. 157, 170-171, tabl. V:13); Dziekanowicach, stan. 22, groby $\mathrm{nr} 7 / 96,28 / 01,106 / 05^{7}$ i 62/08 - 19 egz. (ryc. 5:2-18; 8:4, 9) (Wrzesiński 2015, s. 28-30, 33-42, ryc. 15-28; 2019, s. 70-75, tabl. 21:2-3. 73:12, 134:4-5, 167:2, 168:51-52, 196, 170:56, 171-172, 173:63-64), Gieczu, stan. 4, grób nr 3/05 - 1 egz. (ryc. 6:1-14) (Indycka 2016, s. 229, ryc. 10) ${ }^{8}$;

5 W starszej literaturze znalezione we Wszemirowie dwie kaptorgi opisywane były jako pochodzące z grobu ciałopalnego (Kaźmierczyk 1966, s. 37), wchodzącego w skład większego cmentarzyska. W świetle późniejszych ustaleń przekonanie to nie znalazło żadnego uzasadnienia. Stanowisko okazało się kilkufazową osadą z wczesnego średniowiecza (Paternoga 2003).

${ }^{6}$ Według W. Duczko znalezione w tym grobie metalowe ułamki należy interpretować nie jako kaptorgę, a pozostałości srebrnego paciorka (Duczko 2016, s. 141).

7 Należałoby zastanowić się, czy znalezione fragmenty wieczka i niezdobionej ścianki tylnej, uznane jako pozostałości dwóch kaptorg (Wrzesiński 2019, s. 70) nie należały - tak jak podawano wcześniej (Wrzesiński 2015, s. 33) - do jednego egzemplarza.

${ }^{8}$ Wcześniejsze doniesienia informują o większej liczbie okazów (Krzyszowski i Silska 2006, s. 5). 


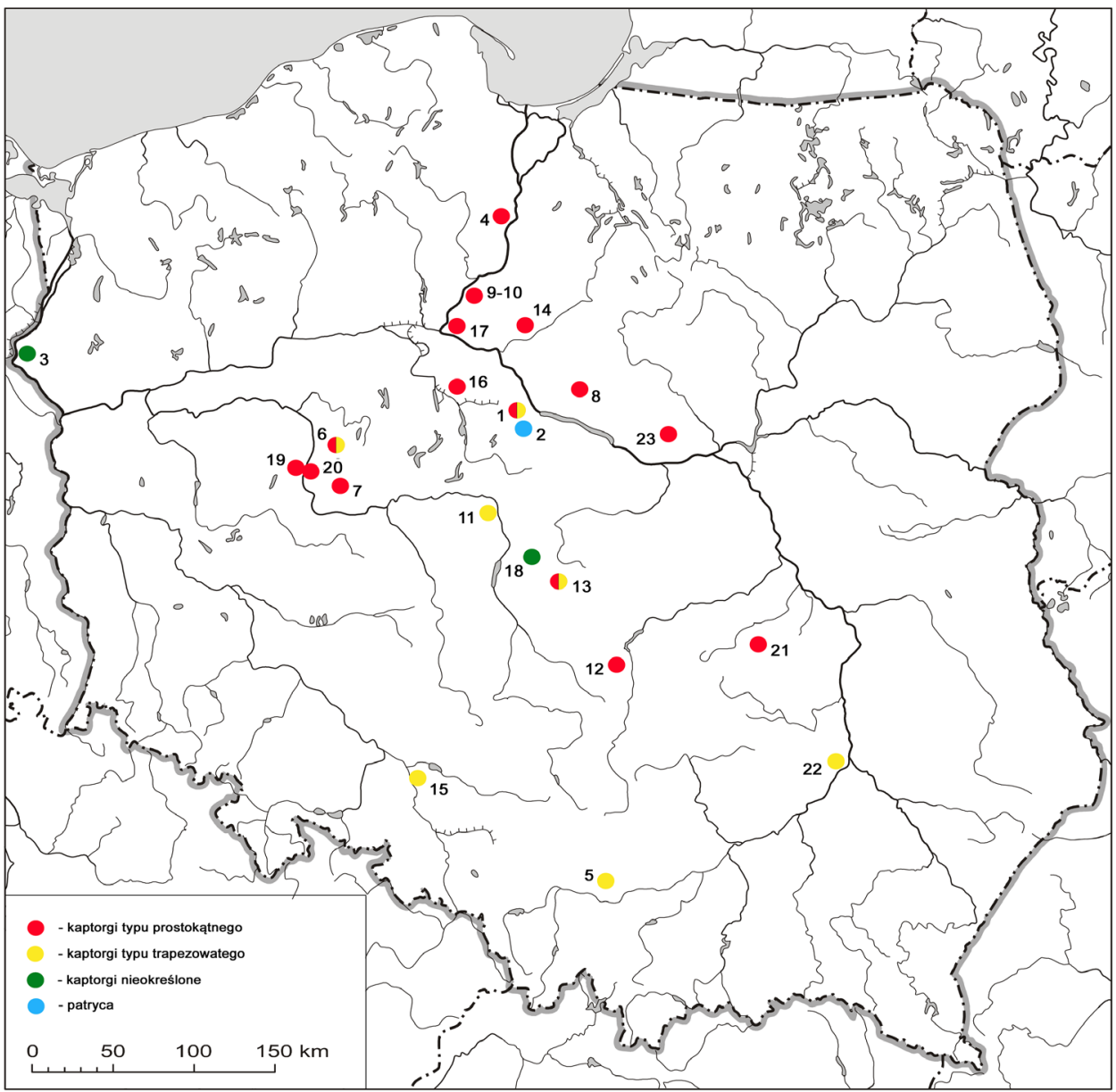

Ryc. 4. Mapa rozprzestrzenia kaptorg z wczesnośredniowiecznych cmentarzysk na terenie ziem polskich

1 - Bodzia, pow. włocławski; 2 - Brześć Kujawski, pow. włocławski; 3 - Cedynia, pow. gryfiński; 4 - Ciepłe, pow. tczewski; 5 - Dąbrowa Górnicza-Strzemieszyce Wielkie, pow. loco; 6 - Dziekanowice, pow. gnieźnieński; 7 - Giecz, pow. średzki; 8 - Gozdowo, pow. sierpecki; 9 - Kałdus, stan. 1, pow. chełmiński; 10 - Kałdus, stan. 4, pow. chełmiński; 11 - Kwiatków, pow. turecki; 12 - Lubień, pow. piotrkowski; 13 - Lutomiersk, pow. pabianicki; 14 - Napole, pow. golubsko-dobrzyński; 15 - Opole-Groszowice, pow. loco; 16 - Parchanki, pow. inowrocławski; 17 - Pień, pow. bydgoski; 18 - Poddębice, pow. loco; 19 - Poznań-Sołacz, pow. loco; 20 - Poznań-Śródka, pow. loco; 21 - Radom, pow. loco; 22 - Sandomierz, pow. loco; 23 - Żukowo, pow. płoński. Oprac. T. Kurasiński 
Gozdowie, stan. 1A, grób nr 8 - 2 egz. (ryc. 6:15-16) (Musianowicz 1950-1951, s. 258, 294, tabl. LXIV:3b) ${ }^{9}$, Kałdusie, stan. 1, grób nr 27/57 - 1 egz. (ryc. 6:17) (Kaszewska 1960, s. 150, 160, 173, tabl. XXVI:19; Drozd 2006, s. 81; Stawska, Weinkauf i Kozłowski 2006, s. 330, tabl. 8:1a) i stan. 4, grób nr 13B/00 - 8 egz. (ryc. 6:18-25) (Chudziak 2001, s. 74, ryc. 7:b; Chudziak, Bojarski i Stawska 2010a, s. 87; Bojarski, Chudziak, Drozd, Koperkiewicz, Kozłowski i Stawska 2010, s. 441, tabl. 2:a), Kwiatkowie, stan. 11, grób nr 282 - 1 egz. (ryc. 10:1) (Rzepecki, Kot i Piotrowska 2016, s. 127, ryc. 79) ${ }^{10}$, Lubieniu, stan. 1, grób nr 36 - 1 egz. (ryc. 6:26) (Kurasiński i Skóra 2012, s. 96-98, 174, tabl. XXVII:2), Lutomiersku, stan. 1, groby nr 10/41 i 22/49 - 2 egz. (ryc. 6:27, 10:2) (Nadolski, Abramowicz i Poklewski 1959, s. 81-82, tabl. LXIV:1-2), Napolu, stan. 16, grób nr $14-7$ egz. (ryc. 7:1-11) (Stawska 2003, s. 99; Bojarski 2014, s. 177, ryc. 3:h), Opolu-Groszowicach, stan. ?, grób nr 38 - 1 egz. (ryc. 10:3) (Urbańska 1959, s. 177, 183, tabl. V:8-9; Wachowski 1975, s. 60, 111, ryc. 18:48; Holc 2005), Parchankach, stan. 25, grób nr 6 - 3 egz. (ryc. 7:12-14) (Kóčka-Krenz 1995), Pniu, stan. 9, groby nr 32/06, 57/07 i 69/09 - 6 egz. (ryc. 7:15-19) (Drozd, Janowski i Poliński 2009, s. 354, 359; 2011, s. 515, ryc. 5:b; Błaszczyk 2020a, s. 105-109, ryc. 26-28; Błaszczyk, Drozd-Lipińska i Poliński 2020, s. 323, 343, 351, tabl. 12:c1, 25:f, 27:b), Poddębicach, stan. 2, grób nr 9 - 1 egz. (ryc. 11:2) (Wiklak 1960, s. 193, tabl. XLVI:2), Poznaniu-Solaczu, stan. 14, grób nr 9 - 1 egz. (ryc. 7:20) (Kurnatowska i Kara 2005, s. 11, ryc. 3:6; Kara 2017, s. 143, 145, ryc. 4:6) $)^{11}$; Poznaniu-Śródce, stan. Rynek Śródecki 7, grób nr 7 - 2 egz. (ryc. 7:21-22) (Kóčka-Krenz, Pawlak i Sikorski 1995; Pawlak 1997, s. 19-20, ryc. 10:m-o; 1998, s. 231, 258-260, ryc. 12:m-o; Pawlak i Pawlak 2015, s. 71-72, ryc. 59:4-6, 72)12, Sandomierzu,

9 W opracowaniu materiałowym cmentarzyska nie mówi się wprost o kaptordze. Znalezisko określone zostało jako „dwa kawałki blaszki brązowej, zgiętej podwójnie z jakiegoś bliżej nieokreślonego przedmiotu”, przypuszczalnie ,ze zniszczonej ozdoby lub naszycia na odzieży” (Musianowicz 1950-1951, s. 258, 294). Według T. Kordali, z uwagi na fakt, że przedmioty te w grobie znajdowały się w okolicy szyi, wśród paciorków „nie można wykluczyć, iż stanowiły one składnik kolii” (Kordala 2006, s. 173). Jakkolwiek w opinii J. Cichońskiej ,zabytek swym wyglądem przypomina fragment okucia”, autorka nie wyklucza, że mogła to być kaptorga (Cichońska 2017, s. 328, przyp. 23). Uwzględniając kształt przedmiotu oraz jego lokalizację, interpretacja taka wydaje się odpowiadać rzeczywistości.

${ }_{10}$ Pochówek znany jedynie $\mathrm{z}$ doniesień internetowych i wymienionej publikacji popularnonaukowej. Bliższych informacji na jego temat udzielił mgr Eryk Schellner, za co składam podziękowania. W grobie znaleziono liczne ozdoby, w tym elementy kolii (m.in. paciorki ze stopu miedzi, srebra i kamieni półszlachetnych), do której należała najpewniej kaptorga. Ponadto natrafiono na pierścionek, monetę, nóż i pozostałości wiadra klepkowego. Płci i wieku zmarłego nie można określić, gdyż zachował się jedynie nikły zarys szkieletu.

${ }^{11} \mathrm{~W}$ wymienionych publikacjach mowa jest o zawieszce nawiązującej do kaptorg prostokątnych. Na podstawie opisu (,rurkowata” forma) i zamieszczonej ryciny można jednak z dużym prawdopodobieństwem włączyć ją do omawianej kategorii przedmiotów.

${ }^{12} \mathrm{Na}$ tym stanowisku w 2017 roku być może odkryto jeszcze jedną kaptorgę, choć nie zostało to definitywnie potwierdzone (Pawlak i Pawlak 2018, s. 185). 

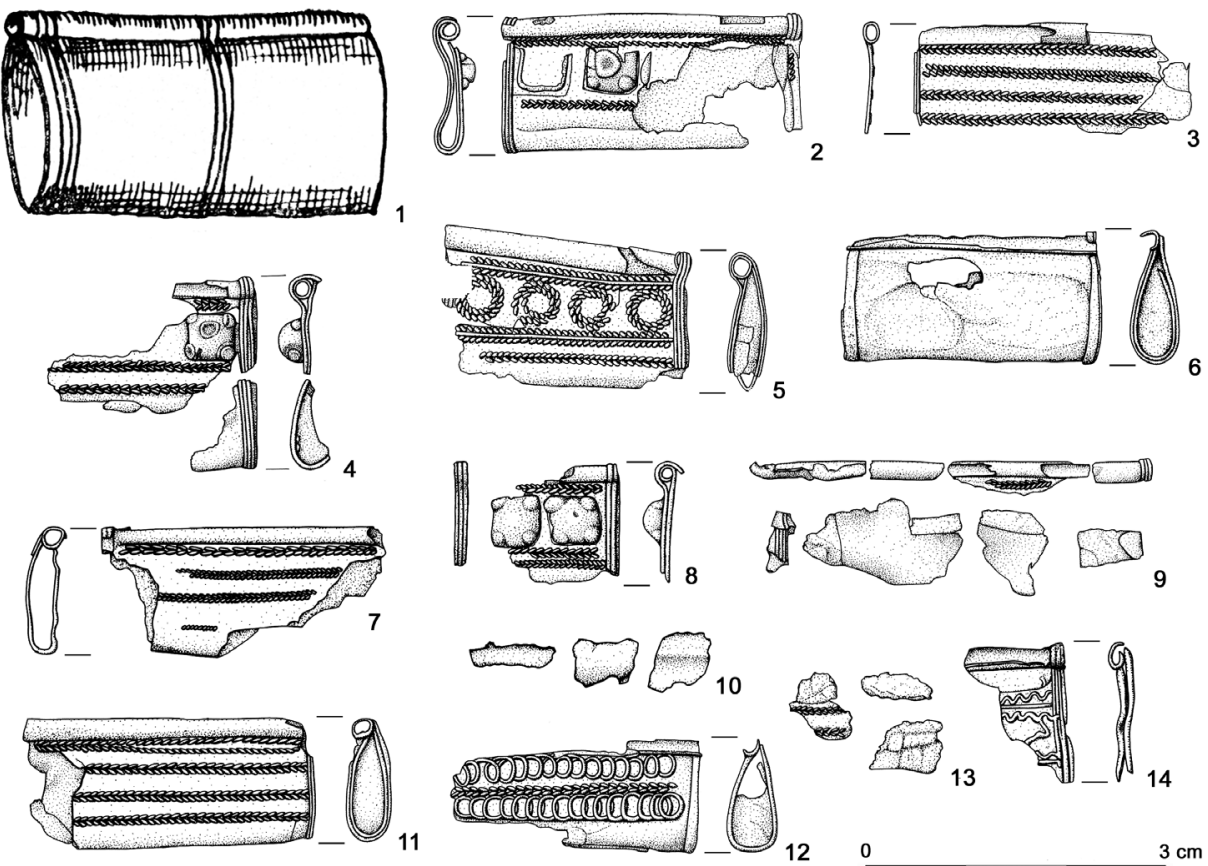

12 $3 \mathrm{~cm}$
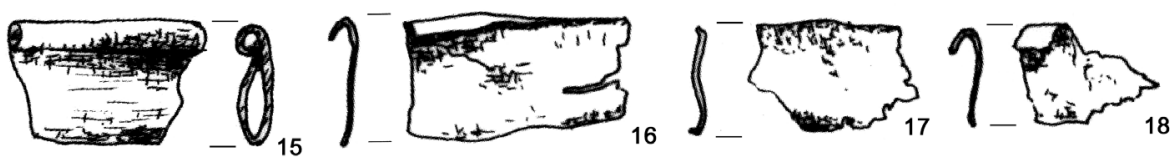

Ryc. 5. Kaptorgi typu prostokątnego z cmentarzysk. 1 - Ciepłe, grób nr 6 (wg Łęga 1930, tabl. XL:214); 2-14 - Dziekanowice, grób nr 62/08 (wg Wrzesiński [red.] 2019, tabl. 168:51-52, 169:54, 170:56, 171-172, 173:63-64); 15-18 - Dziekanowice, grób nr 7/96 (wg Wrzesiński [red.] 2019, tabl. 21:2-3). Oprac. T. Kurasiński

stan. przy kościele św. Jakuba, grób nr 7 - 1 egz. (ryc. 10:4) (Gąssowski 1969, s. 403-404, ryc. 69:a-b).

Listę tę należałoby uzupełnić o „luźno” znaleziony okaz z Żukowa, stan. 1 (ryc. 7:23), który pierwotnie zapewne znajdował się w jednym ze zniszczonych pochówków (Cichońska 2017, s. 326, ryc. 2:2-3). Dla pełnego obrazu należy wspomnieć o patrycy do wytłaczania kapsułek z Brześcia Kujawskiego, stan. 5, znalezionej w grobie nr 160 (ryc. 12) (Jażdżewski 1937, s. 104-105, ryc. 6; Jakimowicz 1939, s. 379-381; Kaszewscy 1971, s. 379, 382, tabl. VIII:12).

Najczęściej obserwowana jest sytuacja, gdy na cmentarzysku znajdował się jeden grób wyposażony w rozpatrywane przedmioty. Niekiedy jednak takich obiektów było więcej. I tak, w Dziekanowicach pochówki z kaptorgami były cztery, 


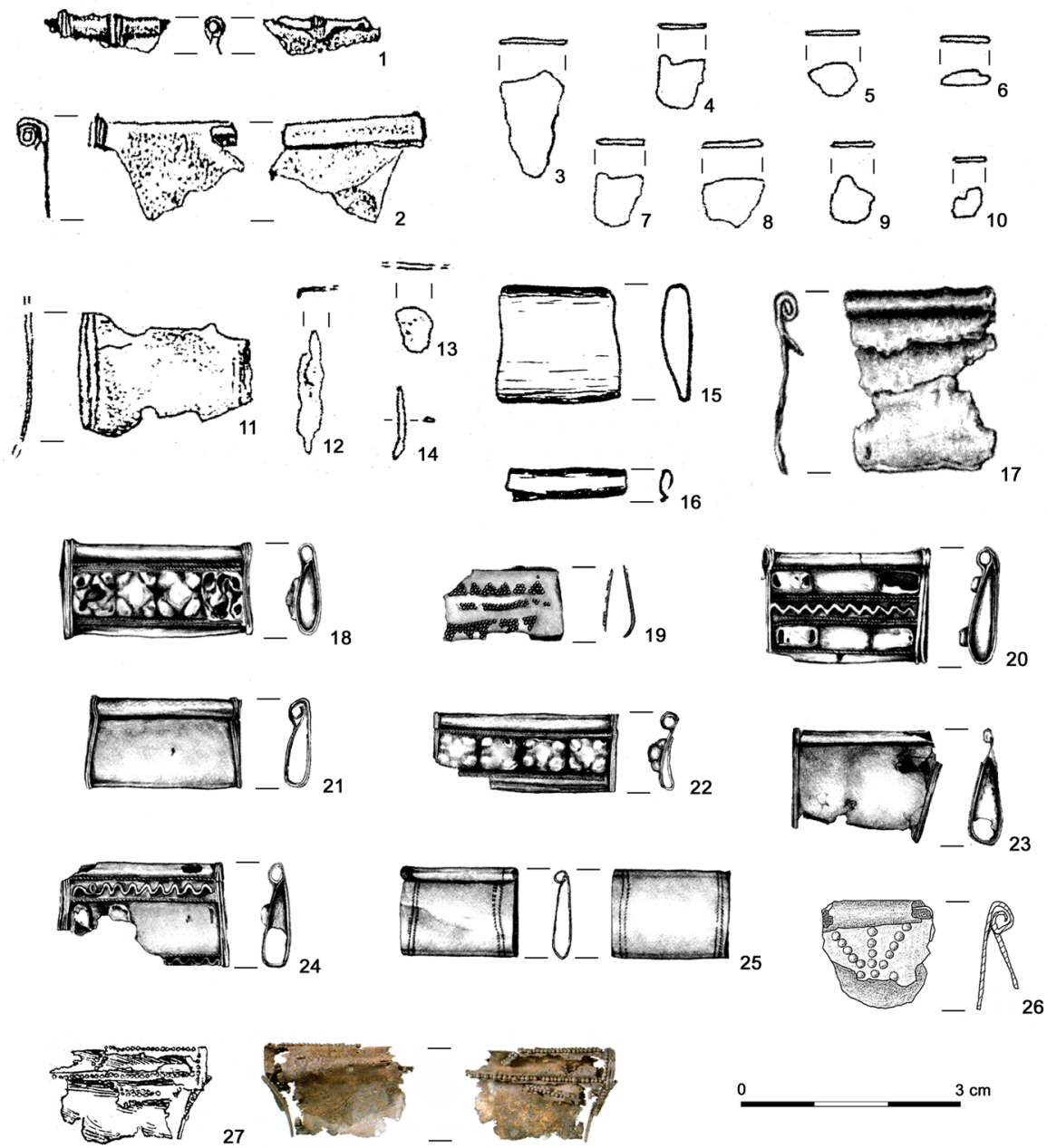

Ryc. 6. Kaptorgi typu prostokątnego z cmentarzysk. 1-14 - Giecz, grób nr 3/05 (wg Indycka 2016, ryc. 10); 15-16 - Gozdowo, grób nr 8 (wg Musianowicz 1950-1951, tabl. LXIV:3b); 17 Kałdus, stan. 1, grób nr 27/57 (wg Stawska, Weinkauf i Kozłowski 2006, tabl. 8:1a); 18-25 Kałdus, stan. 4, grób nr 13B/00 (wg Bojarski, Chudziak, Drozd, Koperkiewicz, Kozłowski i Stawska 2010, tabl. 2:a); 26 - Lubień, grób nr 36 (wg Kurasiński i Skóra 2012, tabl. XXVII:2); 27 - Lutomiersk, grób nr 22/49 (wg Nadolski, Abramowicz i Poklewski 1959, tabl. LXIV:2; Grygiel 2014, ryc. 30:10). Oprac. T. Kurasiński

w Bodzi i Pniu - po trzy, a w Lutomiersku dwa. O zróżnicowaniu można też mówić w odniesieniu do liczby egzemplarzy w poszczególnych jamach grobowych. Najwięcej kaptorg, bo aż czternaście okazów, zarejestrowano w grobie nr 62/08 z Dziekanowic. W pochówkach z Napola (nr 14) i Kałdusa, stan. 4 (nr 13B/00) stwierdzono ich odpowiednio siedem i osiem. Cztery kaptorgi odkryte zostały 
w grobie nr 32/06 w Pniu, trzy w grobie nr 6 z Parchanek, natomiast w Ciepłem (grób nr 6), Gozdowie (grób nr 8) i w Poznaniu-Śródce (grób nr 7) - po dwie. $\mathrm{W}$ pozostałych przypadkach odnotowano pojedyncze egzemplarze.

Łącznie więc zbiór kaptorg zebranych z cmentarzysk wczesnośredniowiecznych na terenie ziem polskich liczy 67 okazów, które znaleziono w 30 zespołach grobowych (uwzględniając zniszczony pochówek z Żukowa). Zdecydowaną większość (54) stanowią egzemplarze odmiany prostokątnej (ryc. 5-7) ${ }^{13}$, tylko 11 kaptorg można zaliczyć do trapezowatych (ryc. 8-10). Stan zachowania dwóch okazów (z Cedyni i Poddębic) uniemożliwia wiarygodne określenie pierwotnej formy (ryc. 11) ${ }^{14}$. O ile do grobu okazy prostokątne mogły być składane w większej liczbie egzemplarzy, o tyle trapezowate występowały pojedynczo, z wyjątkiem dwóch (?) okazów dziekanowickich z grobu nr 106/05. Tylko raz - w Dziekanowicach (grób nr 62/08) - obydwa typy kaptorg znalazły się we wspólnej jamie grobowej, w której jednej zawieszce trapezowatej towarzyszyło 13 okazów prostokątnych.

Można zatem stwierdzić, że pod względem typologicznym egzemplarze z Radomia reprezentują dominującą grupę kaptorg pochodzących z cmentarzysk. Potwierdzają tym samym fakt preferowania określonego rodzaju zawieszek, z którymi chowano zmarłych.

Biorąc natomiast pod uwagę skład chemiczny, opisywane okazy odbiegają od innych znanych okazów z ziem polskich, przy czym trzeba pamiętać o skromnej bazie porównawczej złożonej z ogólnie dostępnych ekspertyz surowcowych ${ }^{15}$ (w większości zabytki zostały określone na podstawie oglądu makroskopowego ${ }^{16}$ ). Wiadomo, że kaptorgi wykonywano przede wszystkim ze srebra i stopu miedzi,

13 Wątpliwości budzi trapezowata forma przypisywana zachowanemu we fragmencie okazowi z grobu nr 22/49 z Lutomierska (zob. ryc. 6:27) (tak Jażdżewski 1949, s. 138). Autorzy książkowego opracowania tego cmentarzyska, w ślad za ustaleniami R. Jakimowicza (1953, s. 125-126), skłaniają się ku włączeniu go do typu prostokątnego (Nadolski, Abramowicz i Poklewski 1959, s. 81-82), z czym należałoby się zgodzić (zob. także Kóčka-Krenz 1993, s. 85, 234, poz. 52).

${ }_{14}$ Szczątkowo zachowana kaptorga z Poddębic określona była jako trapezowata, a to na podstawie miejsca odkrycia (pod żuchwą dziecka) i z uwagi na ,prawie płaskie jej ścianki” (Wiklak 1960, s. 193). Są to jednak zbyt nikłe przesłanki, aby móc definitywnie wypowiadać się na temat typologicznego przyporządkowania tego zabytku (zob. ryc. 11:2). H. Kóčka-Krenz okaz ten zaliczyła do kaptorg prostokątnych (Kóčka-Krenz 1993, s. 86, 234, poz. 49), co również wydaje się bardzo niepewne. Daleko posunięta destrukcja kaptorgi pochodzącej z Cedyni także pozbawia nas możliwości określenia pierwotnego kształtu (zob. ryc. 11:1), mimo iż usiłuje się ją zaliczyć do typu okazów z wieczkiem - trapezowatych (Porzeziński 2006, s. 194).

15 Jeśli chodzi o okazy z cmentarzysk, dysponujemy jedynie wynikami specjalistycznych analiz zabytków z Bodzi (Hensel 2016, s. 306, 313, tab. 3.A.4), Dziekanowic (Wrzesiński 2015, s. 31, tab. 2; 2019, s. 71, tab. 6; Hensel, Wrzesińska, Kaliński, Pawlicka i Pogorzelska 2019, s. 412, 437; Pawlicka i Wrzesiński 2019, s. 465, 468) i Opola-Groszowic (Miazga, Rodak, Lucejko i Ribechini 2020, s. 544-547). Badaniom surowcowym zostały poddane też egzemplarze z grodzisk (Ostrów Lednicki - Banaszak i Tabaka 2017, s. 1200, tab. 1; Biskupin - Zawol 2015, s. 107, tab. 2), a ponadto kaptorgi odkryte w strefie przybrzeżnej wyspy na Jeziorze Zarańskim, wchodzącej w skład wczesnośredniowiecznego zespołu osadniczego w Żółtym (Kucypera 2014, s. 511, tab. A2.2, poz. 8-9).

${ }^{16} \mathrm{Na}$ tej podstawie stwierdzono ślady złocenia na wewnętrznej stronie blachy kaptorgi strzemieszyckiej (Marciniak 1960, s. 170; Tokaj 2009, s. 241-242). 


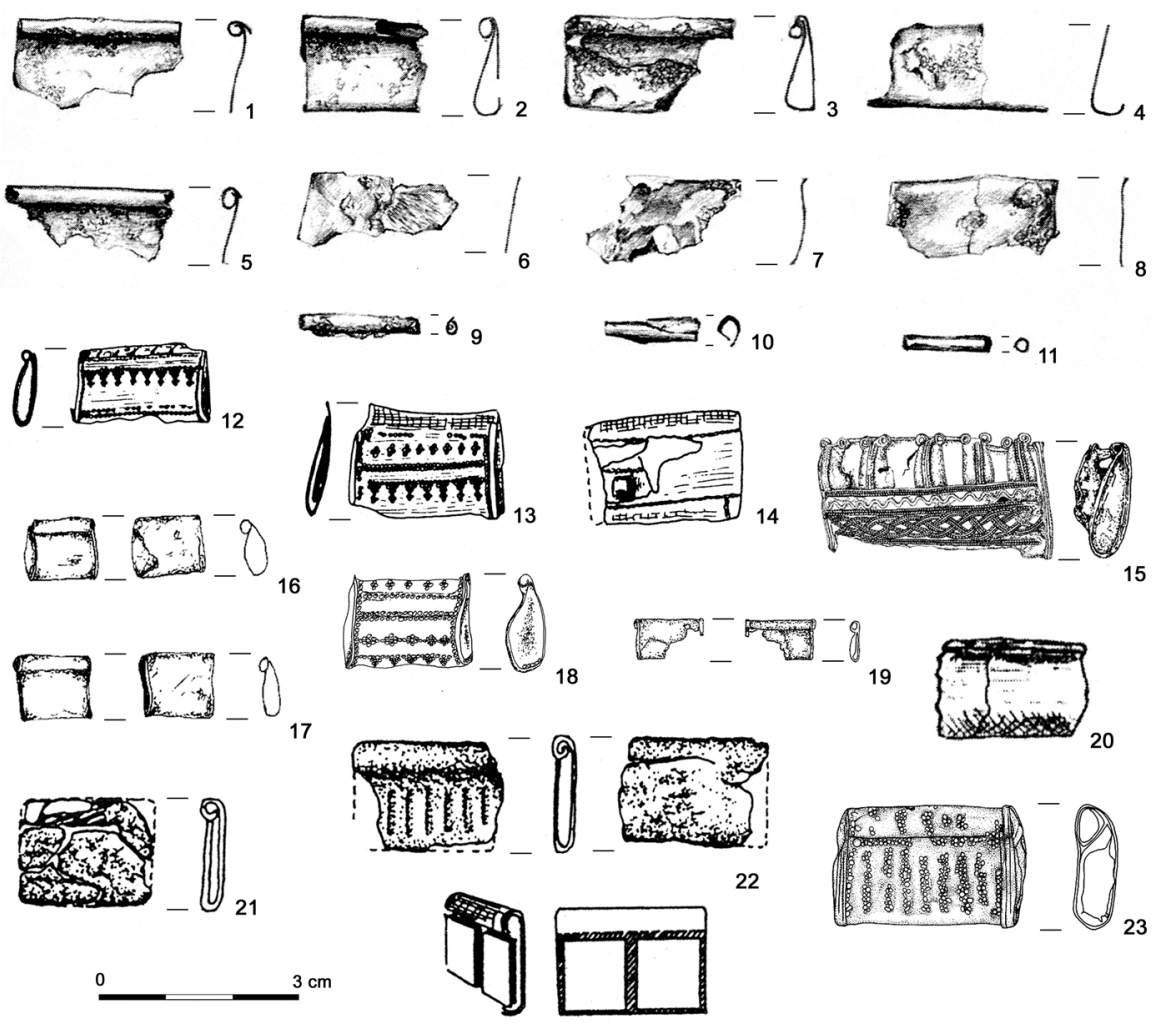

Ryc. 7. Kaptorgi typu prostokątnego z cmentarzysk. 1-11 - Napole, grób nr 14 (wg Bojarski 2014, ryc. 3:h); 12-14 - Parchanki, grób nr 6 (wg Kóčka-Krenz 1995, ryc. 13-14); 15-17 Pień, grób nr 32/06 (Błaszczyk, Drozd-Lipińska i Poliński 2020, tabl. 12:c1); 18 - Pień, grób nr 57/07 (Błaszczyk, Drozd-Lipińska i Poliński 2020, tabl. 25:f); 19 - Pień, grób nr 69/09 (Drozd, Janowski i Poliński 2011, ryc. 5:b); 20 - Poznań-Sołacz, grób nr 9 (wg Kurnatowska i Kara 2005, ryc. 3:6); 21-22 - Poznań-Śródka, grób nr 7 (wg Kóčka-Krenz, Pawlak i Sikorski 1995, ryc. 3:13-14); 23 - Żukowo, znalezisko „luźne” (wg Cichońska 2017, ryc. 2:3).

Oprac. T. Kurasiński

jakkolwiek znane są także egzemplarze z cyny, żelaza i złota. Zdarzało się, że tak jak w Czechach - łączono różne surowce: brąz i żelazo lub metal (żelazo, brąz) i materiał organiczny (Profantová 2013, s. 36; Macháček, Dresler, Přichystalová i Sládek 2016, s. 109; Frolíková, Ottenwelter i Barčáková 2020, s. 99).

Wśród uwzględnionych w niniejszej pracy kaptorg przeważają okazy srebrne i ze stopu miedzi. Tych ostatnich (zgodnie z aktualnie dostępnymi danymi) jest 17, z czego 14 to okazy prostokątne (Gozdowo, Kałdus, stan. 1, Lubień, Napole, Poznań-Sołacz, Poznań-Śródka), jedna trapezowata (Lutomiersk, grób nr 10/49) i dwie nieokreślone (Cedynia, Poddębice). Znacznie więcej pozyskano kaptorg srebrnych, 
wśród których mamy 44 egzemplarze (36 prostokątnych i osiem trapezowatych). Jak nadmieniono, zawieszki radomskie powstały z blaszki mosiężnej, o dość znacznej zawartości cynku (tab. 1). Można je zestawić jedynie z kaptorgami z Dziekanowic (groby $\mathrm{nr} 7 / 96$ - dwa egzemplarze prostokątne i $\mathrm{nr}$ 28/01 - jeden egzemplarz trapezowaty), Opola-Groszowic (grób nr 38 - jeden egzemplarz trapezowaty) i Żółtego (dwa egzemplarze prostokątne) również wykonanymi z tego stopu (zawartość Zn odpowiednio $12,07 \%, 12,57 \%, 19,12 \%, 18,4 \%, 33,1 \%$ i $22,7 \%)^{17}$.

Tabela 1. Skład chemiczny kaptorg z grobu nr 62 w Radomiu

\begin{tabular}{|c|c|c|c|c|c|c|c|c|c|c|c|c|c|c|c|c|}
\hline \multirow{2}{*}{ Zabytek } & $\mathrm{Cu}$ & $\mathrm{Al}$ & $\mathrm{Si}$ & $\mathrm{Ti}$ & $\mathrm{Cr}$ & Mn & $\mathrm{Fe}$ & $\mathrm{Ni}$ & $\mathrm{Zn}$ & As & $\mathrm{Ag}$ & $\mathrm{Sn}$ & $\mathrm{Sb}$ & $\mathrm{Pb}$ & S & $\mathrm{Au}$ \\
\hline & \multicolumn{16}{|c|}{$\%$ wagowe } \\
\hline $\begin{array}{l}\text { Kaptorga (nr inw. } \\
\text { MR.A.819c/181/66) }\end{array}$ & 68,58 & 0,09 & 0 & 0 & 0 & 0 & 0,1 & 0,11 & 25,73 & 0 & 0 & 1,68 & 0 & 3,7 & 0 & 0 \\
\hline $\begin{array}{l}\text { Kaptorga (nr inw. } \\
\text { MR.A.819c/191/66) }\end{array}$ & 67,27 & 0,13 & 0,1 & 0 & 0 & 0 & 0,41 & 0 & 19,24 & 0 & 0,39 & 2,97 & 0 & 9,28 & 0 & 0,21 \\
\hline
\end{tabular}

Łączenie miedzi z innymi składnikami stopowymi wpływa nie tylko na parametry fizyczne i mechaniczne przedmiotu, ale też na efekty wizualne. Wraz ze wzrostem zawartości cynku barwa stopu miedzi zmienia się na złotą. Dochodzi do tego w momencie, gdy jest już go około 10\% (Mecking 2018-2019, s. 197-198; Hensel, Wrzesińska, Kaliński, Pawlicka i Pogorzelska 2019, s. 393). Badania prowadzone pod tym kątem wykazują, że domieszka ołowiu nie wpływa znacząco na zabarwienie „czystego" mosiądzu, gdyż zależy ono głównie od zawartości cynku (Mecking 2018-2019, s. 199). Duży stopień zmienności kolorystycznej wykazuje za to konglomerat cynkowo-cynowo-miedziany. Badania pokazują, że chcąc uzyskać złoty odcień w stopie, zawartość cyny nie powinna przekraczać $7 \%$ przy zawartości cynku sięgającej około 20\% (Mecking 2018-2019, s. 199-201). Niewielkie zmiany barwy $\mathrm{w}$ takim trójskładnikowym układzie zauważono przy udziale ołowiu do 8\%. Mosiądz cynowo-ołowiowy można określić jedynie w przybliżeniu, gdyż o jego kolorze decydują głównie składniki stopu Sn-Zn, w mniejszym zaś stopniu samego ołowiu (Mecking 2018-2019, s. 199-201, 203).

Powołując się na powyższe ustalenia, należy się spodziewać, iż zawieszki z Radomia miały barwę najbardziej zbliżoną do złotej ${ }^{18}$, choć zważywszy na nieco inny skład chemiczny, mogły w jakimś zakresie różnić się od siebie odcieniem. Wynika

\footnotetext{
17 Zob. przyp. 15.

${ }^{18} \mathrm{Na}$ kolor stopu miedzi wpływać mogły także inne pierwiastki, jak arsen, antymon, nikiel czy srebro (Mödlinger, Kuijpers, Braekmans i Berger 2017; Mecking 2018-2019, s. 201-203). W naszym
} 

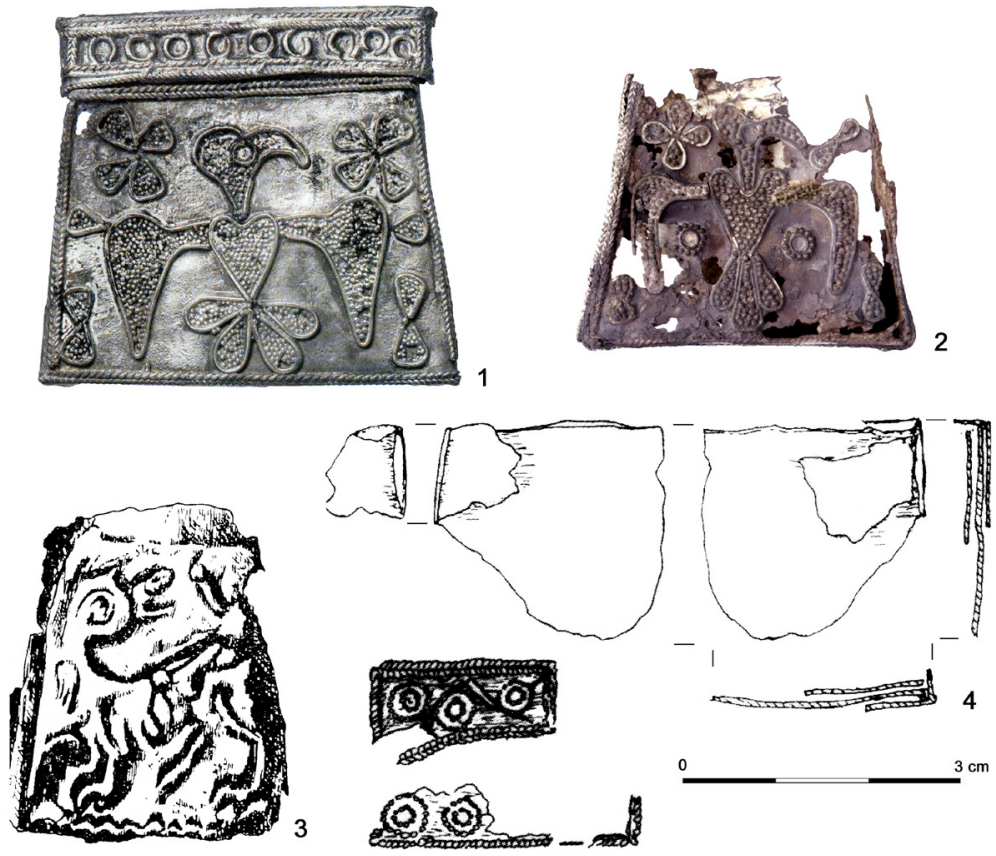

Ryc. 8. Kaptorgi typu trapezowatego z cmentarzysk. 1 - Bodzia, grób nr E72 (wg Duczko 2016, ryc. 3.4.7); 2 - Bodzia, grób nr E864/II (wg Duczko 2016, ryc. 3.4.8); 3 - Dąbrowa Górnicza-Strzemieszyc Wielkie, grób nr 58 (wg Marciniak 1960, tabl. V:13); 4 - Dziekanowice, grób nr 106/05 (wg Wrzesiński [red.] 2019, tabl. 134:4-5). Oprac. T. Kurasiński

z tego, że przy produkcji zawieszek z Radomia za sprawą właściwego doboru jakościowo-ilościowego surowców i metalurgicznej obróbki rzemieślnik starał się nadać tym wyrobom nie tylko odpowiednie cechy fizyczne, ale w równym stopniu kierowały nim względy estetyczne. Osiągnięty efekt kolorystyczny w postaci optycznej imitacji złota ,uszlachetniał” kaptorgi, upodabniając je do przedmiotów wykonanych z najcenniejszych z kruszców.

Problematyczną kwestię stanowi brak bezpośrednich analogii dla ornamentu w postaci rzędowo ułożonych guzkowatych rozetek. Wśród materiałów nekropolicznych najbliższy odpowiednik to repusowane guzki widoczne na trzech kaptorgach odkrytych w grobie nr 62/08 na cmentarzysku w Dziekanowicach (ryc. 5:2, 4, 8) (Wrzesiński 2015, ryc. 16-17, 24; Strobin 2015, s. 123-124, 134, ryc. 2-3, 12) i dwóch z Kałdusa, stan. 4 z grobu nr 13B/00 (ryc. 6:18, 22) (Chudziak 2001, s. 74, ryc. 7:b). Są to okazy srebrne odmiany prostokątnej. Wytłaczane guzki

jednak przypadku ich nikła zawartość (lub zupełny brak) sprawiają, że dla omawianego problemu są pozbawione znaczenia. 
tworzące rozety znajdują się na jeszcze jednej kaptordze, tym razem trapezowatej, z cmentarzyska dziekanowickiego (grób nr 28/01). Są one jednak innego kształtu (ryc. 9:1). Motyw ten widnieje również na trapezowatych kaptorgach z Bodzi (groby nr E864/II i E72) (ryc. 8:1-2), przy czym sporządzono je w odmiennej technice - z wykorzystaniem granulacji i filigranu (Zawol 2018, s. 479, ryc. 18).

Największe podobieństwo wykazują jednak wzmiankowane już zawieszki zalegające w nawarstwieniach związanych z przybrzeżnymi konstrukcjami drewnianymi wyspy na Jeziorze Zarańskim (Źółte), datowanymi dendrochronologicznie na 2. połowę XI wieku. Na zawieszkach tych zasadniczy wątek ornamentacyjny stanowią ułożone w rzędzie, tłoczone pięcioelementowe guzki (ryc. 13) (Kaźmierczak i Hildebrandt 2014, s. 261-262, ryc. 6.128:a-b). Zapewne w podobnej technice wykonane zostały zdobienia na kapsułkach radomskich, lecz zły stan ich zachowania nie pozwala wypowiadać się w tej materii w sposób ostateczny. Warto przypomnieć, że okazy z Żółtego również wykonano z mosiądzu.

Kontekst odkrycia kaptorg radomskich wykazuje większą zgodność z wcześniej dostrzeżonymi prawidłowościami dla tego rodzaju wytworów, dotyczącymi przede wszystkim lokalizacji w grobie oraz charakterystyki samego pochówku.

Jak dowodzą analizy antropologiczne, z rozpatrywanymi kapsułkami chowano wyłącznie kobiety, zmarłe w różnym wieku, przeważnie przed osiągnięciem 35 roku życia (Adultus), choć niektóre z nich mogły być starsze (np. Opole-Groszowice, Pień, grób nr 32/06). Stosunkowo częste były pochówki dziecięce (Cedynia, Dziekanowice - groby nr 7/96, 28/01 i 106/05, Napole, Pien - grób nr 57/07, Poddębice). Szczątki kostne należały do dzieci o zróżnicowanym wieku. Najmłodsze z nich (około 1,5-2 lat) spoczęło w grobie nr 7 w Napolu (Bojarski 2014, s. 176). Jest to o tyle istotna obserwacja, iż bardzo sporadycznie na wczesnośredniowiecznych cmentarzyskach z ziem polskich zdarzało się, aby przed ukończeniem 3-4 roku życia zmarłym przysługiwało wyposażenie pośmiertne (zob. Kurasiński 2010, s. 329; Kurasiński i Skóra 2015, s. 47). Z kaptorgami pochowano także osobnika młodocianego (około 14-15-letniego), którego szkielet znajdował się w grobie nr 7 w Poznaniu-Śródce (Wrzesińska 1999, s. 125). Pomimo braku możliwości określenia płci osób małoletnich charakter wyposażenia, zwłaszcza obecność ozdób, sugeruje płeć żeńską. $Z$ regułą odkrywania kaptorg w grobach kobiecych i dziecięcych mamy również do czynienia na cmentarzyskach czeskich i morawskich (Štefan 2004, tab. 6; Ungerman 2007, s. 229; Profantová i Šilhová 2010; Profantová, Špaček i Novotná 2011; Macháček, Dresler, Přichystalová i Sládek 2016, s. 109; Profantová i Daněček 2017; Frolíková, Ottenwelter i Barčáková 2020).

Miejsce zalegania kaptorg względem szkieletu (górne partie klatki piersiowej i bezpośrednie okolice czaszki ${ }^{19}$ ) stanowi odzwierciedlenie sposobu noszenia tych

${ }^{19}$ W przypadku Dziekanowic (grób nr 7/96) jedna z kaptorg znajdowała się w pewnym oddaleniu od czaszki, na skraju jamy grobowej, z kolei w Poznaniu-Sródce (grób nr 7) zawieszkę zlokalizowano w pobliżu miednicy, do czego jeszcze wrócimy. 

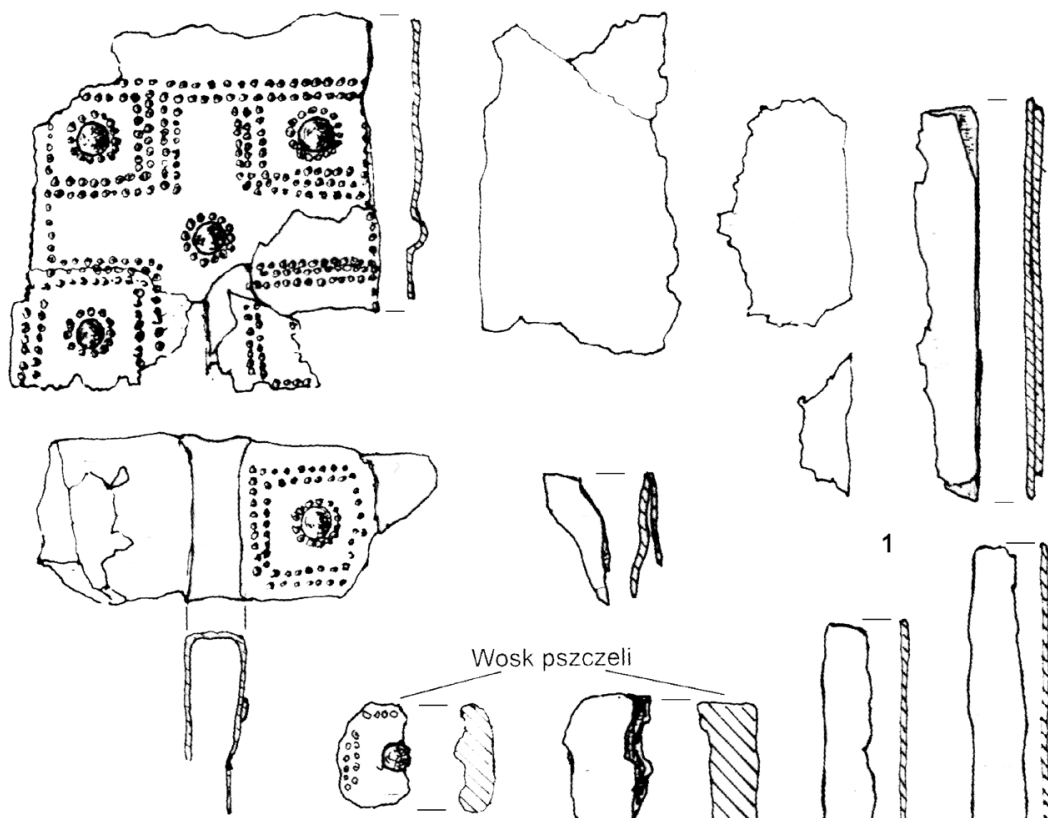

Wosk pszczeli
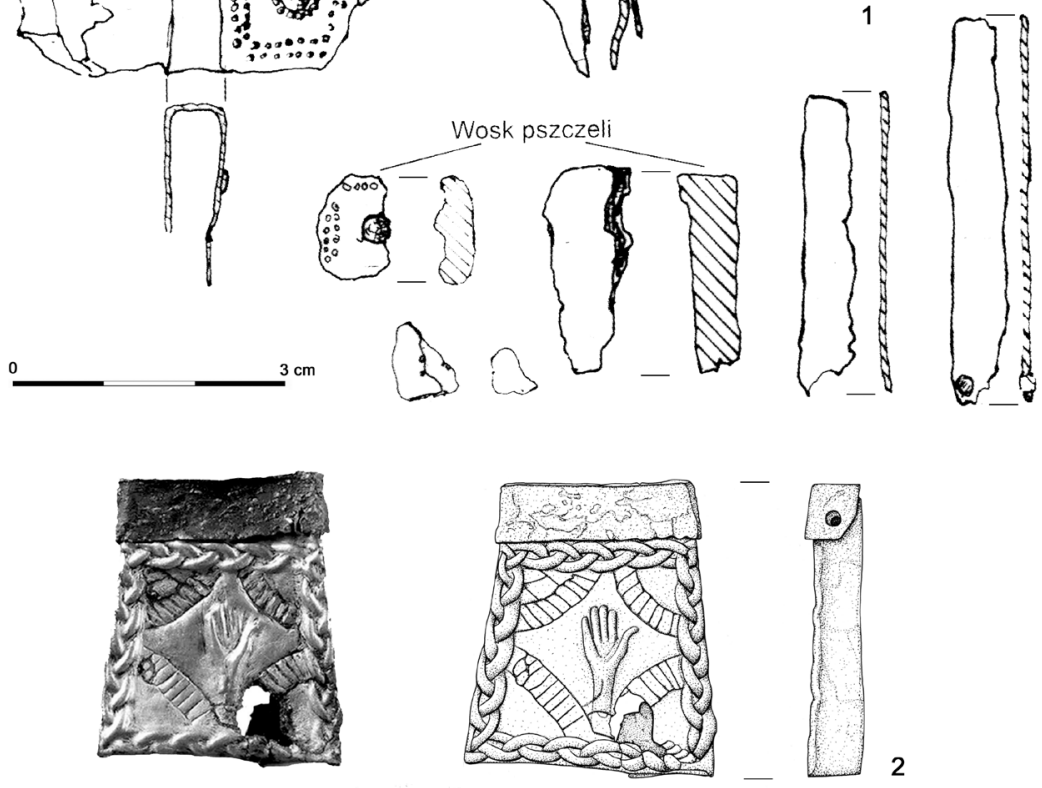

Ryc. 9. Kaptorgi typu trapezowatego z cmentarzysk. 1 - Dziekanowice, grób nr 28/01 (wg Wrzesiński [red.] 2019, tabl. 73:12); 2 - Dziekanowice, grób nr 62/08 (wg Wrzesiński [red.] 2019, ryc. 23, tabl. 169:53). Oprac. T. Kurasiński

przedmiotów - wieszano je na szyi bądź jako samodzielne zawieszki, bądź - najczęściej - w zespole z innymi ozdobami (paciorkami z metalu, szkła, kamieni półszlachetnych i bursztynu) jako element kolii (zob. Sztyber 2010, s. 46-47; por. Štefan 2004). Niekiedy, jak w przypadku grobów nr 62/08 z Dziekanowic, nr 13B/00 z Kałdusa, stan. 4 i nr 14 z Napola, liczniejszy zestaw kaptorg wskazuje, że stanowiły one podstawową część naszyjnika (zob. ryc. 14). W ostatnim 
z wymienionych pochówków stwierdzono obecność dwóch kolii. Jedna zawierała nanizane paciorki, druga zaś złożona była z siedmiu prostokątnych zawieszek (Bojarski 2014, s. 177). Z kolei na kolię z grobu nr 32/06 w Pniu przypuszczalnie składały się cztery sznury spięte dwuelementową klamrą, z których jeden zawierał kaptorgi i 12 srebrnych paciorków (Drozd, Janowski i Poliński 2009, s. 354).

Egzemplarze radomskie potwierdzają te obserwacje. Wraz z paciorkami szklanymi noszone były na szyi, podobnie jak w przypadku Ciepłego (grób $\mathrm{nr}$ 6) i Gozdowie (grób nr 8), gdzie również odnotowano kolie utworzone z paciorków i dwóch prostokątnych kaptorg. Dwa okazy (stop miedzi) tej odmiany zostały znalezione też w grobie $\mathrm{nr} 7 \mathrm{z}$ Poznania-Śródki, przy czym nie towarzyszyły im inne ozdoby szyi.

Trapezowata kaptorga odkryta w grobie nr E72 w Bodzi pierwotnie zawieszona była na srebrnym łańcuszku, z którego pozostały jedynie fragmenty (Sobkowiak-Tabaka 2016, s. 75), co wydawałoby się najbardziej adekwatnym do rangi przedmiotu sposobem jego noszenia ${ }^{20}$. Szczególnie dobrze ukazuje to okaz będący częścią skarbu z 3.-4. ćwierci XI wieku odkrytego w Olbrachtówku (ryc. 15) (Czonstke i Koperkiewicz 2013, s. 226, 242, tabl. I:6; por. egzemplarze z pochówków czeskich - Frolík 2013, s. 58-59, ryc. 1/36). Częściej jednak kaptorgi wieszano na zwykłych sznurkach lub niciach, których resztki zachowały się niekiedy w rurkowatych uchwytach (odmiana prostokątna) lub otworach (odmiana trapezowata). Stwierdzono je nie tylko przy egzemplarzu z Radomia, ale też z Dziekanowic, grób nr 62/08 (Sikorski 2015; 2019, s. 329, 332, 335-336, ryc. 9), Opola-Groszowic (Urbańska 1959, s. 177, 183; Miazga, Rodak, Lucejko i Ribechini 2020, s. 547-548, ryc. 7-8), Poznania-Śródki (Kóčka-Krenz, Pawlak i Sikorski 1995, s. 290-291; Pawlak i Sikorski 1995, s. 133-135; Pawlak i Pawlak 2015, s. 72) i Parchanek (Kóčka-Krenz 1995, s. 277). Sznurki lub nici wykonano z surowca pochodzenia roślinnego. W niektórych przypadkach analiza pozwoliła doprecyzować, iż tak jak w Radomiu chodzi o włókna lniane (Poznań-Śródka, Opole-Groszowice $)^{21}$.

Trudno rozstrzygnąć, czy kaptorgi w powyższy sposób używane były na co dzień, czy wynikało to tylko z doraźnej potrzeby związanej z pochówkiem. Wolno założyć, iż najmłodszym dzieciom nie wkładano takich naszyjników za życia. Był to raczej dar grobowy od rodziców lub innych krewnych, a zarazem reprezentacyjny element wystroju pośmiertnego (Frolíková, Ottenwelter i Barčáková 2020, s. 286). Na okazjonalne zastosowanie sznurka w celach sepulkralnych może wskazywać pochówek z Poznania-Śródki. Był on na tyle nietrwały, że uległ szybkiemu zerwaniu, może już w czasie pogrzebu, co spowodowało osunięcie się jednej z kaptorg w stronę miednicy (Kóčka-Krenz, Pawlak i Sikorski 1995, s. 291; Pawlak

${ }^{20}$ Łańcuszek (mosiądz) złożony z ogniw o średnicy do $0,7 \mathrm{~cm}$ odkryto także w grobie $\mathrm{nr}$ 28/01 w Dziekanowicach, ale była to niezależna ozdoba szyi (Wrzesiński 2019, s. 70).

${ }^{21}$ Dla porównania z cmentarzyska w Stehelčeves (Czechy) pochodzi kaptorga zawieszona na sznurku konopnym (Profantová i Šilhová 2010, s. 287, ryc. 17:1a-b). 

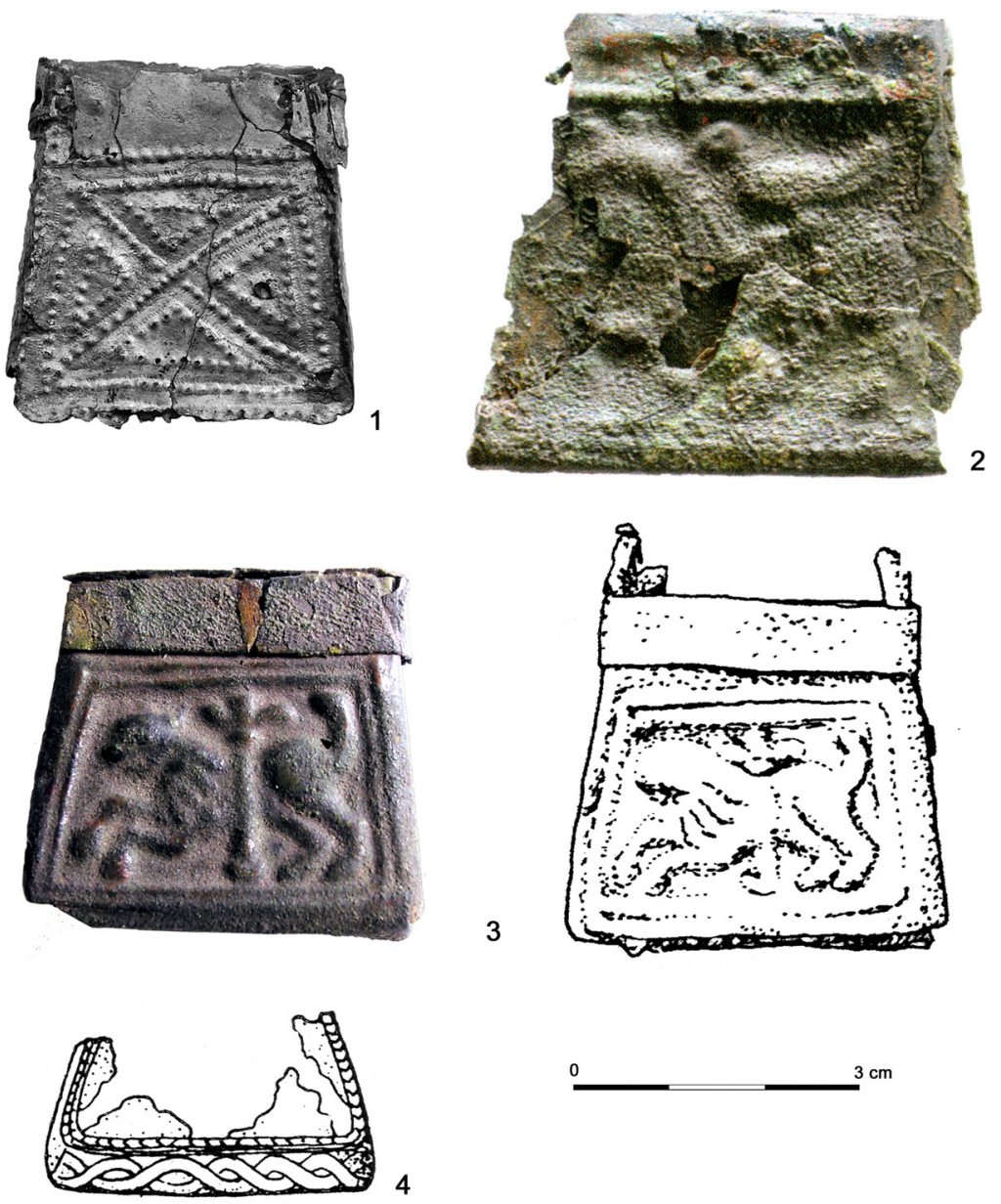

Ryc. 10. Kaptorgi typu trapezowatego z cmentarzysk. 1 - Kwiatków, grób nr 282 (wg Zawol 2018, ryc. 25); 2 - Lutomiersk, grób nr 10/41 (wg Grygiel 2014, ryc. 38:2); 3 - Opole-Groszowice, grób nr 38 (wg Wachowski 1975, ryc. 18:48; Holc 2005, ryc. na s. 106); 4 - Sandomierz, grób nr 7 (wg Gąssowski 1969, ryc. 69:a). Oprac. T. Kurasiński

i Pawlak 2015, s. 72). To właśnie w „uszku” tego okazu natrafiono na włókna Iniane (Pawlak i Sikorski 1995, s. 134). Przypuszczalnie w takich wypadkach końce sznurka po prostu ze sobą związywano.

$\mathrm{Z}$ innym rozwiązaniem spotykamy się w grobach z Ciepłego (nr 6), Kałdusa (nr 13B/00) i Pnia (nr 32 i 57), gdzie do spięcia kolii złożonej z prostokątnych kapsułek ze srebra oraz paciorków posłużyły owalne klamry ze srebra. Zastanawiać 
przy tym może fakt, iż w dwóch przypadkach były one zdekompletowane. W grobie $\mathrm{nr} 57 \mathrm{z}$ Pnia zachowała się bowiem tylko połowa pierwotnego układu dwuelementowego (Błaszczyk 2020a, s. 110-111, ryc. 57:c), podobnie w Kałdusie (Chudziak 2001, s. 76, ryc. 7:a; Bojarski, Chudziak, Drozd, Koperkiewicz, Kozłowski i Stawska 2010, s. 441, tabl. 2:b) ${ }^{22}$. Czy to również wynikało z kontekstu grobowego i nieprzywiązywania wagi do należytego zapięcia kolii? $\mathrm{Na}$ obecnym etapie zgromadzonej wiedzy pytanie to musi pozostać bez odpowiedzi.

\section{KWESTIE GENETYCZNO-KULTUROWE I CHRONOLOGICZNE}

W literaturze przedmiotu szeroko dyskutowaną kwestią jest pochodzenie omawianych zawieszek, a także samej idei ich używania.

Rozmaicie uformowane pojemniczki czy kapsułki o charakterze amuletów były szeroko rozpowszechnione w każdej właściwie kulturze i każdym momencie dziejowym, w tym także we wczesnym średniowieczu. Między V a VII wiekiem występowały one na obszarach rozciągających się od Kaukazu po Półwysep Iberyjski (np. Schellhas 1994; Wamers 1995; Vida 1995; 2009; Milinković 2013). Używano ich również w północnej Europie (np. Duczko 1985, s. 63-66; Heyerdahl-Larsen 1982; Koktvedgaard Zeiten 1997, s. 31). Często przyjmowały one kształt tarczowaty lub cylindryczny, toteż ich typologiczno-formalny związek z kaptorgami nie rysuje się jednoznacznie (zob. Sztyber 2008, s. 284), choć sama idea przypisywania mocy tym przedmiotom, zwłaszcza jeśli chodzi o ich zawartość, wykazuje już wiele podobieństw (z powołaniem na literaturę Ungerman 2007, s. 230).

Warto też zasygnalizować istnienie grupy czworobocznych zawieszek w postaci zminiaturyzowanej księgi-kodeksu (buchförmiger Anhänger), do złudzenia przypominających omawiane w niniejszej pracy wyroby. Są to pojedyncze znaleziska, datowane na VI-IX wiek, odnotowane w Szwecji, Niemczech i na Morawach. Podobnie jak kaptorgi, również te zabytki interpretowane są jako amulety, których funkcja zasadzała się na treści świętych ksiąg - Starego i Nowego Testamentu. Chroniły swych właścicieli przed demonami i chorobami, pomagały znosić codzienne troski (Corsten 1991; Štefanovičová 2000) ${ }^{23}$. Jak jednak sądzą inni badacze, w tej grupie przedmiotów znajdują się też ozdobne okucia pasa, pozostające raczej bez związku z formą kodeksową (Klanica 2010).

Powszechnie uważa się, iż kaptorgi prostokątne są wytworem złotnictwa słowiańskiego, za czym przemawiać mają zwłaszcza charakterystyczne dla tego kręgu

${ }^{22}$ Brak w takich wypadkach pozostałości łańcuszka sugeruje wszakże, że elementy te nanizane były na nitkę lub sznurek (por. Kóčka-Krenz 1993, s. 103).

${ }^{23}$ „Ihrer Funktion nach sind sie christliche Amulette, die sowohl von Männern als auch von Frauen getragen wurden und von denen sich die Träger Schutz und Hilfe erwarteten. Diese Funktion übernahmen sie von den bereits bestehenden Büchern christlichen Inhalt (Hl. Schrift oder Evangelium) und ahmen auch rein äußerlich Form und Exklusivität ihrer Vorbilder nach” (Corsten 1991, s. 188). 


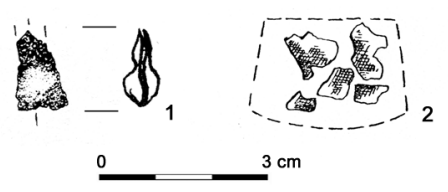

Ryc. 11. Kaptorgi nieokreślone. 1 - Cedynia, grób nr 30 (wg Porzeziński 2006, tabl. XXXVII:i); 2 - Poddębice, grób nr 9 (wg Wiklak 1960, tabl. XLVI:2). Oprac. T. Kurasiński

kulturowego motywy zdobnicze (Tabaczyński 1958, s. 22; Sztyber 2010, s. 47). W przypadku ziem polskich $\mathrm{w}$ ich rozpowszechnieniu niekiedy wskazuje się na pośrednictwo Czech (Kostrzewski 1962, s. 199; Stattler 1966, s. 240). Bardziej złożona sytuacja określa kaptorgi trapezowate, dla których zarysowały się dwie podstawowe koncepcje (zob. Sztyber 2010, s. 48, z powołaniem na podstawową literaturę). W myśl jednej są one wywodzone ze Wschodu, jako element szczególnie reprezentatywny przede wszystkim dla arabskiego rzemiosła. Według drugiej, dla tego typu kapsułek istnieją pierwowzory w postaci zachodnioeuropejskich relikwiarzy, lokując je tym samym w sferze oddziaływań sztuki karolińsko-ottońskiej24. Dodać należy, że również w tym wypadku obecność kaptorg na terytorium dzisiejszej Polski wiązana jest z czeskim oddziaływaniem w zakresie złotniczej wytwórczości (Tabaczyński 1958, s. 25; Abramowicz 1962, s. 105; Kóčka-Krenz 1993, s. 155-156; Zawol 2013, s. 123; Duczko 2018, s. 537; na szerszym tle Matla 2020, s. 181-185) ${ }^{25}$. Dostrzegana jest także obecność ruskich zapożyczeń, jak w przypadku okazów z Bodzi zdobionych wyobrażeniem orła (Duczko 2016, s. 145). Niezależnie od kierunku (lub kierunków) pochodzenia inspiracji bądź ewentualnego napływu importów rodzimą wytwórczość okazów trapezowatych potwierdza wzmiankowana wcześniej patryca z cmentarzyska w Brześciu Kujawskim. Widoczny jest na niej motyw dwóch ptasio- lub gadziopodobnych stworzeń (ryc. 12). Sam zabytek genetycznie wiązać się może ze sztuką romańską (Abramowicz 1962, s. 105), wskazywane są także impulsy wschodnie (Gąssowska 1979, s. 138).

Pojawia się tu także kwestia, w jakim stopniu i czy w ogóle kaptorgi dają się traktować jako identyfikator etnicznej tożsamości zmarłych kobiet. Zważywszy na

${ }^{24} \mathrm{~W}$ tym środowisku dochodziło do przejmowania i twórczej adaptacji wschodnich motywów zdobniczych (Tabaczyński 1958, s. 24).

${ }^{25}$ Niekiedy jednak, jak w przypadku trapezowatej kaptorgi z Dobroměřic z odwróconymi względem siebie wizerunkami zwierząt, można mówić o „północnym” kierunku napływu. Okaz ten zapewne wykonany został w południowej części basenu Morza Bałtyckiego przez skandynawskiego lub słowiańskiego rzemieślnika, zaznajomionego z nordycką wytwórczością (Košnar 1991, s. 69-71, ryc. 7:2). Wolno liczyć się wszakże z sytuacją przybycia do Czech rzemieślnika, który na miejscu stosował obce wzornictwo (Profantová i Šilhová 2010, s. 304). 
to, że ten rodzaj zawieszek wykazuje silne powiązania ze strefą osadniczą zajmowaną przez Słowian, można spodziewać się pogrzebanych przedstawicielek tego właśnie etnosu. Rzecz jednak może okazać się bardziej złożona. Problem zasygnalizował J. Sikora, akcentując relatywną rzadkość występowania tych zawieszek oraz ich bliski związek z „obcymi” kulturowo komorowymi konstrukcjami grobowymi (Sikora 2012, s. 339, przyp. 16), jakkolwiek o takiej formie grobu decydował raczej status zmarłego aniżeli jego etniczna przynależność, o czym zresztą przekonuje sam zacytowany badacz (Sikora 2013a; 2013b; zob. także Janowski 2015, s. 73-80). Dodajmy do tego wyniki badań izotopowych pochówka E864/II z Bodzi, wskazujące, że kobieta $\mathrm{z}$ tego grobu ma zapewne pochodzenie pozamiejscowe (ruskie?) (Price i Frei 2016, s. 435; Błaszczyk 2015-2016, s. 144, 150-151)26. Oczywiście, nie oznacza to automatycznie, że przedmiot także musi mieć obcą proweniencję, aczkolwiek uprawdopodabnia taką tezę, zważywszy na to, że kaptorga $\mathrm{z}$ tego grobu wykazuje cechy wzornictwa pozamiejscowego. Z kolei odwołując się do źródeł pisanych, warto przypomnieć fragment relacji Ibn Fadlāna (X wiek), iż każda z kobiet ludu ar-Rūsīja, identyfikowanego najczęściej ze szwedzkimi przybyszami zamieszkującymi tereny północnej Rusi, „ma na piersi umocowane puzderko czy to z żelaza, czy ze srebra, z miedzi, czy [wreszcie] ze złota, stosownie do majątku jej męża i rozmiarów tegoż [majątku]. Przy każdym puzderku jest pierścień, do którego przymocowany jest nóż, również [zawieszony] na piersiach" (Ibn Fadlān 1985, s. 109). Zawieszki te interpretowane są jako kaptorgi (Ibn Fadlān 1985, komentarz na s. 196, przyp. 449; zob. także Dzieduszycki 1995, s. 38; Zhilina 2002, s. 175-177; Lewicka-Rajewska 2004, s. 138). Jednakże z uwagi na ów „pierścien”" uważa się też, że arabski podróżnik miał na myśli okrągłe fibule, zdobione ornamentyką zwierzęcą i plecionkową, z przymocowanymi do spodniej strony uszkami, łańcuszkami lub haczykami, które służyły do zawieszenia m.in. noży (Androshchuk 2013, s. 23-25).

Nie zagłębiając się w skomplikowane zagadnienie genezy kaptorg, warto zwrócić uwagę na ich chronologię, zwłaszcza okazów typu prostokątnego, najbardziej istotnych z punktu widzenia niniejszej pracy. Do najstarszych znanych kapsułek tego rodzaju należą okazy z czeskich cmentarzysk ze Starej Kouřimi, grób nr 106b (Šolle 1959, s. 452-455, ryc. 65:1-3, 66; 1966, s. 158, 266-267, ryc. XLVI-XLVII) i Libic, grób nr 268 (Turek 1976, s. 273, tabl. 2:13; 1978, s. 122, 123; Mařík 2009, s. 130-131) - 1. ćwierć X wieku. Na szczególną uwagę zasługuje też mocno uszkodzony, niezdobiony okaz ze stopu miedzi odkryty na grodzisku w Starigardzie-Oldenburgu, w nawarstwieniach z początku IX wieku. Pozostałe kaptorgi

${ }^{26}$ Analizy mtDNA nie pozwoliły natomiast stwierdzić obcego (a już z pewnością skandynawskiego) pochodzenia osób pochowanych z kaptorgami na innych cmentarzyskach, choć warto podkreślić, iż kobiety z grobu nr 32/06 w Pniu i nr 13B z Kałdusa, stan. 4, wyróżniały się rzadko notowanymi w Europie haplogrupami (Płoszaj, Jędrychowska-Dańska, Zamerska, Drozd-Lipińska, Poliński, Janowski i Witas 2017, s. 321, 322, tab. 1; Płoszaj, Jędrychowska-Dańska, Zamerska, Lewandowska, Bojarski, Chudziak, Drozd-Lipińska, Robaszkiewicz i Witas 2020, s. 46, tab. 1). 

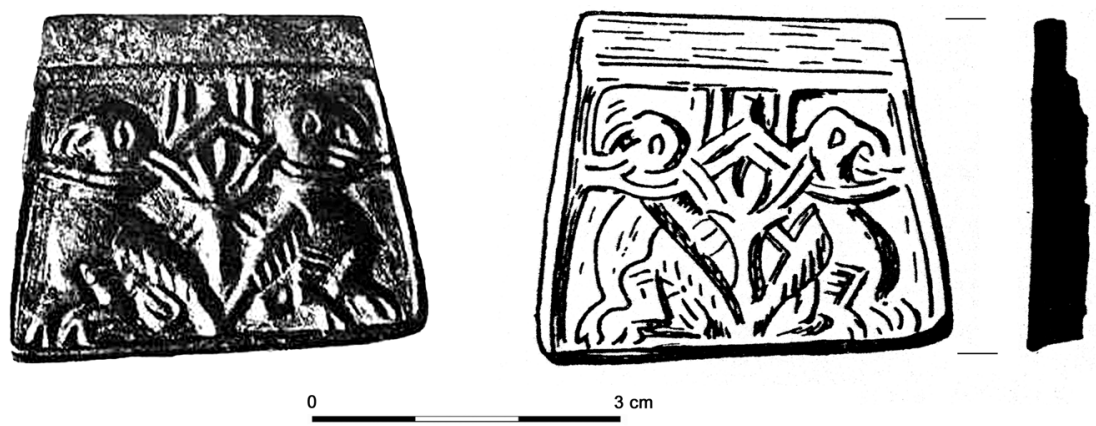

Ryc. 12. Patryca z grobu nr 160 w Brześciu Kujawskim (wg Kaszewscy 1971, tabl. VIII:12; Zawol 2015, ryc. 7). Oprac. T. Kurasiński

z tego stanowiska (4 egz.) pochodzą z początku X-początku XI wieku (Gabriel 1988, s. 181, ryc. 31:1-2). Wcześnie datowany jest także egzemplarz z grobu nr 606 w Birce, wiązany ze środowiskiem wielkomorawskim (Duczko 1985, s. 62). Z około 900 roku lub początku X wieku pochodzi okaz z południowego cmentarzyska (grób nr 875) w Haithabu (Arents i Eisenschmidt 2010a, s. 127).

Od X do końca XI wieku nastąpiło upowszechnienie kaptorg prostokątnych. Wytwarzano je głównie ze srebra z wykorzystaniem wszelkich technik dekorowania. W XII wieku zarzucono stosowanie bogatej ornamentyki. Okazy tej odmiany sporadycznie występowały jeszcze do połowy XIII wieku, o czym może świadczyć znalezisko z cmentarzyska w Gozdowie (Kóčka-Krenz 1993, s. 86; Sztyber 2010, s. 46).

Wczesne używanie kaptorg prostokątnych na ziemiach polskich potwierdzają analizy ${ }^{14} \mathrm{C}$. Pod tym kątem zbadano włókna lnu z zawieszki odkrytej w Bodzi (grób nr D148). Uzyskana data radiowęglowa (1070 $\pm 35 \mathrm{BP})$ przekłada się na przedział chronologiczny 895-1020 AD (Goslar 2016, s. 453) ${ }^{27}$. Zbliżony wiek kalendarzowy (890-1020 AD; $1095 \pm 30$ BP) mamy dla pochówka z Dziekanowic (nr 62/08). Próbkę pobrano z kości ludzkich (Wrzesiński 2015, s. 48-49, tab. 4). Potwierdza to znaleziona moneta z lat 983-1020 (Suchodolski 2015). Z kolei dla szczątków kobiety z grobu nr 13B uzyskano datę radiowęglową $1100 \pm 50 \mathrm{BP}$ (Chudziak, Bojarski i Stawska 2010b, s. 112), dającą przedział obejmujący lata 777-1023 AD (Sikora 2015, s. 135). Starszy był grób nr 3/05 z Giecza. Ze szkieletu pobrano dwie próbki, wskazujące na przedziały wieku kalendarzowego: 770-970 AD (1165 \pm 30 BP) i 780-990 AD (1135 \pm 30 BP). Do inhumacji doszło zatem w końcu X wieku (Indycka 2016, s. 236). Z bardzo zbliżonego horyzontu czasowego pochodzi grób nr 22 z Lutomierska - 778-962 AD (1210 \pm 30 BP - na podstawie kości ludzkich) (Grygiel 2014, s. 737, ryc. 42; Sikora 2015, s. 157),

27 Wszystkie podane w niniejszej pracy daty kalendarzowe zostały wyznaczone przy prawdopodobieństwie wynoszącym 95,4\%. 


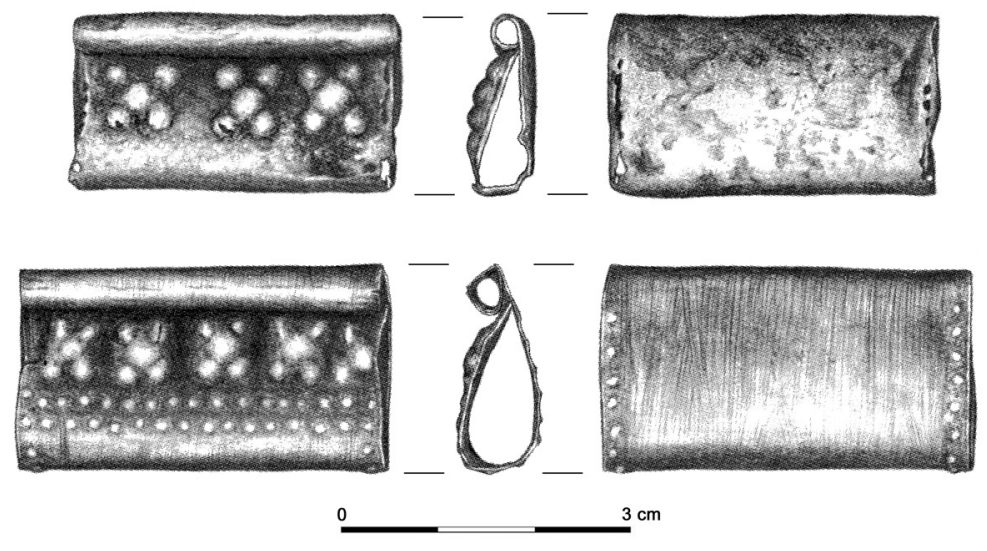

Ryc. 13. Kaptorgi z Żółtego (wg Kaźmierczak i Hildebrandt 2014, ryc. 6.128:a-b). Oprac. T. Kurasiński

aczkolwiek w tym przypadku nie ma absolutnej pewności co do prostokątnego kształtu kaptorgi. W uzupełnieniu można dodać, iż z końca X lub 1. połowy XI wieku pochodzi pochówek z Parchanek (Kóčka-Krenz 1995, s. 278). Podobną chronologię (2. połowa $\mathrm{X}$ - początek XI wieku) przypisuje się grobom komorowym z Pnia (Drozd, Janowski i Poliński 2009, s. 355; Błaszczyk 2020b, s. 146).

We wszystkich wymienionych obiektach zostały zdepononowane kaptorgi srebrne, w większości pokryte zdobieniami.

Okazy ze stopu miedzi są młodsze, być może z wyjątkiem cmentarzyska w Poznaniu-Sołaczu, którego początki przypuszczalnie sięgają końca X wieku (Kara 2017). Przykładowo, pochówek z Poznania-Śródki z dwoma egzemplarzami, z których jeden wyróżnia się pionowo wyciskanymi żeberkami (pseudofiligran?), datowany jest na 2. połowę XI do XI/XII wieku (Kóčka-Krenz, Pawlak i Sikorski 1995, s. 291). Z kolei niezdobione kaptorgi z Napola (grób nr 14) odkryto na nekropolii użytkowanej od schyłku XI do przełomu XII/XIII wieku (Bojarski 2014, s. 175).

$\mathrm{Z}$ końcem $\mathrm{X}$ wieku na ziemiach polskich zaczęły się też pojawiać kaptorgi trapezowate, których używano do XII wieku (Kóčka-Krenz 1993, s. 87). Z kolei według A. Sztyber dolną cezurę chronologiczną ich występowania stawiać należy w połowie XI wieku (skarby), natomiast górną - w początkach XIII wieku (Sztyber 2010, s. 46), o ile słuszne jest zaliczenie do tejże grupy egzemplarza poddębickiego, co jednak budzi poważne wątpliwości ${ }^{28}$. Na wcześniejszą chronologię wskazują znaleziska grobowe. Na podstawie dostępnych danych można stwierdzić, iż z kaptorgami tej odmiany zmarli chowani mogli być już w pierwszych latach $\mathrm{XI}$ wieku, a nawet u schyłku X stulecia.

${ }^{28}$ Zob. przyp. 14. 


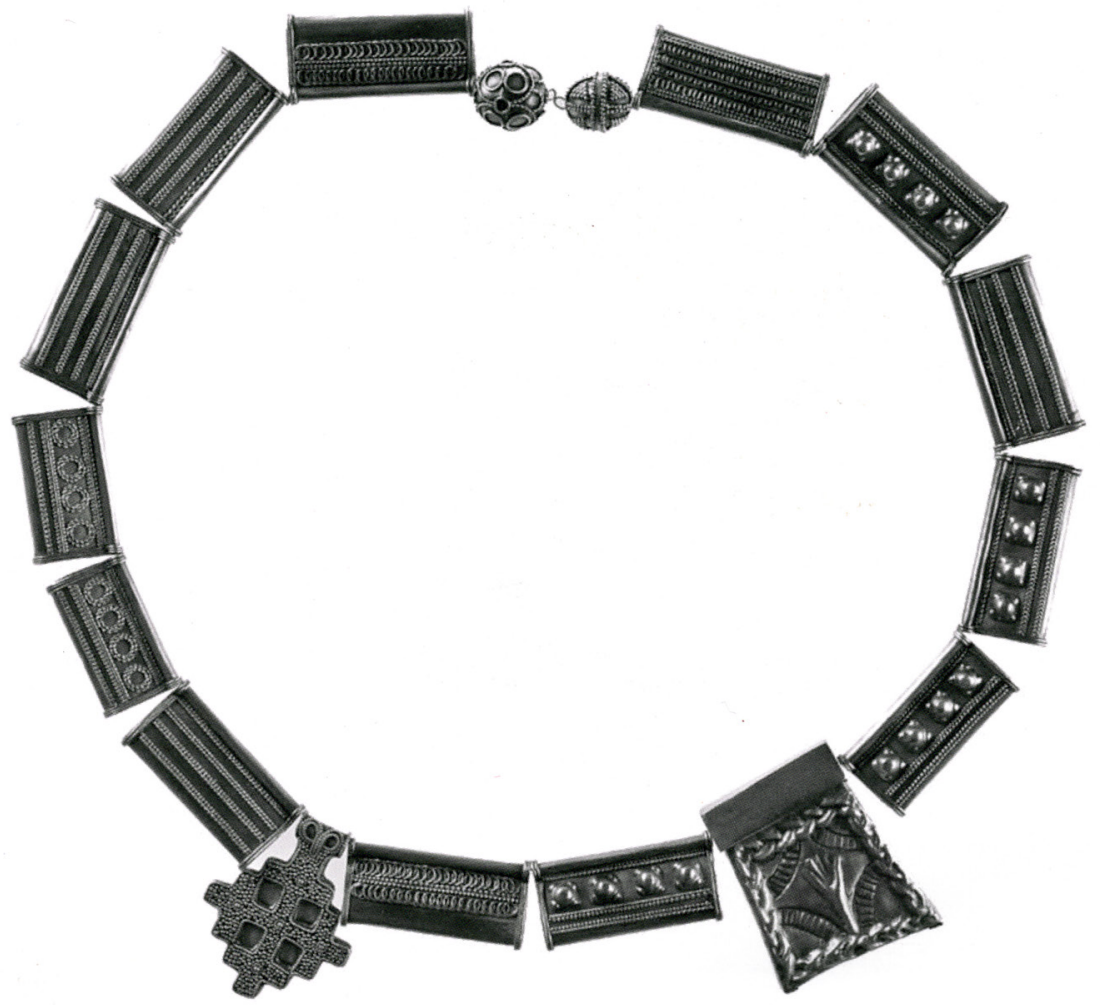

Ryc. 14. Rekonstrukcja kolii z grobu nr 62/08 w Dziekanowicach (wg Wrzesiński [red.] 2019, tabl. 167:2). Oprac. T. Kurasiński

Data radiowęglowa pozyskana dla szczątków ludzkich z pochówka E864/II $(1070 \pm 30$ BP) z Bodzi wskazuje na przedział kalendarzowy 895-1021 AD (Goslar 2016, s. 454; Sikora 2015, s. 158). Odkryty przy szkielecie zbiór monet również nie wykracza poza pierwsze dziesięciolecia XI wieku (Suchodolski 2016, s. 290-291; 2018, s. 24-25). Niemal tak samo datowany jest wymieniony wcześniej grób dziekanowicki (nr 62/08), zawierający oprócz kaptorg prostokątnych również jeden okaz trapezowaty. Monety znalezione w grobie nr E72 w Bodzi przypuszczalnie zdeponowano nie później niż na przełomie X/XI wieku (Suchodolski 2016, s. 288). Kaptorgi trapezowate $\mathrm{z}$ pozostałych grobów wiązane są głównie z XI stuleciem (zob. Urbańska 1959, s. 185; Gąssowski 1969, s. 404; Marciniak 1960, s. 171).

Biorąc pod uwagę prostą formę i uproszczone zdobnictwo oraz surowiec, wydaje się, że egzemplarz z Radomia powstał w miejscowym środowisku, przypuszczalnie jako naśladownictwo zawieszek kunsztowniej wykonanych. Na podstawie analogii można ją datować jedynie w szerokim zakresie między XI (ze wskazaniem 
na połowę tego stulecia) a końcem XII wieku. W takich też granicach czasowych mieszczą się pozostałe elementy wyposażenia grobowego (zob. Kurasiński i Skóra 2016).

\section{KWESTIE FUNKCJONALNE I ZNACZENIOWE}

W najbardziej rudymentarnym sensie funkcja omawianych zawieszek semantycznie zakodowana jest już w samym terminie „kaptorga”. Etymologicznie wywodzi się on $\mathrm{z}$ języka tureckiego (qapturya), wykazując przy tym korzenie mongolskie. Oznacza skórzany mieszek lub sakiewkę na drobne przedmioty, noszoną przy pasie, choć przypuszczalnie stosowano go również w odniesieniu do metalowych elementów pasa (na ten temat szczegółowo w Dobrodomov 2008; zob. także Gabriel 1988, s. 181; Zhilina 2002, s. 173-175). Dodajmy, iż o prostokątnych mieszkach określonych jako cabtargac (wyraz mający dość dokładny odpowiednik słowa mongolskiego) wspomina Wilhelm z Rubruk w swym opisie podróży do Mongołów, podjętej w latach 50. XIII wieku. Wkładano do nich m.in. kawałki mięsa lub kości (Wilhelm z Rubruk 2007, III, 2, s. 82, zob. też przyp. 38).

Zwyczaj noszenia tego rodzaju puzderek przyjął się w XIV wieku na Rusi Moskiewskiej (zob. przykład w Stepanova 2020, s. 287, ryc. 1:12), skąd - jak uważa W. Duczko - dotarł do Polski. Ostatecznie nazwa przyjęła się w terminologii archeologicznej na określenie metalowych pojemniczków-kapsułek (Duczko 2016, s. 141).

Z powyższych względów kaptorgi najogólniej traktuje się jako schowki na określoną zawartość - amulety, relikwie bądź wonności, jednak konkretyzacja przeznaczenia okazów odkrywanych na terenach słowiańskich, w tym na ziemiach polskich i przybliżenie ich roli odgrywanej w społecznościach wczesnośredniowiecznych okazuje się zagadnieniem wysoce złożonym.

Część badaczek i badaczy skłania się ku relikwiarzowej funkcji omawianych zawieszek, szczególnie trapezowatych (Hołowińska 1959, s. 86-87; Kowalczyk 1968, s. 105; Kihl-Byczko 1970; Hensel 1987, s. 595). Taka koncepcja bierze się z ich formalnego podobieństwa do przenośnych relikwiarzy sakwowych z VII-XI wieku, które stawiane były na ołtarzu lub wieszane nad nim, a także noszone przez duchownych na piersiach $w$ czasie procesji przebłagalnych (zob. ryc. 16) (por. Szczepkowska-Naliwajek 1996, s. 74-81, ryc. 12-14). Według K. Szczepkowskiej-Naliwajek kaptorgi w większości pochodzą jednak ze skarbów o ,jednoznacznie świeckim charakterze", a znajdująca się w nich zawartość nie przypomina relikwii (Szczepkowska-Naliwajek 2000, s. 27).

Przeprowadzone analizy wykazały bowiem obecność szczątków organicznych, najczęściej pochodzenia roślinnego. Stwierdzono występowanie ziarniaków prosa zwyczajnego lub włośnicy beru (Kóčka-Krenz, Pawlak i Sikorski 1995, s. 287; Pawlak 1998, s. 259; Rennwanz 2019), włókien konopnych (Opravil i Lutovský 


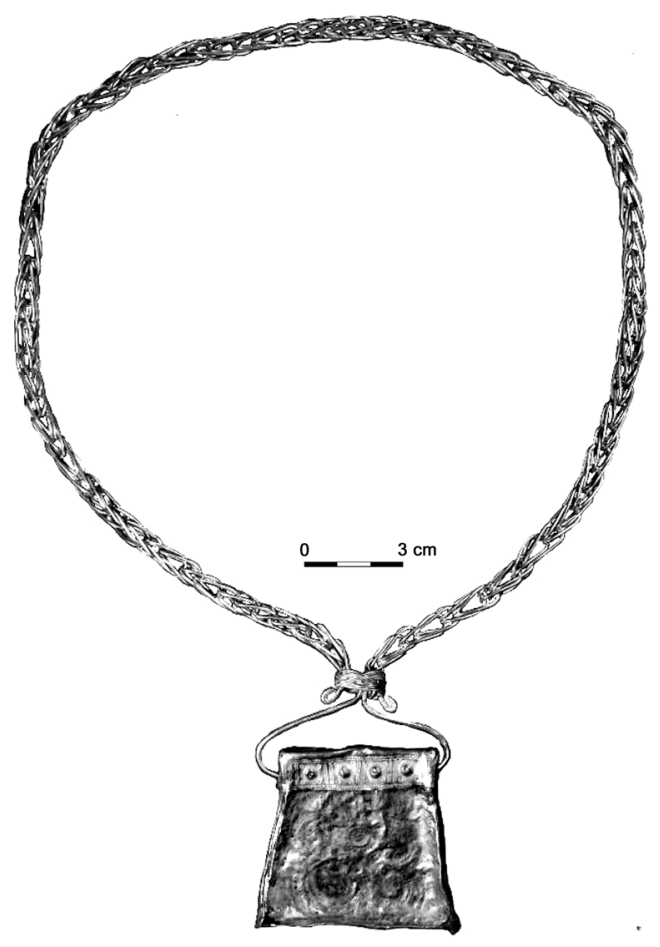

Ryc. 15. Kaptorga ze skarbu w Olbrachtówku (wg Czonstke i Koperkiewicz 2013, tabl. I:6).

Oprac. T. Kurasiński

1993) i lnianych (Koszałka 2016, s. 95, 97) oraz pozostałości drewna modrzewiowego i świerkowego (Wrzesiński 2015, s. 46, ryc. 32-33; Michniewicz 2015, s. 127) lub dębowego (Kurasiński i Skóra 2012, s. 97, 174; Michniewicz 2012, 336). W kilku kapsułkach natrafiono na fragmenty tkanin (Šolle 1959, s. 454; 1966, s. 267; Marciniak 1960, s. 170; Krumphanzlová 1963, s. 101; 1971, s. 431; Profantová, Špaček i Novotná 2011, s. 541), a ponadto odnotowane zostały kawałki kości, włosy lub sierść, resztki wełny i skóry, wosk pszczeli, grudki gliny, zwęglone drewno i fragmenty paciorków szklanych (Štefan 2004, s. 44; Profantová i Šilhová 2010, s. 296; Profantová i Daněček 2017, s. 93, 97; Kołyszko 2019, s. 48; Miazga, Rodak, Lucejko i Ribechini 2020, s. 548-551). W niektórych przypadkach zawartość schowka złożona była z kilku wymienionych komponentów. Niekiedy można było co najwyżej stwierdzić pozostałości nieokreślonej substancji pochodzenia organicznego (Lepówna 1981, s. 174, 187; Nadolski, Poklewski i Abramowicz 1959, s. 81). Niestety, zły stan zachowania kaptorg z Radomia udaremnił podjęcie próby przeprowadzenia podobnych badań, stąd nie wiadomo, co 
mogło się w nich pierwotnie znajdować. Wprawdzie w jamie grobowej natrafiono na pestki winogron (Kurasiński i Skóra 2013), ale brak informacji na temat ich zalegania pozwala sformułować jedynie hipotetyczną sugestię o związku obu tych znalezisk (Kurasiński i Skóra 2016, s. 82).

W badaniach nad poruszoną problematyką podkreśla się apotropaiczną i magiczną moc tego rodzaju szczątków (Wawrzeniuk 2016, s. 122), stąd często zawartość kaptorg uznaje się za przejaw wierzeń pogańskich, pozostających w opozycji do wiary chrześcijańskiej (z odniesieniem do literatury Kajkowski 2016, s. 446; 2019, s. 248-249). Wkładane do wnętrza specjalne komponenty służyć miały w tzw. białej magii jako środek pomocny w rozwiązywaniu wszelkiego rodzaju losowych przeciwności (Štefan 2004, s. 45).

Wedle innej interpretacji, kaptorgi mogły służyć jako schowki do przechowywania substancji aromatycznych, przede wszystkim o pochodzeniu roślinnym (Turek 1962, s. 140; Duczko 1985, s. 63; Gabriel 1988, s. 184; Brather 2008, s. 349). Wyrażana jest również możliwość wkładania do nich nasączonych wonnościami tkanin (Profantová i Šilhová 2010, s. 297). Analiza specjalistyczna pozostałości tekstylnych znajdujących się w kaptordze z Dąbrowy Górniczej-Strzemieszyc Wielkich nie potwierdziła obecności tego rodzaju substancji (Marciniak 1960, s. 171). Wprawdzie nie można wykluczyć, iż rozpatrywane zawieszki zawierały jakieś pachnidła ${ }^{29}$, to jednak na poparcie tej tezy nie dysponujemy żadnymi przekonywającymi dowodami (Sztyber 2010, s. 54).

W opinii niektórych badaczy bezpośrednie morfologiczne podobieństwo do wspomnianych relikwiarzy wykazują co najwyżej okazy trapezowate i tylko one mogłyby ewentualnie pełnić funkcję pojemników na relikwie (Sztyber 2010, s. 53). Natomiast kaptorgi odmiany prostokątnej są zbudowane inaczej, a ponadto ich zdobnictwo odbiega od symboliki chrześcijańskiej (o czym dalej). Pojawiła się myśl, że w przypadku takich okazów jedynie rzemieślnik miał sposobność umieszczenia czegokolwiek wewnątrz, gdyż były one zespalane (lutowane) na stałe. Mogły to być składniki o znaczeniu magicznym, jakkolwiek zanegowano, aby chodziło o relikwie (Duczko 1972, s. 78). Późniejsze obserwacje przyczyniły się jednak do zrewidowania powyższej koncepcji. Zwrócono uwagę, że prostokątna zawieszka z Birki ma zamknięcie tylko z jednej strony, podczas gdy druga pozostała otwarta, bez śladów blaszanej pokrywy. Okazy prostokątne nie były zatem konstrukcjami całkowicie zamkniętymi i dawały możliwość także późniejszego ingerowania w ich zawartość (Duczko 1985, s. 62-63). W odniesieniu do okazów dziekanowickich stwierdzono, że jeden bok był zamykany rodzajem łezkowatej w kształcie pokrywy, o krawędziach zawiniętych do wewnątrz i dopasowanych do zarysu otworu. Przeciwległą zaś stronę zalutowywano na stałe (Strobin 2015, s. 145, 147; Wrzesiński 2015, s. 34). Tak więc nie tylko konstrukcja okazów

\footnotetext{
${ }^{29}$ Również one mogły mieć apotropaiczne znaczenie. Jak twierdzi I. Štefan (2004, s. 44) nieadekwatne dla wczesnego średniowiecza jest rozłączne traktowanie funkcji kosmetycznej i magicznej.
} 

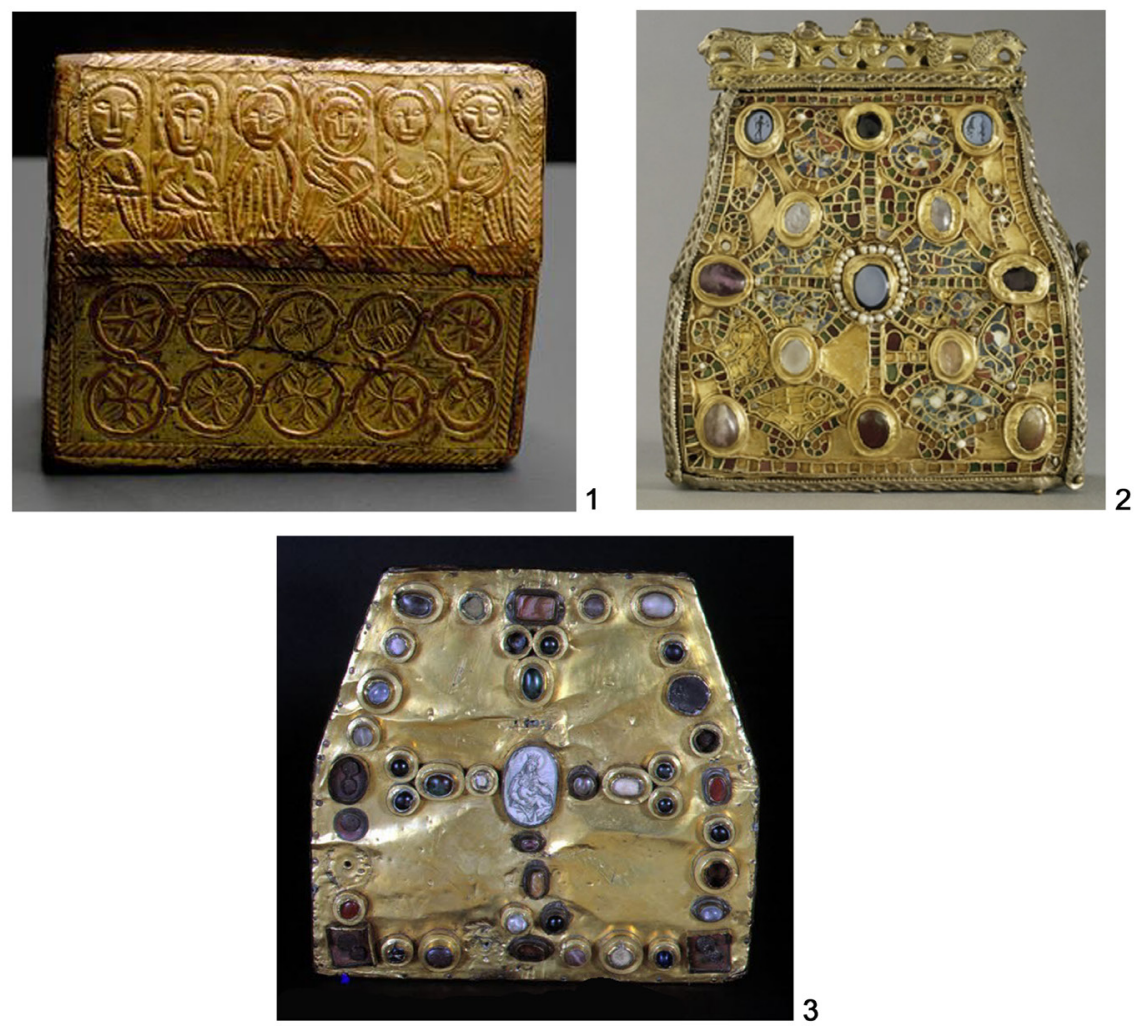

Ryc. 16. Relikwiarze sakwowe. 1 - kościół opacki w Saint-Benoit-sur-Loire (Centre-Val de Loire, Francja), 2. połowa VII w. (wg https://www.akg-images.com/Explore/Tag/MUMMA, dostęp 5.12.2020); 2 - kościół opacki św. Dionizego w Enger (Westfalia, Niemcy), przechowywany w Kunstgewerbemuseum w Berlinie, 3. ćwierć VIII w. (wg https://smb.museum-digital.de/index.php?t=objekt\&oges=82892, dostęp 5.12.2020); 3 - kościół parafialny św. Korneliusza i Cypriana w Metelen (Westfalia, Niemcy), X w. (wg https://www.lwl.org/marsLWL/ de/instance/picture/Mittelalterliche-Kunst-in-Westfalen---Publikationsprojekt-LWL-1998-ff. xhtml?oid=36213, dostęp 5.12.2020). Oprac. T. Kurasiński

trapezowatych pozwalała na rozmontowanie całości w celu uzupełnienia, częściowego zastąpienia bądź całkowitej wymiany składu zawartości. Niestety, stan zachowania kapsułek z Radomia pozbawia nas możliwości wypowiadania się na ten temat.

Wolno natomiast za K. Kajkowskim (2019, s. 249) zadać pytanie, czy kaptorgi wykonywano na spersonalizowane zamówienie i czy użytkownikowi znana była ich zawartość. Badacz ten, kierując się niewystarczającym zasobem danych, pozostawia je bez odpowiedzi, z czym wypada się zgodzić, aczkolwiek można zaryzykować odpowiedź twierdzącą, tym bardziej że chodziłoby - do czego wrócimy - 
o osoby z kręgu warstw uprzywilejowanych. Przemawia za tym także mocno zróżnicowany skład umieszczanych wewnątrz komponentów, same zaś kaptorgi, biorąc pod uwagę ich formę, zdobnictwo, wymiary czy surowiec, również nie stanowią homogenicznego i zestandaryzowanego zbioru wyrobów (nawet w obrębie jednej odmiany zob. Czonstke i Koperkiewicz 2013, s. 226) 30. Są wśród nich egzemplarze wyróżniające się pod względem kunsztu wykonania i zastosowanego repertuaru motywów symbolicznych, jak również mniej wyrafinowane, o uproszczonym zdobnictwie, a niekiedy także całkiem go pozbawione.

W ostatnim czasie czynione są próby nadania omawianym przedmiotom „chrześcijańskiej" wymowy, zarówno jeśli chodzi o to, co się w nich mieściło, jak i o dekoracyjny wystrój. Stanowi to niejako nawiązanie do starszych prac, gdyż taka propozycja wyjaśnienia pojawiła się w odniesieniu do cynowej kaptorgi trapezowatej znalezionej w domostwie nr 125 w Gdańsku. Dwustronnie przedstawiony na zawieszce ptak został zinterpretowany jako gołąb (gołębica) - chrześcijański symbol Ducha Świętego, a sam przedmiot bezpośrednio powiązany z akcją misyjną św. Wojciecha (Hołowińska 1959, s. 86-87; Lepówna 1981, s. 174, 187) ${ }^{31}$. Idąc tym tropem, zmierzono się z problemem odczytania wizerunków i przedstawień widniejących na innych kaptorgach trapezowatych z ziem polskich. Wśród wyróżnionych motywów zoomorficznych (gryfy, smoki, lwy, ptaki ${ }^{32}$ ), roślinnych, antropomorficznych i geometrycznych, będących centralnym elementem układu kompozycyjnego, niemal wszystkie zostały uznane za chrześcijańskie (Zawol 2018; zob. także Kóčka -Krenz 2014, s. 34; Zawol 2015; por. Krumphanzlová 1971, s. 431, 434-435). Wiążące się z nimi treści symboliczne i mitologiczne, głęboko zakorzenione w przeszłości, poddawano egzegezie zgodnej z aktualnie obowiązującymi kanonami religijnymi i włączano do zasobów ikonograficznych i środków artystycznego wyrazu sztuki romańskiej. Stosowanie form roślinnych i zwierzęcych w ówczesnej stylistyce ornamentacyjnej miało na celu wywołanie opartej na języku pamięci rzeczywistości aksjologicznej, służącej przywoływaniu i aktywizowaniu określonych treści teologicznych i ewangelicznych, w tym odnoszących się do moralistyki (Jakóbczyk-Gola 2013, s. 88, 105). Ukazanie ich na kaptorgach miałoby tym samym za zadanie wyrażać prawdy wiary, stanowić ostrzeżenie przed czyhającym złem i przypominać o nagrodzie zbawienia (Zawol 2015, s. 119; 2018, s. 484).

\footnotetext{
${ }^{30} \mathrm{Na}$ podstawie wyników specjalistycznych analiz kilku kaptorg z terenu Czech wykazano, że istniał tam wyspecjalizowany warsztat produkcyjny tego rodzaju wyrobów, ulokowany na grodzie praskim lub w jego pobliżu. Mimo podobieństw między poszczególnymi okazami nie była to wszakże wytwórczość masowa i zestandaryzowana. Lokalni złotnicy czynili wysiłki w celu nadania indywidualnego charakteru każdemu egzemplarzowi (Frolíková, Ottenwelter i Barčáková 2020, s. 275, 286; zob. także Sztyber 2010, s. 56; Profantová i Daněček 2017, s. 111; Matla 2020, s. 187).

${ }_{31}$ Teza ta spotkała się z krytyką (Kajkowski 2016, s. 446).

${ }^{32}$ Nie wszystkie wizerunki zwierzęce udało się zidentyfikować, jak na przykład ten na okazie z Dąbrowy Górniczej-Strzemieszyc Wielkich (zob. ryc. 8:3) (Zawol 2018, s. 473), choć można spotkać się z koncepcją, iż jest to przedstawienie gryfa (Tokaj 2009).
} 

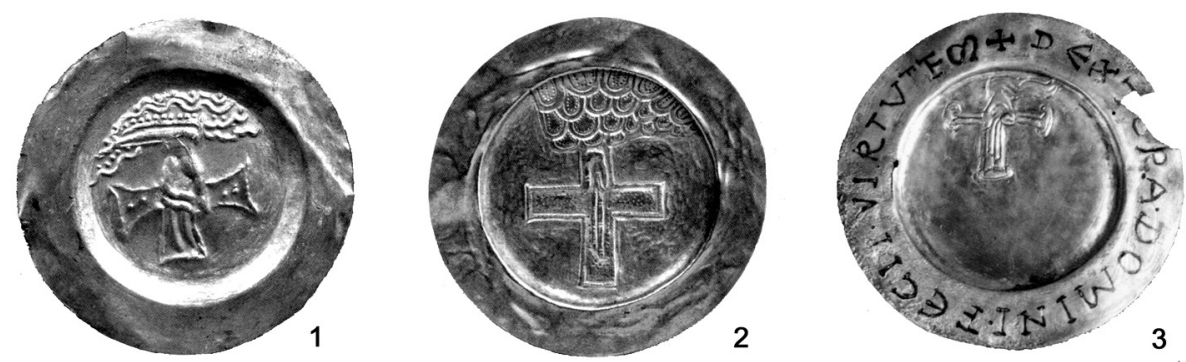

Ryc. 17. Pateny z wyobrażeniem Ręka Pana/Boga pochodzące z grobów duchownych. 1 - Kraków-Wawel, katedra św. Wacława i Stanisława (krypta św. Leonarda), przed 1118 r.; 2 - Kraków-Tyniec, kościół klasztorny benedyktynów św. Piotra i Pawła, połowa XI w. (wg Firlet i Zaitz [red.] 2006, ryc. na s. 374); 3 - Tum pod Łęczycą, kolegiata Wniebowzięcia Panny Maryi i św. Aleksego, 2. połowa XI w. (wg Augustyniak [red.] 2000, ryc. 62). Oprac. T. Kurasiński

We wczesnym średniowieczu świat zwierzęcy w szerokim zakresie zawładnął ówczesną wyobraźnią ludzką, znajdując wyraz m.in. w obfitości wytworów artystycznych i przedmiotów niższej rangi. Jak już wzmiankowano, zoomorfizmy na ogół odwoływały się do pokładów znaczeniowych o charakterze religijno-mitycznym $^{33}$. Wydaje się, iż zasadniczy nurt tych przedstawień odwoływał się do dychotomicznej koncepcji świata, będącego areną zmagań istoty boskiej (Boga) bądź jej przedstawiciela (świętego, herosa) z reprezentantami zła, wśród których sytuowały się zwierzęta oraz różnego pokroju monstra i demony ${ }^{34}$. Znamienne dla tego archetypicznego tematu jest uosabianie fauny ze złem (Solik 2003, s. 71-73). Jednocześnie wyobrażenia związane ze zwierzętami mogły w określonych okolicznościach przyjmować także pozytywne skojarzenia, co wynika z ambiwalentnej i poliwalentnej natury wszelkich symboli, czy w ogóle sacrum (pociągającego, a zarazem budzącego trwogę). Te dodatnio waloryzowane motywy zoomorficzne (np. lew, kogut, jednorożec, jeleń czy orzeł) na ogół koncentrowały się wokół chrystologicznych, maryjnych i ewangelicznych wątków tematycznych (Solik 2003, s. 76-78; Davy 2011, s. 247). W perspektywie powyższych uwag wolno przypuszczać, że

${ }^{33} \mathrm{Na}$ zasygnalizowanie zasługuje tu śmiała koncepcja utożsamiająca podwojone zwierzęce stwory ukazywane na licznych zabytkach pochodzących z terenów zachodniosłowiańskich, w tym na kaptorgach (jako przykład podawana jest m.in. patryca z Brześcia Kujawskiego) z mitycznym Żmijem. W słowiańskich wierzeniach ludowych istota ta często jednoczyła w sobie cechy gadzie i ptasie (zob. Gardeła, Kajkowski i Ratajczyk 2019, s. 107-110).

${ }^{34} \mathrm{~W}$ rolę konwencjonalnego i oddziaływającego szczególnie mocno na wyobraźnię adwersarza często wcielał się smok, nie tylko zresztą w wiekach średnich (np. Bąbel 2004; Gierszewska 2012; Mianecki 2012; Sikorski M. 2015; Honneger 2019). Dołączał do niego gryf i lew, które uwidoczniono m.in. na piastowskich monetach i pieczęciach w scenach walki władców $\mathrm{z}$ tymi bestiami (np. Panfil 1999-2000; Kuś 2007). 
wizerunki animalne znajdujące się na kaptorgach same w sobie mogły pełnić funkcję magiczno-ochronną (zob. Vavák 2015, s. 246; por. Skubiszewski 2001, s. 88), abstrahując od tego, czy czerpały swą moc z dawnych przedchrześcijańskich pokładów znaczeniowych, czy sankcjonowała je nowa wiara. Wiele bowiem wskazuje, iż nadanie symbolom zawartym na rozpatrywanych zawieszkach, często o odległej genezie, chrześcijańskich treści może świadczyć, że „symbolika pogańskiego świata nie stała w jaskrawej, zauważalnej sprzeczności z nową ideologią i możemy mieć do czynienia $\mathrm{z}$ łagodnym przejściem jednego zespołu symbolicznego $\mathrm{w}$ drugi” (Kóčka-Krenz 1993, s. 165).

Zdaniem S. Brathera, kaptorgi nie powinny być traktowane jako świadectwo przyjęcia wiary chrześcijańskiej, gdyż pojawiają się już w czasach pogańskich (jak np. u Słowian nadłabskich) i mają bezpośrednie wzorce w innych religiach, przykładowo w islamie. Tym niemniej dostrzegalna jest wyraźna zbieżność przestrzenna i czasowa ich występowania z chrystianizacją (Brather 2008, s. 349).

$\mathrm{Na}$ uwage zasługuje przy tym niemal zupełny brak jednoznacznych i bezpośrednich odniesień do symboliki chrześcijańskiej, co w myśl niektórych zapatrywań pozwala zanegować związek kaptorg z nowo przyjmowaną wiarą (Štefan 2004, s. 43). Wbrew temu przekonaniu dostrzegany jest znak krzyża, którego obecność - pod postacią rozetki (zob. ryc. 8:2) - upatrywana jest na jednej z zawieszek znalezionych w Bodzi z sylwetką orła (Duczko 2016, s. 143). Z kolei na jednym z okazów trapezowatych ze skarbu odkrytego w Chełmie Drezdeneckim na tylnej jego ściance ukazano motyw, będący w ocenie L. Gąssowskiej (1979, s. 136) stylizowaną formą krzyża maltańskiego, rozpowszechnioną w sztuce bizantyjskiej, aczkolwiek „może to być również nawiązanie do chrześcijańskiej symboliki kwiatów lub Drzewa Życia" (Zawol 2018, s. 477). Innym, choć także tylko hipotetycznym przykładem, jest okaz z cmentarzyska w Kwiatkowie (ryc. 10:1). Znajdujący się na niej motyw geometryczny przypomina krzyż św. Andrzeja (Zawol 2018, s. 483). Z kształtem krzyża bardziej przekonująco kojarzy się zgeometryzowany ornament widoczny na kaptordze z grobu nr 28/01 w Dziekanowicach (ryc. 9:1) (Wrzesiński 2019, s. 70, 75).

$\mathrm{Z}$ jedynym niebudzącym wątpliwości przedstawieniem o chrześcijańskiej wymowie mamy do czynienia na trapezowatym egzemplarzu także pochodzącym z cmentarzyska dziekanowickiego (grób nr 106/05). Motywem centralnym jest tu wyłaniająca się z chmur Ręka Pana/Boga (Dextera Domini - Dextera Dei) (ryc. 9:2). We wczesnym średniowieczu był to przekaz o ogromnym ładunku symbolicznym, znany m.in. z romańskich naczyń liturgicznych (Wrzesiński 2015, s. 41, ryc. 28; Zawol 2018, s. 482) (zob. ryc. 17). Na kaptordze z Dziekanowic nieboskłon z wychodzącą z niego dłonią został ukazany u jej podstawy, tworząc niejako układ odwrotny. Ów „niekanoniczny” sposób przedstawienia mógł wynikać z braku zrozumienia właściwego sensu tego chrześcijańskiego motywu. Jeśli jednak przyjąc punkt widzenia osoby noszącej zawieszkę i spoglądającej na nią z góry, to całość daje się już poprawnie „odczytać”. Przedmiot widziany w takiej 
perspektywie ujawnia swą bezpośrednią relację z właścicielem i/lub dysponentem, sugerując tym samym, że poprawne znaczenie zawartych na nim treści symbolicznych nie było mu obce.

Chrześcijańska wymowa kaptorg trapezowatych uznawanych za „relikwiarze osobiste" w założeniu powinna znaleźć potwierdzenie w ich zawartości. Stąd uważa się, że do środka wkładano określone relikwie kontaktowe w typie brandeum, które miały styczność z relikwiami właściwymi, najczęściej kosztowne tkaniny 35 oraz eulogiae, będące pamiątkami przywożonymi z miejsc kultu świętych przy okazji pielgrzymek, takimi jak kamyki, cząstki gałązek czy kwiatów. Odpowiadają one wielu wymienionym wcześniej składnikom zidentyfikowanym wewnątrz kaptorg (Zawol 2015, s. 122; 2018, s. 484; por. Weidemann 1977).

Treści chrześcijańskie przypisywane są także pozostałościom wosku. Stężałe resztki tej substancji stwierdzone w kaptordze z Dziekanowic (grób nr 28/01) (zob. ryc. 9:1) powiązano ze zwyczajem noszenia przy sobie agnuska - wosku pochodzącego ze świecy (paschału), uformowanego w medalion $\mathrm{z}$ odciśniętym wizerunkiem Baranka Paschalnego, niekiedy wkładanego do metalowej kapsuły lub specjalnie oprawianego. Agnusek miał skutecznie chronić przed chorobami, piorunami, demonami i wszelkimi innymi nieszczęściami (Kołyszko 2019, s. 349-353; por. Nowiński 2011$)^{36}$. Także w przypadku zbóż możliwe są odniesienia zarówno do obyczajowości tradycyjnej, jak i wiary chrześcijańskiej, jeśli przyjąć, że ziarno jest symbolem zmartwychwstania i odrodzenia (Wrzesiński 2019, s 75). Z kolei fragmenty drewna nasuwają myśl o partykułach Drzewa Krzyża Świętego (Kara 2016, s. 369-370), choć akurat w tym przypadku byłoby to dość problematyczne. Ta szczególnie cenna relikwia Męki Pańskiej na ziemiach polskich upowszechniła

${ }^{35}$ Przywoływane są tu także płótna grobowe Chrystusa, które zgodnie z utrwalonym w średniowieczu przekonaniem zostały utkane z lnu (Kara 2016, s. 369-370). W tym kontekście warto zwrócić uwagę na znajdujące się wewnątrz kaptorgi z cmentarzyska w Dąbrowie Górniczej-Strzemieszycach Wielkich „potrójne zawiniątko (każde przewiązane sznureczkiem)" bielonej tkaniny lnianej (Marciniak 1960, s. 170). Pozostając w tym kręgu znaczeń, trzeba też mieć na względzie, iż w średniowieczu relikwie były zawijane w tekstylia, najczęściej kosztowne (jedwab), a także w pergamin. Celem takiego zabiegu było przede wszystkim uchronienie świętości przed skalaniem, do czego przyczyniłby się bezpośredni dotyk. Usunięcie relikwii z pola widzenia służyło też potwierdzeniu i wzmocnieniu ich szczególnego statusu jako obiektów symbolizujących niewidzialną obecność Boga i jego moc. Chroniło ponadto przed kradzieżą. Całun, w który - jak mniemano - owinięto ciało świętego, lub szata, w której został pochowany, często stawały się relikwią samą w sobie. Tym samym dochodziło do zacierania granicy między relikwiami-tkaninami a materią służącą jedynie za „opakowanie” świętych szczątków (szerzej na ten temat zob. Bagnoli 2014; zob. także Schorta 2005). W tym kontekście interesująco przedstawia się obecność w kaptordze z Zeleneč lnianej tkaniny - zapewne woreczka, zawierającego materię organiczną - fragmenty zwęglonego drewna przypominającego węgiel drzewny (Profantová, Špaček i Novotná 2011, s. 541, 550). Obecność tekstyliów mogła zatem służyć raczej jako zabezpieczenie niezachowanej materii organicznej aniżeli stanowić samoistną zawartość kaptorgi (Ungerman 2007, s. 230).

${ }^{36}$ Występowanie wosku w grobach wczesnośredniowiecznych z Europy Środkowo-Wschodniej (zwłaszcza komorowych) w postaci świec lub placków interpretuje się jako apotropaiony, dające jednocześnie świadectwo stopniowo postępującej konwersji elit na chrześcijaństwo (Janowski 2014). 
się bowiem dopiero w XIII-XV wieku. Z okresu wcześniejszego niewiele jest informacji na temat takich pamiątek. Najstarszym (1. połowa XII wieku), a jednocześnie najlepiej udokumentowanym źródłowo potwierdzeniem ich obecności w państwie wczesnopiastowskim jest przekaz o ofiarowaniu tej partykuły (razem z innymi relikwiami) przez Salomę, wdowę po Bolesławie Krzywoustym, benedyktyńskiemu opactwu w Zwiefalten. Najprawdopodobniej w XII stuleciu do Polski sprowadzono cząstki Krzyża umieszczone w staurotece z Łęczycy, datowanej na 3. ćwierć XI wieku (Starnawska 2008, s. 106-112; 2017, s. 48). Kult tej relikwii został poświadczony także archeologicznie. Chodzi o staurotekę krzyżową znalezioną na Ostrowie Lednickim w warstwie wyznaczającej zniszczenie kościoła II $\mathrm{w}$ 1. połowie XI wieku. Zabytkowi przypisywane jest pochodzenie bizantyjskie (Górecki 2009; 2013, s. 90-98).

Przypatrując się zawartości kaptorg, należy liczyć się także z ich pragmatycznym przeznaczeniem, na co wskazują obserwacje względem czeskich okazów. Stwierdzona obecność w nich wosku wynikać mogła z potrzeby wzmocnienia wnętrza przedmiotu (Profantová i Šilhová 2010, s. 296, 297). Wosk (i łój) zmieszany $\mathrm{z}$ innym materiałem organicznym lub mineralnym dobrze sprawdzał się $\mathrm{w}$ roli wypełniacza pozwalającego uniknąc mechanicznej deformacji ścianek podczas wykonywania dekoracji, jak to stwierdzono w przypadku kaptorgi z cmentarzyska Triangle w Pradze-Střešovicích (Frolíková, Ottenwelter i Barčáková 2020, s. 265, 275). Cienka blacha niektórych egzemplarzy wymagała też niekiedy konstrukcyjnego wsparcia w postaci skóry lub drewna (Profantová i Šilhová 2010, s. 287; Profantová, Špaček i Novotná 2011, s. 546, 550).

Wracając do zdobnictwa, można stwierdzić, że wśród kaptorg prostokątnych również spotykane są okazy o bogatym wystroju artystycznym, przy czym nie mają one tak rozbudowanego programu ikonograficznego jak trapezowate. Dominują na nich wątki geometryczne, a jedyna cecha wyróżniająca niektóre egzemplarze to rzędy stylizowanych główek końskich pod rurkowatym zawieszeniem. Tylko jedna kaptorga z takim zdobieniem została odnotowana na cmentarzysku. Znaleziono ją w grobie nr 32/06 w Pniu (ryc. 7:15) (Drozd, Janowski i Poliński 2009, s. 354; Błaszczyk 2020a, s. 105-106, ryc. 26:a, 27).

Jako istota bliska bogom, koń lokuje się wysoko w mitologicznych przekazach rozmaitych kultur, ma również swoje miejsce w symbolice chrześcijańskiej, m.in. alegorycznie ukazuje szybkość zmierzania ludzkiego życia ku celom ostatecznym (Lurker 1989, s. 90-92; Forstner 1990, s. 272-275). Wydaje się, iż pojawienie się tego zwierzęcia na kaptorgach w pierwszym rzędzie mogło odzwierciedlać znaczenie konia w słowiańskich wierzeniach i obyczajowości, decydujące o wysokiej jego pozycji w przestrzeni magiczno-religijnej tamtejszego kręgu kulturowego (zob. np. Rajewski 1974; Herrmann i Lange 1982; Nesen 2003; Łukaszyk 2012; Gapski 2014). Materialnie manifestowało się to m.in. w postaci licznie odkrywanych figurek koników, których wielowymiarowy związek ze sferą sakralną jest wysoce prawdopodobny (Łukaszyk 2012, s. 109-132; Kajkowski i Szczepanik 2012, s. 216-233; 
Kajkowski 2019, s. 185-190; Szczepanik 2020, s. 178-204). W rezultacie wyobrażenie konia, wykazującego silne konotacje obrzędowe i symboliczne, znalazło zastosowanie także w plastycznym wystroju omawianych wyrobów. Trudno wszak rozstrzygnąć, czy tylko jako element zdobniczy, będący echem pogańskiej obrzędowości, nieświadomie aplikowanym na kaptorgi (Łukaszyk 2012, s. 138), czy też krył się za tym głębszy zamysł, polegający przykładowo na przypisaniu końskim główkom znaczenia apotropaicznego (Abramowicz 1962, s. 105) 37.

Dylemat tej samej natury pojawia się także wobec kaptorg radomskich. Trudno powiedzieć, w jakim stopniu rozetki należy traktować jako wątek zdobniczy w typie roślinnym, w jakim zaś jest przekazem treściowo odwołującym się choćby do symboliki kwiatu czy Drzewa Życia (zob. Lurker 1989, s. 48-50, 106-107; Forstner 1990, s. 153-156, 184-186).

Wysoce problematyczne jest też ustalenie (nawet przybliżone) źródła inspiracji, mamy bowiem do czynienia $z$ uniwersalnym i szeroko rozpowszechnionym motywem o bardzo odległej metryce ${ }^{38}$. We wczesnym średniowieczu szeroko wykorzystywano go m.in. w sztuce bizantyńskiej (np. Evans i Wixom [red.] 1997, passim). Pojawia się także w rzemiośle artystycznym okresu karolińskiego (Lennartsson 1997-1998, s. 462, 551, ryc. 4:d - Motiv 29). Dodatkową przeszkodą w ocenie jest mocno uproszczony wizerunek ornamentu znajdującego się na kaptorgach.

Tym niemniej dla niniejszych rozważań warto wspomnieć o srebrnych misach odkrytych w anglosaskim pochówku łodziowym w Sutton Hoo. Każdą z nich zdobi centralnie położona rozeta. Naczynia zostały najprawdopodobniej wykonane we wschodnich prowincjach Cesarstwa Bizantyjskiego około roku 600, a następnie w nieznanych okolicznościach dostały się na Wyspy Brytyjskie. M.D.J. Bintley doszedł do wniosku, iż chrześcijańska symbolika rozet (kwiaty na drzewie życia, drzewo-Krzyż) mogła znaleźć odpowiednik w wyspiarskich wierzeniach tradycyjnych (kult drzew). Tego rodzaju punkty zbieżne, pozwalające na włączenie pewnych aspektów dawnej wiary w nową, wykorzystywane były w procesie nawracania anglosaskich pogan (Bintley 2011).

Oprócz zdobnictwa, magiczno-religijne znaczenie kaptorg wzmacniać mógł zastosowany kruszec do ich wyrobu, zwłaszcza srebro, mające odniesienia do symboliki lunarnej w aspekcie żeńskim (Kóčka-Krenz 1993, s. 163). Natomiast stopy miedzi, stanowiące namiastką złota (tu szczególnie wyróżniać się musiał mosiądz) odwoływać się mogły do pierwiastka solarnego, męskiego wyrażającego boskość, światłość i niezniszczalność (por. Kóčka-Krenz 1993, s. 163). Wartość

37 Warto w tym miejscu przypomnieć koncepcję, według której fragment złotej kaptorgi z końską głową, odkryty w podwalinie wału na Ostrowie Lednickim złożono w charakterze ofiary zakładzinowej (Banaszak i Tabaka 2017, s. 1201; 2020, s. 126-127; Kajkowski 2019, s. 249, przyp. 213).

38 Już w IV tysiącleciu p.n.e. rozeta znalazła się w repertuarze ikonograficznym kultur wschodniej części basenu Morza Śródziemnego, występując tam m.in. jako znak solarny (Hart 2016), oraz mezopotamskich, w licznych wyobrażeniach odnoszących się do symboliki bóstw żeńskich (Van Buren 1939; Ornan 2005, s. 152). 
symboliczna kruszców nabierała szczególnej rangi, gdy wykonane z nich przedmioty służyły kultowi religijnemu (Dzieduszycki 1995, s. 37). Zatem już sama kaptorga, niezależnie od swojej zawartości, mogła zyskiwać walor amuletu (Sztyber 2008, s. 285-286; 2010, s. 50-54; Grzegorczyk 2009, s. 8).

Wiele drobnych wyrobów sporządzonych ze szlachetnych kruszców obok funkcji kultowo-magicznej oferowało swą przydatność w manifestowaniu władzy, prestiżu i zamożności, a tym samym wpisywało się w system społecznego komunikowania (Dzieduszycki 1995, s. 60-61; Duczko 2018, s. 539). Z ostentacyjnym i reprezentacyjnym charakterem liczyć się trzeba także w przypadku kaptorg, nawet jeśli wykonano je z mniej cennego tworzywa (zob. Gabriel 1988, s. 181; Bojarski 2014, s. 181). Za uznaniem ich za element wyróżniający osoby o wysokiej pozycji społecznej przemawiają inwentarze pośmiertne, w których składzie owe zawieszki się znalazły ${ }^{39}$. W grobach obserwujemy obfitości ozdób, zwłaszcza kolii, w których skład, oprócz samych kapsułek, wchodziły paciorki wykonane z różnych surowców, w tym z kamieni półszlachetnych. Kolie te same w sobie przedstawiały dużą wartość prestiżową, czego najlepszym przykładem jest zespół srebrnych ozdób odkryty w Dziekanowicach (grób nr 62/08), złożony z 14 kaptorg, w tym jednej trapezowatej, dwóch paciorków i zawieszki krzyżowatej typu Hiddensee, łączący w sobie cechy wytwórstwa słowiańskiego i skandynawskiego (ryc. 14) (Wrzesiński 2015; 2019, s. 73; Kleingärtner 2015). Poza naszyjnikiem pochówek zawierał jedynie monetę (Suchodolski 2015). Ponadto w większości grobów występowały pierścionki, kabłączki skroniowe i zausznice, często wykonane ze srebra. Wyjątkowymi zabytkami są bransolety (srebrna i platerowana srebrem) z Giecza, z których jedna ma zakończenia w kształcie głów węża (Indycka 2009). Inwentarze pośmiertne uzupełniały noże, naczynia (garnki gliniane i wiadra klepkowe), monety, grzebienie i przęślik gliniany ${ }^{40}$. Na podkreślenie zasługuje fakt obfitego wyposażenia nie tylko osób dorosłych, ale też dzieci, w tym z grupy najmłodszych. Jak wspomniano, również kobietę z cmentarza w Radomiu do grobu złożono z licznym zestawem przedmiotów.

39 Osobną (i otwartą) kwestią jest, czy kaptorgi znalezione na cmentarzyskach stanowiły własność prywatną pochowanych osób, które weszły $\mathrm{w}$ ich posiadanie $\mathrm{w}$ jakimś momencie życia, czy też przechodzącą z pokolenia na pokolenie pamiątkę rodzinną, która tylko okazjonalnie, np. z braku spadkobierców i/lub przedwczesnej śmierci aktualnego właściciela/dysponenta, trafiła do grobu. Za drugą z przywołanych koncepcji przemawiać może wspomniany wcześniej prowizoryczny sposób wieszania omawianych przedmiotów na szyi zmarłych lub tylko go imitujący. Przekazywanie materialnych dóbr zbiorowych (jako family heirlooms) wpisywało się $\mathrm{w}$ model transmisji międzypokoleniowej, skutkującej ich rozszerzonym obiegiem w kontekście wczesnośredniowiecznych zwyczajów pogrzebowych. Pokazuje on, że „sepulkralną” kulturę materialną można badać jako składnik różnych relacji między wspólnotą a jednostkami, określających i podtrzymujących tożsamość grupową, a nie tylko jako odzwierciedlenie statycznych identyfikacji, takich jak status społeczny, pozycja prawna, pochodzenie etniczne czy przynależność religijna (na ten temat zob. Kars 2013).

${ }^{40}$ Szczegółowe informacje na temat wszystkich tychże przedmiotów znajdują się w publikacjach wymienionych w zestawieniu pochówków z kaptorgami. 
Najskromniej pod tym względem prezentują się pochówki nr 30 z Cedyni, nr 27/57 z Kałdusa, stan. 1 i nr 6 z Parchanek, w których jedynymi znaleziskami poza kaptorgami ze stopu miedzi (bez innych składników kolii) są - odpowiednio - wiadro klepkowe, nóż i dwa brązowe kabłączki skroniowe.

Efektowne i urozmaicone zestawy przedmiotów, wśród których znajdowały się kaptorgi, stały się cechą pochówków nie tylko z cmentarzysk doby wczesnopiastowskiej, ale też czeskich i morawskich (zob. Štefan 2004; Profantová i Šilhová 2010; Sztyber 2010, s. 54-56; Profantová, Špaček i Novotná 2011; Profantová i Daněček 2017; Frolíková, Ottenwelter i Barčáková 2020).

Groby z omawianymi zawieszkami niejednokrotnie wyróżniają się także pod względem wielkościowym i konstrukcyjnym. Mamy wśród nich duże założenia drewniane określane jako komorowe (Bodzia, Dziekanowice, grób nr 62/08, Kałdus, stan. 4, Pień) bądź mniejsze, w typie trumien czy oszalowań (Lubień, PoznańSołacz $^{41}$, Poznań-Śródka, Sandomierz), a także wzniesione przy użyciu kamienia (Gozdowo). Zapewne był to jeszcze jeden przejaw elitarnego charakteru pochówków zawierających kaptorgi, zwłaszcza w odniesieniu do grobów komorowych (zob. Janowski 2015, s. 73-80). Również w Radomiu grób, do którego trafiły te przedmioty, lokuje się w grupie kilku największych w skali całego cmentarzyska (ryc. 1-2). Nie można wykluczyć, że nawiązuje on do idei chowania zmarłych we wspomnianych grobach komorowych (Kurasiński i Skóra 2016, s. 28-30). Wszystko to prowadzi do wniosku, iż status kobiety pochowanej w Radomiu także pod tym względem jawi się jako ponadprzeciętny.

Zjawiska noszenia tego rodzaju zawieszek i chowania $\mathrm{z}$ nimi zmarłych nie można rozpatrywać w oderwaniu od przemian ustrojowo-religijnych zachodzących na terenie kształtującego się państwa wczesnopiastowskiego. Proces chrystianizacyjny nie zaznaczał się sprawnym i bezkolizyjnym przebiegiem, niewykonalne było bowiem całkowite i natychmiastowe wyrugowanie wszystkich przejawów głęboko zakorzenionych zachowań pogańskich. Wraz z oficjalną konwersją musiało dojść do konfrontacji postaw światopoglądowych, wyrastających $\mathrm{z}$ obydwu skonfrontowanych ze sobą systemów wartości. Jednocześnie następowało wzajemne ich przenikanie i dostosowywanie do nowych warunków, co przekładało się na obraz rzeczywistości nacechowany swoistym synkretyzmem, dającym się uchwycić m.in. w obrzędowości pogrzebowej oraz kulturze materialnej i artystycznej (zob. np. Gąssowski 1993; Jaguś 2000; Urbańczyk 2015; 2020). W tej sytuacji jednoznaczne rozstrzygnięcie, czy dany przedmiot stanowił element „pogański”, czy „chrześcijański” jawi się jako wysoce problematyczne.

Powyższe uwagi dobrze odnoszą się do kaptorg. Nosiły je kobiety, które z racji przynależności do elity społecznej w pierwszej kolejności i w szerokim

${ }^{41}$ W tym przypadku na obecność konstrukcji drewnianej wskazywać może odchylenie żuchwy „typowe dla szkieletów rejestrowanych w trumnach lub dranicowych obstawach przykrytych deską" (Kara 2017, s. 139). 
zakresie podlegały presji chrześcijaństwa ${ }^{42}$. Siłą rzeczy swym artystycznym wystrojem zawieszki te nie mogły odbiegać od norm i kanonów wyznaczanych przez nową wiarę, a tym bardziej stać $\mathrm{z}$ nimi $\mathrm{w}$ jawnej sprzeczności. Zapewne też umieszczone na nich motywy symboliczne były, przynajmniej w jakimś zakresie, rozpoznawalne przez swe użytkowniczki (Zawol 2018, s. 484). Możliwe nawet, że stawały się mnemonicznym elementem służącym chrześcijańskiej edukacji i wychowaniu ${ }^{43}$, i to już od najmłodszych lat, jeśli wziąć pod uwagę, że z kaptorgami chowano także dzieci. Nieprzypadkowo też wiele okazów pochodzi z cmentarzy powiązanych osadniczo z ważnymi dla rodzącej się państwowości polskiej i przemian zachodzących w kulturze religijnej ośrodkami administracyjno-kościelnymi (w pierwszej kolejności Dziekanowice, Giecz, Radom, Poznań, Opole, Sandomierz).

Poza zasięgiem wzroku, w miejscu niedającym się łatwo kontrolować, znajdowała się natomiast zawartość omawianych zawieszek. Niewykluczone, że wkładano do nich wspomniane pararelikwie, ale równie dobrze mogły to być składniki służące magii leczniczej i ochronnej, zwłaszcza pochodzenia roślinnego (por. Vida 2009, s. 270), stosowane na „prywatny” użytek. Niekoniecznie zatem wnętrze

${ }^{42}$ Archeologicznie uchwytnym tego świadectwem zdaje się zjawisko licznego występowanie dewocjonaliów, zwłaszcza różnego typu krzyżyków, we wczesnośredniowiecznych pochówkach kobiecych, z wielu regionów europejskich, w tym terenów Polski (Wołoszyn 2003). Warto wszakże dopowiedzieć, iż zależność ta wiąże się z ogólnie obserwowaną tendencją częstszego aniżeli mężczyzn chowania kobiet (także dzieci) z amuletami (zob. np. Dübner-Manthey 1990; Vida 1995; Nedoshivina 1997; Chorvátová 1998), odwołującą się do zachowań magicznych. Według I. Štefana, zawieszki w postaci krzyża również należy postrzegać jako apotropaiony. Badacz ten powołał się tu na zespół złożonego z kaptorgi i ołowianych krzyżyków jednego z grobów z Dolnich Vestonic. Pochowanemu w nim dziecku dano „ochronę” w postaci różnych przedmiotów o potencjale magicznym, a domysł, że należały one do dwóch odmiennych światów może być jedynie konstruktem naszego spolaryzowanego punktu widzenia (Štefan 2004, s. 42-43). Również H. Kóčka-Krenz zastanawiała się nad kwestią, czy krzyżyki z grobów odkrytych w Polsce, zwłaszcza wschodniej, każdorazowo manifestowały przynależność chrześcijańską pochowanych kobiet. Wątpliwości budzi współwystępowanie w koliach innych zawieszek-amuletów (np. zęby zwierzęce, muszle). „W takich wypadkach stanowią one raczej oznakę synkretyzmu religijnego, którego przejawy są uchwytne w elementach rytuału pogrzebowego omawianych czasów" (Kóčka-Krenz 2002, s. 161; zob. także Żółkowska 2010, s. 245, 247). O niejednoznacznej wymowie dewocjonaliów w grobach, skutkującej niewielką bądź żadną ich przydatnością jako wyznaczników formacji religijnej pochowanych z nimi osób, przekonani są inni badacze (zob. np. Staecker 1997, s. 444-445; Buko 2016, s. 46). Nieco odmienne stanowisko zajął Š. Ungerman. W jego opinii wspomniany zestaw przedmiotów dolnovestonickich był pośmiertnym darem rodziców, którzy uważali się za chrześcijan, chociaż wiele ich praktyk musiało wzbudzać sprzeciw ówczesnych władz kościelnych (Ungerman 2007, s. 231). Same zaś krzyżyki wskazywały nie tylko na chrześcijańską przynależność właściciela, ale jednocześnie były ważnym środkiem ochronnym przed siłami zła (Ungerman 2007, s. 231). Dla ukazania złożoności omawianego zagadnienia warto dopowiedzieć, że w grobie $\mathrm{nr} 57 / 59 \mathrm{w}$ Lahovicach na kolii oprócz trapezowatej kaptorgi i paciorków zawieszona była - jako kolejny amulet - wygładzona kość ptasia (Krumphanzlová 1963, s. 102).

${ }^{43}$ Zapatrywania średniowiecznych myślicieli na naturę jako emanację Bożej doskonałości i harmonii, zawarte w pełnych odniesień symbolicznych realizacjach artystycznych (zob. Jakóbczyk-Gola 2013, s. 83-85), wydają się „sytuować motyw zoomorficzny w podwójnej roli - jako środka umożliwiającego poznanie prawd ponadnaturalnych i dydaktyczno-objaśniające exemplum służące nauce i poznaniu, ale w równym stopniu kształtujące postawy życiowe i etyczne" (Solik 2003, s. 70). 
kaptorgi w swej wymowie przystawało do ikonograficznego programu uwidocznionego na przedmiocie ${ }^{44}$. A zarazem nawet jeśli zdawano sobie sprawę z chrześcijańskiego sensu znajdującego się na zawieszce przedstawienia czy z takowym je kojarzono, nie musiało to być odczuwane jako sprzeczność względem ochronnej roli zawartości, a wręcz przeciwnie - jako wzmocnienie jej znaczenia (zob. Profantová i Daněček 2017, s. 108). Różnego rodzaju relikwiom dawanym we wczesnym średniowieczu do grobów na równi przypisywano moc wstawienniczą ze strony świętych w dniu Sądu Ostatecznego, jak też magiczną i antydemoniczną, będącą rysem archaicznych wierzeń. Należy widzieć tu zatem dwie komplementarne strategie podejmowane wobec zmarłych (Jäggi 2016; zob. też Quast 2009). W porównywalny sposób chowanie zmarłych z kaptorgami pozwala sądzić, iż ich apotropaiczna funkcja wynikająca zarówno z wizerunku, jak i umieszczonego wewnątrz depozytu zachowywała swą aktualność także w grobie. Powyższe spostrzeżenia w porównywalnym stopniu odnoszą się do kaptorg zarówno prostokątnych, jak i trapezowatych, choć te pierwsze w literaturze często określane są jako ,schowki na amulety”45, w odróżnieniu od odmiany trapezowatej - „relikwiarzowej”, uznawanej za chronologicznie młodszą (Tabaczyński 1958, s. 19-21; Abramowicz 1962, s. 105; Wawrzeniuk 2016, s. 121) ${ }^{46}$. Później także one mogły przyjąć - w ślad za okazami trapezowatymi - nową funkcję (Kóčka-Krenz 1993, s. 165). Jak jednak wykazano, na ziemiach polskich obydwu form używano równolegle i nie można mówić o jakimś jasno zaznaczającym się następstwie czasowym ${ }^{47}$. Według H. Zoll-Adamikowej, słusznie podkreślającej niejednoznaczny charakter omawianej grupy wyrobów ,przy formułowaniu ostatecznych wniosków liczyć się będzie trzeba ze złożonymi zjawiskami synkretyzmu czy adaptacji starych form dla nowych treści, bądź też generalnej zmiany zarówno kształtu, techniki, jak i funkcji kaptorg (z jednej odmiany na drugą) w ramach akceptacji nowej religii” (Zoll-Adamikowa 1971, s. 98; zob. także Štefan 2004, s. 46). Bez względu na przyjmowany i forsowany kierunek interpretacji znaczenia tej kategorii wyrobów złotniczych (,pogański” czy

${ }^{44} \mathrm{~W}$ tym miejscu godne wzmianki są zachodnioeuropejskie metalowe schowki zdobione motywami chrześcijańskimi, ale jednocześnie zawierające pozostałości roślinne, np. złota kapsułka z symbolem krzyża (VII wiek) znaleziona wewnątrz kamiennego sarkofagu w miejscowości Horbourg-Wihr (niem. Horburg-Weier, Alzacja), w której znajdowały się resztki goździka (Caryophyllum aromatica) i grudki kadzidła (Lucchesi Palli 1994, s. 176). Nie wyklucza się wszakże związku zawartości tego przedmiotu z kultem chrześcijańskim (dyskusja w Shellhas 1994, s. 93-95).

45 Pokrewne funkcjonalno i znaczeniowo byłyby tekstylne - wełniane, niekiedy też jedwabne oraz skórzane woreczki (Gdańsk, Opole-Ostrówek, Wrocław-Ostrów Tumski, Wolin), a także zawieszki wykonane z drewna (Wolin). W X-XIII wieku służyły one do przechowywaniu amuletów, ewentualnie drobnych przedmiotów (Jaguś 2003, s. 12; Wawrzeniuk 2016, s. 120, 330-332; Grupa 2017; Kajkowski 2019, s. 247). Być może nosiła je ludność uboższa (Tabaczyński 1958, s. 26; Sztyber 2010, s. 56; zob. także Štefan 2014, s. 45-46), choć raczej nie dotyczyło to wyrobów jedwabnych (Hensel 1987 , s. 595).

${ }^{46}$ W konsekwencji kaptorgami bywają nazywane tylko okazy trapezowate (Kostrzewski 1955, s. $284-285 ; 1969$, s. 160 - w pracach tych na rycinach okazy prostokątne są jednakże podpisane jako kaptorgi; Jaguś 2003, s. 12).

${ }^{47}$ Najlepiej pokazuje to zróżnicowany typologicznie zespół kaptorg z grobu dziekanowickiego. 
„chrześcijański”) w nowszej literaturz również dopuszcza się możliwość przenikania się dawnej obrzędowości z rytualnymi wymogami nowej wiary (Zawol 2018, s. 485; Kajkowski 2019, s. 250; por. Vida 2009).

\section{PODSUMOWANIE}

Rekapitulując dotychczasowe rozważania, podkreślić należy, iż badania cmentarzyska w Radomiu dostarczyły kolejnych znalezisk kaptorg, będących elementem wyposażenia pośmiertnego. Poszerza to niedługą listę znanych dotąd okazów pochodzących z wczesnośredniowiecznych grobów odkrytych na terenie ziem polskich, a jednocześnie wzbogaca wiedzę na temat tego rodzaju wyrobów. Do najistotniejszych ustaleń należy określenie surowca, z którego obydwie kapsułki wykonano (mosiądz), z czym tylko sporadycznie mieliśmy dotąd do czynienia w grupie omawianych zawieszek. Wykorzystanie takiego materiału mogło wynikać z chęci upodobnienia do wyrobów wykonanych ze szlachetniejszych kruszców. Inną ważną cechą kaptorg radomskich jest sposób zdobienia, który również nie ma bezpośrednich analogii $\mathrm{w}$ materiałach $\mathrm{z}$ ziem polskich. Analizowane zawieszki wraz z innymi elementami inwentarza grobowego, w tym także z przedmiotami pochodzącymi sprzed wczesnego średniowiecza oraz archeologiczny kontekst ich odkrycia (skala założenia grobowego) wskazują na dość wyjątkowy wizerunek społeczny pochowanej kobiety. Potwierdza to obserwacje poczynione wobec innych pochówków zawierających kaptorgi. Można sądzić, że odkryte w Radomiu zawieszki pełniły funkcję schowków na amulety lub - ze znacznie mniejszym prawdopodobieństwem - relikwie kontaktowe bądź pachnidła (ich funkcja mogła być zresztą zbieżna i komplementarna), aczkolwiek ewentualna pierwotna zawartość pozostaje nieznana (brak przesłanek, by łączyć z nią pestki winorośli). Do grobu kaptorgi te najprawdopodobniej dostały się po połowie XI wieku - w okresie transformacji religijnej zachodzącej w państwie wczesnopiastowskim, dając materialne świadectwo przenikania się starego i nowego porządku.

\section{BIBLIOGRAFIA}

Abramowicz A. 1962, Studia nad geneza polskiej kultury artystycznej, Łódź-Warszawa, Państwowe Wydawnictwo Naukowe.

Anders J. 2013, Früh- und hochmittelalterliche Flussfunde in Norddeutschland. Das Material aus Peene, Recknitz, Tollense und Trebel und seine siedlungsgeschichtliche Einbindung, „Studien zur Archäologie Europas“ 19, Bonn, Verlag Dr. Rudolf Habelt GmbH.

Andrałojć M., Andrałojć M., Tuszyński M. 2005, Wczesnośredniowieczny skarb z Kąieli, gm. Czerniejewo, Poznań, Wydawnictwo PTPN.

Androshchuk F.A. 2013, Ibn Fadlan i ukrasheniya rusov, w: G.Yu. Ivakin (red.), Slov'yany i Rus': arkheolohiya ta istoriya. Zbirka prats' na poshanu diysnoho chlena Natsional'noyi akademiyi nauk Ukrayiny Petra Petrovycha Tolochka z nahody yoho 75-richchya, Kyyiv, Starodavniy Svit, s. 17-27. 
Arbman H. 1940, Birka I. Die Gräber. Tafeln, Uppsala, Kungl. Vitterhets Historie och Antikvitets Akademien.

- 1943, Birka I. Die Gräber. Text, Uppsala Kungl. Vitterhets Historie och Antikvitets Akademien.

Arents U., Eisenschmidt S. 2010a, Die Gräber von Haithabu 1. Text, Literatur, Neumünster, Wachholtz Verlag.

- 2010b, Die Gräber von Haithabu, 2. Katalog, Listen, Tafeln, Beilagen, Neumünster, Wachholtz Verlag.

Augustyniak J. (red.) 2000, Najstarsze skarby chrześcijańskiego dziedzictwa Polski, Łódź 20 XII 1999 - 31 I 2000. Katalog wystawy, Łódź, Archidiecezjalne Wydawnictwo Łódzkie.

Bagnoli M. 2014, Dressing the Relics. Some Thoughts on the Custom of Relic Wrapping in Medieval Christianity, w: J. Robinson, L. de Beer, A. Harnden (red.), Matter of Faith: An Interdisciplinary Study of Relics and Relic Veneration in the Medieval Period, London, The British Museum, s. 100-109.

Banaszak D., Tabaka A. 2017, Equs aureus - fragment zlotej kaptorgi z wizerunkiem konia z Ostrowa Lednickiego, w: A. Różański (red.), Gemma Gemmarum. Studia dedykowane Profesor Hannie Kóčce-Krenz 2, Poznań, Wydawnictwo PTPN, s. 1199-1206.

- 2020, Ślady wierzeń pogańskich na przykładzie znalezisk z Ostrowa Lednickiego, „Slavia Antiqua” 61, s. 117-134.

Bąbel J.T. 2004, Smoki Europy, w: A. Motycka, K. Maurin (red.), Symbole Europy. Integracja jako proces psychologiczny i kulturowy, Warszawa, Wydawnictwo ENETEIA, s. 21-37.

Bintley M.D.J. 2011, The Byzantine Silver Bowls in the Sutton Hoo Ship Burial and Tree-Worship in Anglo-Saxon England, "Papers from the Institute of Archaeology" 21, s. 34-45.

Błaszczyk D. 2015-2016, Pochodzenie i dieta mężczyzny pochowanego w grobie D162 z cmentarzyska w Bodzi w świetle badań izotopowych, „Światowit” 13-14(54-55)/A-B, s. 130-157.

- 2020a, Wyposażenie zmarlych / Grave goods, w: D. Poliński (red.), Wczesnośredniowieczne i nowożytne cmentarzysko w Pniu / Early medieval and early modern burial site in Pień, Toruń, Europejska Fundacja „Pamięć i Dziedzictwo”, Instytut Archeologii UMK, s. 89-142.

- 2020b, Chronologia / Chronology, w: D. Poliński (red.), Wczesnośredniowieczne i nowożytne cmentarzysko w Pniu / Early medieval and early modern burial site in Pień, Toruń, Europejska Fundacja „Pamięć i Dziedzictwo”, Instytut Archeologii UMK, s. 142-146.

Błaszczyk D., Drozd-Lipińska A., Poliński D. 2020, Katalog grobów / List of graves, w: D. Poliński (red.), Wczesnośredniowieczne i nowożytne cmentarzysko w Pniu / Early medieval and early modern burial site in Pień, Torun, Europejska Fundacja „Pamięć i Dziedzictwo”, Instytut Archeologii UMK, s. 297-353.

Bojarski J. 2014, Atrybuty władzy na przykładzie grobów z wczesnośredniowiecznego cmentarzyska w Napolu, woj. kujawsko-pomorskie, w: W. Dzieduszycki, J. Wrzesiński (red.), Królowie i biskupi, rycerze i chtopi-identyfikacja zmarlych, Funeralia Lednickie 16, Poznań, SNAP Oddział w Poznaniu, s. 173-186.

Bojarski J., Chudziak W., Drozd A., Koperkiewicz A., Kozłowski T., Stawska V. 2010, Katalog źródeł, w: W. Chudziak (red.), Wczesnośredniowieczne cmentarzysko szkieletowe w Katdusie (stanowisko 4), Mons Sancti Laurentii 5, Toruń, Instytut Archeologii UMK, s. 189-603.

Borowska-Strugińska B., Kapla W. 2020, Analiza antropologiczna szczątków kostnych populacji wczesnośredniowiecznej. Katalog, w: T. Baranowski, K. Skrzyńska, K. Skóra (red.), Stanowisko 4: Badania interdyscyplinarne, Przestrzeń osadnicza wczesnośredniowiecznego Radomia 3, Łódź-Warszawa, Wydawnictwo IAE PAN, s. 59-102.

Brather S. 2008, Archäologie der westlichen Slawen. Siedlung, Wirtschaft und Gesellschaft im früh- und hochmittelalterlichen Ostmitteleuropa, Ergänzungsbände zum Reallexikon der Germanischen Altertumskunde 61, Berlin-New York, Walter de Gruyter.

Buko A. 2016, Chrześcijanie i poganie. O problemach interpretacji odkryć archeologicznych zwiqzanych z poczatkami chrześcijaństwa na ziemiach polskich, „Slavia Antiqua” 57, s. 13-51.

Chorvátová H. 1998, K významu príveskov-amuletov z včasnostredovekých pohrebísk, „Hieron” 3, s. 106-112.

Chudziak W. 2001, Wczesnośredniowieczne groby komorowe z Kałdusa pod Chetmnem na Pomorzu Wschodnim, „Slavia Antiqua” 42, s. 63-96. 
Chudziak W., Bojarski J., Stawska V. 2010a, Wyposażenie pochówków, w: W. Chudziak (red.), Wczesnośredniowieczne cmentarzysko szkieletowe w Kałdusie (stanowisko 4), Mons Sancti Laurentii 5, Toruń, Instytut Archeologii UMK, s. 79-103.

- 2010b, Chronologia cmentarzyska, w: W. Chudziak (red.), Wczesnośredniowieczne cmentarzysko szkieletowe w Kałdusie (stanowisko 4), Mons Sancti Laurentii 5, Torun, Instytut Archeologii UMK, s. $105-120$.

Cichońska J. 2017, Nowe znaleziska z cmentarzyska z grobami w obudowach kamiennych w Żukowie, w: M. Dzik, G. Śnieżko (red.), Fines testis temporum. Studia ofiarowane Elżbiecie Kowalczyk-Heyman w pięćdziesięciolecie pracy naukowej, Rzeszów, Instytut Archeologii Uniwersytetu Rzeszowskiego, Instytut Archeologii Uniwersytetu Warszawskiego, Polskie Towarzystwo Historyczne, Towarzystwo Miłośników Historii, Wydział Historyczny Uniwersytetu Warszawskiego, s. 325-337.

Corsten M. 1991, Die buchförmigen Anhänger des frühen Mittelalters - Ein Beitrag zur Amulettforschung, „Fornvännen” 86, s. 183-189.

Czonstke K. 2009-2010, Biżuteria stowiańska z wczesnośredniowiecznych skarbów bornholmskich, „Materiały Zachodniopomorskie. Nowa Seria" 6-7(1), s. 167-202.

- 2018, Biżuteria słowiańska w basenie Morza Battyckiego we wczesnym średniowieczu, „Pomorania Antiqua" 27, s. 95-108.

Czonstke K., Koperkiewicz A. 2013, Biżuteria ze skarbu w Olbrachtówku, w: J. Sobieraj (red.), Średniowieczne skarby srebrne z Pojezierza Itawskiego w zbiorach Muzeum Warmii i Mazur, Olsztyn, Muzeum Warmii i Mazur, s. 221-252.

Davy M.-M. 2011, Symbolika romańska (XII w.), Warszawa, Oficyna Wydawnicza Volumen.

Dobrodomov I.G. 2008, Drevnerusskiy gapaks kaptorga v leksikograficheskom i etimologicheskom osveshchenii, ,Vestnik Pravoslavnogo Svyato-Tikhonovskogo gumanitarnogo universiteta”, seria 3 (Filologiya) 1(11), s. 18-26.

Drozd A. 2006, Biżuteria i części stroju, w: W. Chudziak (red.), Wczesnośredniowieczne cmentarzysko szkieletowe w Katdusie (stanowisko 1), Mons Sancti Laurentii 3, Toruń, Instytut Archeologii UMK, s. 67-84.

Drozd A., Janowski A., Poliński D. 2009, Wczesnośredniowieczne groby komorowe na cmentarzysku w Pniu koło Bydgoszczy (badania 2005-2007), w: A. Janowski, K. Kowalski, S. Słowiński (red.), XVI Sesja Pomorzoznawcza Szczecin 22-24 listopada 2007 r. 1, Acta Archaeologica Pomoranica 3, Szczecin, SNAP Oddział w Szczecinie, Muzeum Narodowe w Szczecinie, Muzeum w Stargardzie, s. 351-366.

- 2011, Badania ratownicze przeprowadzone w 2009 roku na średniowieczno-nowożytnym cmentarzysku w Pniu, gm. Dąbrowa Chetmińska, woj. kujawsko-pomorskie (stanowisko 9), w: M. Fudziński, H. Paner (red.), XVII Sesja Pomorzoznawcza 1, Gdańsk, Muzeum Archeologiczne w Gdańsku, s. 513-521.

Dübner-Manthey B. 1990, Zum Amulettbrauchtum in frühmittelalterlichen Frauen- und Kindergräbern, w: W. Affeldt (red.), Frauen in Spatantike und Frühmittelalter. Lebensbedingungen - Lebensnormen - Lebensformen, Sigmaringen, Jan Thorbecke Verlag, s. 65-87.

Duczko W. 1972, Slavic silver jewellery from the Viking Period. An analysis of material from Gotland, C-uppsats i arkeologi, Uppsala, Uppsala Universitet.

- 1985, Birka V. The filigree and granulation work of the Viking Period. An analysis of the material from Björko, Stockholm Kungl. Vitterhets Historie och Antikvitets Akademien.

- 2016, Status i magia. Ozdoby elit z Bodzi, w: A. Buko (red.), Bodzia. Elitarny cmentarz z początków państwa polskiego, Warszawa, Wydawnictwo IAE PAN, s. 131-151.

- 2018, Post-wielkomorawski fenomen. Wczesnośredniowieczna sztuka złotnicza w środkowej $i$ wschodniej Europie, w: B. Gediga, A. Grossman, W. Piotrowski (red.), Inspiracje i funkcje sztuki pradziejowej $i$ wczesnośredniowiecznej, Biskupin-Wrocław, Muzeum Archeologiczne w Biskupinie, Polska Akademia Nauk - Oddział we Wrocławiu, s. 535-547.

Dzieduszycki W. 1995, Kruszce w systemach wartości i wymiany społeczeństwa Polski wczesnośredniowiecznej, Poznań, Wydawnictwo IAE PAN.

Eniosova N., Pushkina T. 1997, Some technological aspects of fine metalworking in Gnezdovo: an analysis of the hoards from the Upper Dnieper region, w: G. De Boe, F. Verhaeghe (red.), Art and Sym- 
bolism in Medieval Europe. Papers of the 'Medieval Europe Brugge 1997' Conference 5, Zellik, Instituut voor het Archeologisch Patrimonium, s. 65-71.

Evans H.C., Wixom W.D. (red.) 1997, The Glory of Byzantium. Art and Culture of the Middle Byzantine Era A.D. 843-1261, New York, The Metropolitan Museum of Art.

Firlet E., Zaitz E. (red.) 2006 Kraków w chrześcijańskiej Europie X-XIII w. Katalog wystawy, Kraków, Muzeum Historyczne Miasta Krakowa.

Forstner D. 1990, Świat symboliki chrześcijańskiej, Warszawa, Instytut Wydawniczy PAX.

Frolík J. 2013, Pohřebiště v Lumbeho zahradě, analýza, chronologie, význam, w: J. Frolík (red.), Pohřebiště v Lumbeho zahradě na Pražském hradě 2. Studie, Castrum Pragense 12, Praha, Archeologický ústav AV ČR, s. 5-115.

Frolíková D., Ottenwelter E., Barčáková L. 2020, A child burial with a necklace from the Triangle cemetery in Prague-Střě̌ovice, "Archeologické rozhledy" 72(2), s. 260-290.

Gabriel I. 1988, Hof- und Sakralkultur sowie Gebrauchs- und Handelsgut im Spiegel der Kleinfunde von Starigard/Oldenburg, „Bericht der Römisch-Germanischen Kommission“ 69, s. 103-291.

Gan P., Pawlicka E. 2020, Wyniki analizy chemicznej przedmiotów metalowych z cmentarzyska, w: T. Baranowski, K. Skrzyńska, K. Skóra (red.), Stanowisko 4: Badania interdyscyplinarne, Przestrzeń osadnicza wczesnośredniowiecznego Radomia 3, Łódź-Warszawa, Wydawnictwo IAE PAN, s. 197-205.

Gapski H. 2014, Koń w kulturze polskiego średniowiecza, Poznań, Wydawnictwo Nauka i Innowacje.

Gardeła L., Kajkowski K. Ratajczyk Z. 2019, Ostrogi zoomorficzne z Ciepłego. Zachodniosłowiański model kosmologiczny?, „Pomorania Antiqua” 28, s. 65-152.

Gągorowska-Chudobska J. 2013, Wczesnośredniowieczny skarb srebrny z Czerniejewa w zbiorach Muzeum Narodowego w Kielcach, „Rocznik Muzeum Narodowego w Kielcach” 28, s. 305-325.

Gąssowska E. 1979, Bizancjum a ziemie pótnocno-zachodnio-stowiańskie we wczesnym średniowieczu. Studium archeologiczne, Wrocław-Warszawa-Kraków-Gdańsk, Zakład Narodowy im. Ossolińskich, Wydawnictwo PAN.

Gąssowski J. 1950-1951, Wczesnohistoryczne cmentarzysko szkieletowe w Radomiu, „Wiadomości Archeologiczne" 17(4), s. 305-326.

- 1969, Materiały do osadnictwa wczesnośredniowiecznego Sandomierszczyzny, „Materiały Wczesnośredniowieczne" 6, s. 303-473.

- 1993, Między pogaństwem a chrześcijaństwem, w: M. Kwapiński, H. Paner (red.), Wierzenia przedchrześcijańskie na ziemiach polskich, Gdańsk, Muzeum Archeologiczne w Gdańsku, s. 12-18.

Gierszewska M. 2012, Smoki jako istoty mieszane. Funkcjonowanie $w$ literaturze greckiej $i$ rzymskiej, „Symbolae Philologorum Posnaniensium Graecae et Latinae” 22(1), s. 167-186.

Goslar T. 2016, Wyniki kalibrowanych datowań radiowęglowych prób z cmentarzyska w Bodzi wykonanych $w$ Poznańskim Laboratorium Radiowęglowym metoda ${ }^{14}$ C AMS, w: A. Buko (red.), Bodzia. Elitarny cmentarz z początków państwa polskiego, Warszawa, Wydawnictwo IAE PAN, s. 453-454.

Górecki J. 2009, U źródel chrześcijaństwa w Polsce - relikwiarz Drzewa Świętego Krzyża z Ostrowa Lednickiego, w: A.M. Wyrwa (red.), Stauroteka lednicka. Materiaty, studia $i$ analizy, Lednica-Poznań, Muzeum Pierwszych Piastów na Lednicy, s. 13-46.

- 2013, Ze studiów nad zagadnieniem napływu przedmiotów proweniencji bizantyńskiej na ziemie Polski na przykładzie Ostrowa Lednickiego, „Archeologia Polski” 58(1-2), s. 89-114.

Grupa D. 2017, Wetniane woreczki jako wyraz magicznych zachowań wczesnośredniowiecznych mieszkańców osady rzemieślniczo-rybackiej w Gdańsku, „Acta Universitatis Nicolai Copernici. Archeologia" 25, s. 101-112.

Grygiel R. 2014, Cmentarzysko wareskich drużynników w Lutomiersku, w: R. Grygiel, T. Jurek (red.), Początki Łęczycy 2, Łódź, Muzeum Archeologiczne i Etnograficzne w Łodzi, s. 679-757.

Grzegorczyk A. 2009, Występowanie i funkcja wczesnośredniowiecznych kaptorg z terenu ziem polskich, „In Tempore” 2009, s. 1-10.

Hart Ch. 2016, An Analysis of the Iconographic Rosette Motif as a Means of Non-Verbal Communication: A Case Study - The Rosette Motif and its Association with Solar Symbolism, w: R.A. Stucky, O. Kaelin, H.-P. Mathys (red.), Proceedings of the 9th International Congress on the Archaeology of the Ancient Near East, 9-13 June 2014, Basel 1, Wiesbaden, Harrassowitz Verlag, s. 125-135. 
Hensel W. 1987, Stowiańszczyzna wczesnośredniowieczna. Zarys kultury materialnej, Warszawa, Państwowe Wydawnictwo Naukowe.

Hensel Z. 2016, Badania materiałoznawcze wybranych znalezisk z cmentarzyska w Bodzi, w: A. Buko (red.), Bodzia. Elitarny cmentarz z początków państwa polskiego, Warszawa, Wydawnictwo IAE PAN, s. 305-317.

Hensel Z., Wrzesińska A., Kaliński W., Pawlicka E., Pogorzelska E. 2019, Materiałoznawcze badania ozdób ze stanowiska Dziekanowice 22, w: J. Wrzesiński (red.), Groby z biżuteriq wczesnośredniowiecznego cmentarzyska w Dziekanowicach 2, Biblioteka Studiów Lednickich Fontes 8:2, Lednica, Muzeum Pierwszych Piastów na Lednicy, s. 391-461.

Herrmann J., Lange E. 1982, Die Pferde von Arkona. Zur Frage der Pferdehaltung und Pferdezucht bei den slawischen Stämme zwischen Elbe und Oder, "Beiträge zur Ur- und Frühgeschichte" 2, s. 125-133.

Heyerdahl-Larsen B. 1982, „, Gnotiske” amulettgjemmer i statten fra Hon?, „Viking“ 45, s. 93-104.

Holc E. 2005, Opole-Groszowice, w: E. Tomczak (red.), Skarby ziemi wydarte. Górny Ślask i pogranicze, Katowice, Śląskie Centrum Dziedzictwa Kulturowego w Katowicach, s. 106.

Hołowińska Z. 1959, Wczesnośredniowieczne rzemiosło zlotnicze w Gdańsku, w: J. Kamińska (red.), Gdańsk Wczesnośredniowieczny 1, Gdańsk, Gdańskie Towarzystwo Naukowe, s. 55-105.

Honneger Th. 2019, Introducing the medieval dragon, Cardiff, University of Wales Press.

Ibn Fadlān 1985, Kitāb, w: Źródła arabskie do dziejów Stowiańszczyzny 3, oprac. A. Kmietowicz, F. Kmietowicz, T. Lewicki, Wrocław-Warszawa-Kraków-Gdańsk-Łódź, Zakład Narodowy im. Ossolińskich.

Indycka E. 2009, Bransoleta srebrna o końcach w wężowe główki, w: J. Górecki (red.), 40 zabytków. Katalog wystawy jubileuszowej z okazji 40-lecia Muzeum Pierwszych Piastów na Lednicy, Lednica, Muzeum Pierwszych Piastów na Lednicy, s. 32.

- 2016, Cmentarz przy wczesnośredniowiecznym grodzie w Gieczu, w: M. Kara, T. Krysztofiak, A.M. Wyrwa (red.), Gród piastowski w Gieczu. Geneza - funkcja - kontekst, Poznań, Wydawnictwo PTPN, s. 209-237.

Jäggi C. 2016, Heiliges für die Reise ins Jenseits. Reliquien und Apotropaia als Grabbeigaben, w: C. Alraum, A. Holndonner, H.-Ch. Lehner, C. Scherer, Th. Schlauwitz, V. Unger (red.), Zwischen Rom und Santiago. Festschrift für Klaus Herbers zum 65. Geburtstag. Beiträge seiner Freunde und Weggefähren, dargereicht von seinen Schülerinnen und Schülern, Bochum, Verlag Dr. Dieter Winkler, s. 227-237.

Jaguś J. 2003, Uwagi na temat wymowy magicznej średniowiecznych amuletów i ozdób na ziemiach polskich, „Annales Universitatis Mariae Curie-Skłodowska”, sectio F - Historia 58, s. 7-24.

Janowski A. 2011, Grodzisko wczesnośredniowieczne w Lubinie koło Gryfic. Wyniki badań w 2007 roku w: M. Fudziński, H. Paner (red.), XVII Sesja Pomorzoznawcza 1, Gdańsk, Muzeum Archeologiczne w Gdańsku, s. 471-477.

- 2014, Przestrzeń rozświetlona. Znaleziska świec i wosku w grobach komorowych na terenie Europy Środkowowschodniej, w: T. Kurasiński, K. Skóra (red.), Grób w przestrzeni, przestrzeń w grobie. Przestrzenne uwarunkowania $w$ dawnej obrzędowości pogrzebowej, „Acta Archaeologica Lodziensia" 60, Łódź, Łódzkie Towarzystwo Naukowe, s. 121-130.

- 2015, Groby komorowe w Europie Środkowo-Wschodniej. Problemy wybrane, Szczecin, Ośrodek Archeologii Średniowiecza Krajów Nadbałtyckich IAE PAN.

Jakimowicz R. 1933, O pochodzeniu ozdób srebrnych znajdowanych w skarbach wczesnohistorycznych, „Wiadomości Archeologiczne” 12, s. 103-138.

- 1939 Nowe materiały do dziejów złotnictwa wczesnopolskiego, „Wiadomości Archeologiczne” 16, s. 378-386.

Jakóbczyk-Gola A. 2013, Encyklopedia pamięci. Dwunastowieczna rzeźba w Polsce jako forma pamięci kulturowej, w: M. Prejs, A. Jakóbczyk-Gola (red.), Mnemonika i pamięć kulturowa epok dawnych, Warszawa, Wydawnictwo Neritum, s. 81-108.

Jażdżewski K. 1937, Dotychczasowe wyniki badań archeologicznych na Kujawach w roku 1937, „Z otchłani wieków" 12(7-8), s. 95-108.

- 1949, Cmentarzysko wczesnośredniowieczne w Lutomiersku pod Łodziq w świetle badań z r. 1949, „Materiały Wczesnośredniowieczne” 1, s. 91-191. 
Kajkowski K. 2016, Święty Wojciech, urbs Gyddaanyzc i problem chrystianizacji Pomorza Wschodniego. Kilka uwag na marginesie rozważań dotyczacych kultury duchowej mieszkańców grodu w widtach Wisty i Mottawy, „Komunikaty Mazursko-Warmińskie” 3(293), s. 431-455.

- 2019 Obrzędowość religijna Pomorzan we wczesnym średniowieczu. Studium archeologiczne, Wrocław, Wydawnictwo Chronicon.

Kajkowski K., Szczepanik P. 2012 Drobna plastyka figuralna wczesnośredniowiecznych Pomorzan. „Materiały Zachodniopomorskie. Seria Nowa" 9(1), s. 207-247.

Kara M. 2016, Organizacja przestrzeni grzebalnej, rytuat i obrzadek pogrzebowy, w: A. Buko (red.), Bodzia. Elitarny cmentarz z początków państwa polskiego, Warszawa, Wydawnictwo IAE PAN, s. 329-380.

- 2017, Wczesnośredniowieczne cmentarzysko z Poznania-Sołacza przy ul. Góralskiej nr 7, w: A. Różański (red.), Gemma Gemmarum. Studia dedykowane Profesor Hannie Kóčce-Krenz 1, Poznań, Wydawnictwo PTPN, s. 131-161.

Kars M. 2013, The early-medieval burial evidence and concepts of possession: questioning individual identities. w: B. Ludowici (red.), Individual and Individuality? Approaches towards an Archaeology of Personhood in the First Millennium AD, Neue Studien zur Sachsenforschung 4, Hannover, Niedersächsisches Landesmuseum, s. 95-106.

Kaszewska E. 1960, Wczesnośredniowieczne cmentarzysko w Kałdusie pow. Chetmno (Badania w 1957 r.), „Prace i Materiały Muzeum Archeologicznego i Etnograficznego w Łodzi. Seria Archeologiczna” 5, s. $143-181$.

Kaszewscy E. i Z. 1971, Wczesnośredniowieczne cmentarzysko w Brześciu Kujawskim, pow. Włocławek, „Materiały Starożytne i Wczesnośredniowieczne” 1, s. 365-434.

Kaźmierczak R., Hildebrandt T. 2014, Jewellery and parts of costume, w: W. Chudziak, R. Kaźmierczak (red.), The Island in Żótte on Lake Zarańskie. Early Medieval Gateway into West Pomerania, Torun, Institute of Archaeology Nicolaus Copernicus University, s. 258-267.

Kaźmierczyk J. 1966, Komunikat z badań cmentarzyska i osady koło wsi Wszemirów powiat Trzebnica w 1966 roku, „Śląskie Sprawozdania Archeologiczne” 9, s. 36-37.

Kihl-Byczko E. 1970, W sprawie pochodzenia i funkcji kaptorg trapezowatych, w: W. Hensel (red.), I Międzynarodowy Kongres Archeologii Stowiańskiej, Warszawa 14-18 IX 1965 5, Wrocław-Warszawa-Kraków, Zakład Narodowy im. Ossolińskich, s. 423-428.

Klanica Z. 2010, Nález ozdob tvaru knižní vazby, w: Š. Ungerman, R. Přichystalová (red.), Zaměřena na stredověk. Zdeňkovi Měřinskému $k$ 60. narozeninám, Praha, Nakladatelství Lidové noviny, s. 184-193.

Kleingärtner S. 2015, The Cross-Shaped Pendant, w: J. Wrzesiński, A.M. Wyrwa (red.), Srebrny naszyjnik z kaptorgami i krzyżowata zawieszka z Dziekanowic, Lednica, Muzeum Pierwszych Piastów na Lednicy, s. 67-80.

Koktvedgaard Zeiten M. 1997, Amulets and Amulet Use in Viking Age Denmark, "Acta Archaeologica" 68 , s. 1-74.

Kołyszko M. 2019, Zawartość kaptorgi z grobu 28/01 - początki zwyczaju agnuska na terenie domeny piastowskiej?, w: J. Wrzesiński (red.), Groby z biżuteria wczesnośredniowiecznego cmentarzyska w Dziekanowicach 2, Biblioteka Studiów Lednickich Fontes 8:2, Lednica, Muzeum Pierwszych Piastów na Lednicy, s. 347-354.

Kordala T. 2006, Wczesnośredniowieczne cmentarzyska szkieletowe na pótnocnym Mazowszu, Łódź, Instytut Archeologii Uniwersytetu Łódzkiego.

Korzukhina G.F. 1954, Russkiye klady IX-XIII vv. Moskva-Leningrad, Izdatel'stvo Akademii Nauk SSSR.

Kostrzewski B. 1965, Kaptorgi, w: W. Kowalenko, G. Labuda, T. Lehr-Spławiński (red.), Stownik starożytności słowiańskich 2(2), Wrocław-Warszawa-Kraków, Zakład Narodowy im. Ossolińskich, Wydawnictwo PAN, s. 371-372.

Kostrzewski J. 1955, Wielkopolska w pradziejach, Warszawa-Wrocław, Zakład im. Ossolińskich.

- 1962, O pochodzeniu ozdób srebrnych z polskich skarbów wczesnośredniowiecznych, „Slavia Antiqua" 9, s. 139-211.

- 1969, Kultura prapolska, Warszawa, Państwowe Wydawnictwo Naukowe. 
Koszałka J. 2016, Analizy dendrologiczne i makroskopowe szczątków roślin, w: A. Buko (red.), Bodzia. Elitarny cmentarz z początków państwa polskiego, Warszawa, Wydawnictwo IAE PAN, s. 95-97.

Košnar L. 1991, Ke vztahüm mezi vikinským a západoslovanským prostředím, „Praehistorica” 18, s. 25-84.

Kowalczyk M. 1968, Wierzenia pogańskie za pierwszych Piastów, Łódź, Wydawnictwo Łódzkie.

Kóčka-Krenz H. 1993, Biżuteria pótnocno-zachodnia we wczesnym średniowieczu, Poznań, Wydawnictwo Naukowe UAM.

- 1995, Kaptorgi i kabłaczki skroniowe z wczesnośredniowiecznego grobu w Parchankach, gm. Dabrowa Górnicza, woj. bydgoskie (stan. 25), „Folia Praehistorica Posnaniensia” 7, s. 275-280.

- 2002, Krzyżyki we wczesnym średniowieczu jako przejaw chrystianizacji ziem polskich. Refleksja archeologa, w: F. Lenort (red.), Scirptura Sacra Posnaniensis. Opuscula Mariano Wolniewicz octogenario dedicata, Poznań, Wydział Teologiczny UAM, s. 153-161.

- 2014, Wczesnośredniowieczna biżuteria zachodniosłowiańska, „Studia Lednickie” 13, s. 27-38.

Kóčka-Krenz H., Pawlak P., Sikorski A. 1995, Grób kobiety z wczesnośredniowiecznego cmentarzyska szkieletowego w Poznaniu-Śródce (przyczynek do interpretacji funkcjonalnej kaptorg), „Folia Praehistorica Posnaniensia" 7, s. 281-294.

Krumphanzlová Z. 1963, Př́spěvek k vývoji lidového šperku 10. stol. v Čechách, „Památky archeologické" 54(1), s. 87-113.

- 1971, Počátky křestanství v Čechách ve svétle archeologických pramenů, „Památky archeologické” 62(2), s. 406-456.

Krzyszowski A., Silska P. 2006, Badania archeologiczne na Nizinie wielkopolsko-kujawskiej sezony 2004-2005. Wystawa kwiecień-czerwiec 2006, Poznań, Muzeum Archeologiczne w Poznaniu.

Kucypera P. 2014, Spectral analysis of non-ferrous metal objects, w: W. Chudziak, R. Kaźmierczak (red.), The Island in Żótte on Lake Zarańskie. Early Medieval Gateway into West Pomerania, Torun, Institute of Archaeology Nicolaus Copernicus University, s. 509-516.

Kurasiński T. 2010, Pochówki dzieci z wczesnośredniowiecznego cmentarzyska szkieletowego w Lubieniu (charakterystyka wstępna), w: W. Dzieduszycki, J. Wrzesiński (red.), Tak więc po owocach ich poznacie, Funeralia Lednickie 12, Poznań, SNAP Oddział w Poznaniu, s. 321-332.

Kurasiński T, Skóra K. 2012, Wczesnośredniowieczne cmentarzysko szkieletowe w Lubieniu, pow. piotrkowski, Łódź, Ośrodek Badań nad Dawnymi Technologiami IAE PAN.

- 2013, A będziecie jedli owoce ze swej winorośli... O szczatkach roślinnych z wczesnośredniowiecznego cmentarzyska w Radomiu, stan. 4, w: J. Kolenda, A. Mierzwiński, S. Moździoch, L. Żygadło (red.), Z badań nad kultura spoleczeństw pradziejowych i wczesnośredniowiecznych. Księga jubileuszowa dedykowana Profesorowi Bogusławowi Gedidze, w osiemdziesiata rocznice urodzin przez przyjaciól, kolegów i uczniów, Wrocław, Ośrodek Badań nad Kulturą Późnego Antyku i Wczesnego Średniowiecza IAE PAN, s. 637-648.

- 2015, Children's burial from the early medieval inhumation cemetery in Radom, site 4, "Fasciculi Archaeologiae Historicae" 28, s. 41-52.

- 2016, Cmentarzysko w Radomiu, stanowisko 4, Przestrzeń osadnicza wczesnośredniowiecznego Radomia 1, Łódź, Wydawnictwo IAE PAN.

Kurnatowska Z., Kara M. 2005, Na tropie Poznania - eponima naszego miasta, w: Z. Kurnatowska, T. Jurek (red.), Civitas Posnaniensis. Studia z dziejów średniowiecznego Poznania, Poznań, Wydawnictwo PTPN, s. 9-26.

Kuś A. 2007, Wróg ksiązęcego ładu - smoki, gryfy, lwy i inne bestie w systemie sfragistycznym Piastów, w: J. Olko, P. Prządka-Giersz (red.), Wyobrażenie wroga w dawnych kulturach, Warszawa, Wydawnictwo DiG, s. 175-183.

Lennartsson M. 1997-1998, Karolingische Metallarbeiten mit Pflanzenornamentik, "Offa" 54-55, s. 431-619.

Lepówna B. 1981, Materialne przejawy wierzeń ludności Gdańska w X-XIII w., „Pomorania Antiqua” 10, s. 169-199.

Lewicka-Rajewska U. 2004, Arabskie opisanie Stowian. Źródła do dziejów średniowiecznej kultury, Wrocław, Polskie Towarzystwo Ludoznawcze.

Lucchesi Palli E. 1994, Untersuchungen zum Inhalt der Bullae und anderer Amulettkapseln in Antike, Spätantike und im Frühen Mittelalter, w: M. Jordan-Ruwe, U. Real (red.), Bild- und Formensprache 
der spätantike Kunst. Hugo Brandenburg zum 65. Geburstag, Boreas 17, Münster, Westfälische Wilhelms-Universität Münster, s. 171-176.

Lurker M. 1989, Stownik obrazów i symboli biblijnych, Poznań, Pallotinum.

Łęga W. 1930, Kultura Pomorza we wczesnem średniowieczu na podstawie wykopalisk, Toruń, Towarzystwo Naukowe w Toruniu.

Łukaszyk A. 2012, Wierzchowce Bogów. Motyw konia w wierzeniach Stowian i Skandynawów. Szczecin, Triglav.

Macháček, J., Dresler P., Přichystalová R., Sládek V. 2016, Břeclav-Pohansko VII. Kostelní pohřebiště na Severovýchodním předhradi, Brno, Filozoficka fakulta, Masarykova univerzita.

Marciniak J. 1960, Cmentarzysko szkieletowe z okresu wczesnośredniowiecznego w Strzemieszycach Wielkich pow. Będzin, „Materiały Wczesnośredniowieczne“ 5, s. 141-186.

Mařík J. 2009, Libická sídelní aglomerace a její zázemí v raném středověku, Dissertationes Archaeologicae Brunenses/Pragensesque 7. Praha: Univerzita Karlova v Praze Filozofická fakulta.

Matla M. 2020, Wptywy czeskie i morawskie $w$ kulturze materialnej ziem polskich $w$ dobie formowania się państwa wczesnopiastowskiego i ich geneza, „Historia Slavorum Occidentis“ 2, s. 151-202.

Mecking O. 2018-2019, Zu den Farben von archäologischen Kupferlegierungen mit den Legierungselementen Zinn, Zink, Blei, Silber, Nickel und Antimon, „Alt-Thüringen” 46, s. 193-217.

Mianecki A. 2012, Przekleństwo królów, plaga królestw - smok w wybranych opowieściach polskiego folkloru tradycyjnego, w: K. Konarska (red.), Powodzie, plagi, życie i inne katastrofy, Colloquia Anthropologica et Communicativa 5, Wrocław, Wydawnictwo Uniwersytetu Wrocławskiego, s. 477-494.

Miazga B., Rodak S., Lucejko J.J., Ribechini E. 2020, A unique early medieval pendant (kaptorga) from Opole Groszowice (Silesia, SW Poland) in the light of interdisciplinary archaeometric studies, "Sprawozdania Archeologiczne" 72(2), s. 539-554.

Michniewicz M. 2015, Wyniki ekspertyzy botanicznej drewna z wnętrza kaptorg, w: J. Wrzesiński, A.M. Wyrwa (red.), Srebrny naszyjnik z kaptorgami i krzyżowata zawieszka z Dziekanowic, Lednica, Muzeum Pierwszych Piastów na Lednicy, s. 107-108.

- 2012, Uwagi botanika o resztkach roślinnych z grobów z cmentarzyskach w Lubieniu, pow. piotrkowski, w: T. Kurasiński, K. Skóra, Wczesnośredniowieczne cmentarzysko szkieletowe w Lubieniu, pow. piotrkowski, Łódź, Ośrodek Badań nad Dawnymi Technologiami IAE PAN, s. 333-338.

Milinković M. 2013, Frühchristliche Reliquiare und Kapseln in Serbien, "Mitteilungen zur christlichen Archäologie" 19, s. 27-39.

Mödlinger M., Kuijpers M.H.G., Braekmans D., Berger D. 2017, Quantitative comparisons of the color of CuAs, CuSn, CuNi, and CuSb alloys, "Journal of Archaeological Science" 88, s. 14-23.

Musianowicz K. 1948-1949, Kabłączki skroniowe - próba typologii i chronologii, ,Światowit” 20, s. 115-232.

- 1950-1951, Cmentarzysko i osada wczesnohistoryczna w Gozdowie, pow. Sierpc, „Wiadomości Archeologiczne" 17(4), s. 251-305.

Nadolski A., Abramowicz A., Poklewski T. 1959, Cmentarzysko z XI wieku w Lutomiersku pod Łodzia, Acta Archaeologica Universitatis Lodziensis 7, Łódź, Zakład Narodowy im. Ossolińskich we Wrocławiu.

Naum M. 2005-2006, Early Christians, Immigrants and Ritualised Practice. A Case Study of South-eastern Bornholm, "Lund Archaeological Review" 11-12, s. 17-36.

Naum M. 2008, Homelands Lost and Gained. Slavic Migration and Settlement on Bornholm in the Early Middle Ages, Lund Studies in Historical Archaeology 9, Lund, Lund University.

Nedoshivina N.G. 1997, Drevnerusskiye amulety $v$ vide miniatyurnykh predmetov byta $i$ ikh rol'v pogrebal'nom obryade, w: I.V. Belotserkovskaya (red.), Arkheologicheskiy sbornik. Pogrebal'nyy obryad, Trudy Gosudarstvennogo istoricheskogo muzeya 93, Moskva, Gosudarstvennyy istoricheskiy muzey, s. $80-108$.

Nesen I. 2003, Kul'turni symvoly davnyny: kin'u vesil'nomu rytuali (za materialamy Tsentral'noho Polissya), ,Sotsium” 3, s. 263-268.

Nowakiewicz T. 2013, Niemonetarna część skarbu z Mózgowa, w: J. Sobieraj (red.), Średniowieczne skarby srebrne z Pojezierza Iławskiego w zbiorach Muzeum Warmii i Mazur, Olsztyn, Muzeum Warmii i Mazur, s. 145-175. 
Nowiński J. 2011, Agnusków zapomniana moc, sława i piękno - rzecz o papieskim Agnus Dei, „Seminare" 30 , s. 245-267.

Opravil E., Lutovský M. 1993, Obsah kaptorgy z Dobrovize, „Archeologické rozhledy” 45(1), s. 139-142.

Ornan T. 2005, The Triumph of the Symbol. Pictorial Representation of Deities in Mesopotamia and the Biblical Image Ban, Fribourg-Göttingen, Academic Press Fribourg, Vandenhoeck \& Ruprecht.

Panfil T. 1999-2000, „,Na lwa srogiego bez obrazy wsiędziesz”. O niektórych znaczeniach symbolicznych średniowiecznych wyobrażeń lwa, „Summarium” 28-29, s. 81-94.

Paternoga M. 2003, Stanowisko $n r 1$ we Wszemirowie, pow. Trzebnica, w świetle dawniejszych i najnowszych badań, „Śląskie Sprawozdania Archeologiczne” 45, s. 157-174.

Pawlak P. 1997, Wyniki badań archeologicznych na Śródce w Poznaniu, „Kronika Miasta Poznania” 1, s. 9-39.

- 1998, Wczesnośredniowieczne cmentarzysko „szkieletowe” w Poznaniu-Śródce w świetle badań w 1994 roku, ,Slavia Antiqua” 39, s. 215-282.

Pawlak E., Pawlak P. 2015, Serce miasta jest po prawej stronie. Archeologia o przeszłości poznańskiej Śródki i Ostrówka, Poznań, Wydawnictwo Kontekst.

- 2018, Poznań, ul. Śródka 7 - badania wykopaliskowe w 2017 roku, w: J. Wierzbicki (red.), Badania archeologiczne na Nizinie Wielkopolsko-Kujawskiej w latach 2013-2017, Poznań, Instytut Archeologii UAM, s. 179-191.

Pawlak P., Sikorski A. 1995, Tekstylia z wczesnośredniowiecznego cmentarzyska ,szkieletowego” w Poznaniu-Śródka, „Wielkopolskie Sprawozdania Archeologiczne” 3, s. 128-138.

Pawlicka E., Wrzesiński J. 2019, Omówienie wyników badań prowadzonych w ramach projektu Wykonanie analiz laboratoryjnych biżuterii wczesnośredniowiecznej i dokumentacji technicznej dla stanowiska Dziekanowice 22, w: J. Wrzesiński (red.), Groby z biżuteria wczesnośredniowiecznego cmentarzyska w Dziekanowicach 2, Biblioteka Studiów Lednickich Fontes 8:2, Lednica, Muzeum Pierwszych Piastów na Lednicy, s. 463-478.

Płoszaj T., Jędrychowska-Dańska K., Zamerska A., Drozd-Lipińska A., Poliński D., Janowski A., Witas H. 2017, Ancient DNA analysis might suggest external origin of individuals from chamber graves placed in medieval cemetery in Pień, Central Poland, "Anthropologischer Anzeiger" 74(4), s. 319-337.

Płoszaj T., Jędrychowska-Dańska K., Zamerska A., Lewandowska M., Bojarski J., Chudziak W., DrozdLipińska A., Agnieszka Robaszkiewicz A., Witas H.W. 2020, Analysis of maternal lineage structure of individuals from chamber graves placed in medieval cemetery in Katdus, Central Poland, "Homo" 71(1), s. 43-50.

Porzeziński A. 2006, Wczesnośredniowieczne cmentarzysk o szkieletowe na stanowisku $2 a$ w Cedyni, województwo zachodniopomorskie, Szczecin, Muzeum Narodowe w Szczecinie.

Price T.D., Frei K.M. 2016, Badania izotopowe pochówków z Bodzi, w: A. Buko (red.), Bodzia. Elitarny cmentarz z początków państwa polskiego, Warszawa, Wydawnictwo IAE PAN, s. 425-435.

Profantová N. 2013, Ke změnám ve vývoji hmotné kultury 10. století v Čechách, „Archaeologia Historica" 38(1), s. 27-44.

Profantová N., Daněček D. 2017, Nová střibrná kaptorga ze středních Čech v souvislosti s konkrétním výrobnim okruhem(?) v Praze, "Slavia Antiqua" 58, s. 91-113.

Profantová N., Šilhová A. 2010, Raně stredověké kaptorgy v Čechách. Analýza nálezu z hrobu č. 22 na pohřebišti Klecany II, „Památky archeologické” 101, s. 283-310.

Profantová N., Špaček J., Novotná M. 2011, Nové poznatky o výrobě a obsahu kaptorg na základě studia hrobi̊ ze Zelenče a Čelákovic, okr. Praha-Východ, "Archeologie ve str̆edních Čechách" 15, s. 539-552.

Quast D. 2009, Christian relics in early medieval graves, "Gausac" 34-35, s. 35-44.

Rajewski Z. 1973, Koń w wierzeniach u Stowian wczesnośredniowiecznych, „Wiadomości Archeologiczne" 39(4), s. 231-237.

Ratajczyk Z., Wadyl S. 2019, Historia badań cmentarzyska, w: S. Wadyl (red.), Ciepte. Elitarna nekropola wczesnośredniowieczna na Pomorzu Wschodnim, Gdańsk, Muzeum Archeologiczne w Gdańsku, s. 15-27.

Rennwanz J. 2019, Analiza archeobotaniczna zawartości kaptorgi z wczesnośredniowiecznego cmentarzyska w Dziekanowicach, stan. 22. Grób 7/96, w: J. Wrzesiński (red.), Groby z biżuteriq wczesnośredniowiecznego cmentarzyska w Dziekanowicach 2, Biblioteka Studiów Lednickich Fontes 8:2, Lednica, Muzeum Pierwszych Piastów na Lednicy, s. 355. 
Rodak S. 2017, Podstawy datowania grodów z końca X-początku XIII wieku na Dolnym Śląsku, In pago Silensi. Wrocławskie Studia Wczesnośredniowieczne 4, Wrocław, Instytut Archeologii Uniwersytetu Wrocławskiego.

Rosiński B. 1950-1951, Charakterystyka antropologiczna kostnych szczątków ludzkich cmentarzyska wczesnośredniowiecznego w Radomiu, „Wiadomości Archeologiczne” 17(4), s. 327-340.

Rozmus D., Szmoniewski B.Sz. 2010, Badania archeologiczne na wczesnośredniowiecznej osadzie produkcyjnej w Dąbrowie Górniczej-Łośniu (stanowisko 8), województwo ślaskie, w: E. Tomczak (red.), Badania archeologiczne na Górnym Ślasku i ziemiach pogranicznych w latach 2007-2008, Katowice, Centrum Dziedzictwa Kulturowego Górnego Śląska, s. 133-140.

Rudenko K.A. 2011, Bulgarskoye zoloto. Filigrannyye visochnyye podveski, Drevnosti Bilyara 1. Kazan', Izdatel'stvo Zaman.

Rzepecki S., Kot K., Piotrowska M. 2016, Pod prąd czasu. Kwiatków i okolica w pradziejach, Łódź, Instytut Archeologii Uniwersytetu Łódzkiego, Fundacja Uniwersytetu Łódzkiego, Łódzka Fundacja Badań Naukowych, Urząd Gminy Brudzew.

Schorta R. 2005, Textilreliquien und textile Reliquienhüllen, "Kunst und Architektur in der Schweiz" 56(1 - Kunst und Liturgie im Mittelalter), s. 12-19.

Shellhas U. 1994, Amulettkapsel und Brustschmuck - Neue Beobachtungen zur rheinhessischen Frauenkleidung des 7. Jahrhunderts, "Mainzer Archäologische Zeitschrift" 1, s. 73-155.

Sikora J. 2012, Kości, zapinki, DNA czy broń? Problematyka etniczna w badaniach wczesnośredniowiecznych cmentarzysk szkieletowych $w$ Polsce, w: W. Dzieduszycki, J. Wrzesiński (red.), Obcy, Funeralia Lednickie 14, Poznań, SNAP Oddział w Poznaniu, s. 333-344.

- 2013a, Ethnos or ethos? Some remarks on interpretation of early medieval elite burials in northern Poland, w: S. Moździoch, B. Stanisławski, P. Wiszewski (red.), Scandinavian Culture in Medieval Poland, Wrocław, Wydawnictwo IAE PAN, s. 411-436.

- 2013b, O interpretacji etnicznej wczesnośredniowiecznych pochówków elitarnych. Skandynawowie w państwie pierwszych Piastów i na Pomorzu?, „Slavia Antiqua” 54, s. 61-96.

- 2015, Początki inhumacji w Polsce pierwszych Piastów. Jak wczesne?, w: W. Dzieduszycki, J. Wrzesiński (red.), Cmentarzyska - relacje społeczne i międzykulturowe, Funeralia Lednickie 17, Poznań, SNAP Oddział w Poznaniu, s. 151-164.

Sikorski A. 2015, Sznurek z kaptorg grobu komorowego, w: J. Wrzesiński, A.M. Wyrwa (red.), Srebrny naszyjnik z kaptorgami i krzyżowata zawieszka z Dziekanowic, Lednica, Muzeum Pierwszych Piastów na Lednicy, s. 95-98.

- 2019, Wyroby tekstylne z cmentarzyska w Dziekanowicach, w: J. Wrzesiński (red.), Groby z biżuteria wczesnośredniowiecznego cmentarzyska w Dziekanowicach 2, Biblioteka Studiów Lednickich Fontes 8:2, Lednica, Muzeum Pierwszych Piastów na Lednicy, s. 327-344.

Sikorski M. 2015, Smoki i smokobójstwo, Stradunia, Wydawnictwo Sativa Studio.

Skubiszewski P. 2001, Sztuka Europy łacińskiej od VI do IX wieku, Lublin, Towarzystwo Naukowe KUL.

Skóra K., Kurasiński T. 2012, Nietypowe przedmioty w wyposażeniu dwóch pochówków z cmentarzyska wczesnośredniowiecznego w Radomiu, st. 4, „Światowit” 9(50)/B, s. 193-212.

Sobkowiak-Tabaka I. 2016, Katalog grobów i ich wyposażenia (wersja skrócona), w: A. Buko (red.), Bodzia. Elitarny cmentarz z początków państwa polskiego, Warszawa, Wydawnictwo IAE PAN, s. 67-82.

Solik R. 2003, Motywy zoomorficzne w kulturze artystycznej średniowiecza. Rekonesans, „Język a Kultura" 15 , s. 63-80.

Staecker J. 1997, Legends and Mysteries: Reflections on the Evidence of the Early Mission in Scandinavia, w: H. Andersson, P. Carelli, L. Ersgård (red.), Visions of the Past. Trends and Traditions in Swedish Medieval Archaeology, Lund-Stockholm, Central Board of National Antiquities, s. 419-454.

Starnawska M. 2008, Świętych życie po życiu. Relikwie w kulturze religijnej na ziemiach polskich w średniowieczu, Warszawa, Wydawnictwo DiG.

- 2017, Kult relikwii w Polsce X-XII w. i jego rola w chrystianizacji społeczeństwa, w: J. Tyszkiewicz, K. Łukawski (red.), Pierwsze wieki chrześcijaństwa w Polsce: do roku 1200, Pułtusk, Akademia Humanistyczna im. A. Gieysztora, Akademickie Towarzystwo Edukacyjno-Naukowe ATENA, s. 43-56.

Stattler E. 1966, Kontakty handlowe ludności wczesnopolskiej z krajami arabskimi we wczesnym średniowieczu (IX-XI w.), ,Slavia Antiqua” 13, s. 199-269. 
Stawska V. 2003, Cmentarzyska wczesnośredniowieczne z ziemi chetmińskiej w świetle najnowszych badań, w: W. Chudziak (red.), Studia nad osadnictwem ziemi chetmińskiej 5, Toruń, Wydawnictwo UMK, s. 89-108.

Stawska V., Weinkauf, J., Kozłowski T. 2006, Katalog źródel, w: W. Chudziak (red.), Wczesnośredniowieczne cmentarzysko szkieletowe w Katdusie (stanowisko 1), Mons Sancti Laurentii 3, Torun, Instytut Archeologii UMK, s. 321-388.

Stenberger M. 1954, Die Schatzfunde Gotlands der Wikingerzeit, 1 Stockholm, Almqvist \& Wiksell.

Stepanova Ju.V. 2020, Izdeliya iz tsvetnogo metalla iz raskopok na territorii Taynitskogo sada Moskovskogo Kremlya 2007 g, „Kratkiye soobshcheniya Instituta arkheologii“ 259, s. 283-300.

Strobin J. 2015, Konserwacja i wykonanie repliki naszyjnika, w: J. Wrzesiński, A.M. Wyrwa (red.), Srebrny naszyjnik z kaptorgami i krzyżowata zawieszka z Dziekanowic, Lednica, Muzeum Pierwszych Piastów na Lednicy, s. 119-155.

- 2019, Technologia wybranych ozdób z cmentarzyska w Dziekanowicach, w: J. Wrzesiński (red.), Groby z bizuteriq wczesnośredniowiecznego cmentarzyska w Dziekanowicach, 2, Biblioteka Studiów Lednickich Fontes 8:2, Lednica, Muzeum Pierwszych Piastów na Lednicy, s. 357-389.

Suchodolski S. 2015, Moneta z grobu 62/08, w: J. Wrzesiński, A.M. Wyrwa (red.), Srebrny naszyjnik z kaptorgami i krzyżowata zawieszka z Dziekanowic, Lednica, Muzeum Pierwszych Piastów na Lednicy, s. 91-93.

- 2016, Obol zmarlych, w: A. Buko (red.), Bodzia. Elitarny cmentarz z poczatków państwa polskiego, Warszawa, Wydawnictwo IAE PAN, s. 285-303.

- 2018, Czeskie monety z X-XI wieku z cmentarzysk w miejscowościach Bodzia i Dziekanowice (Polska). „Numismatické listy” 73(1-2), s. 19-32.

Szczepanik P. 2020, Rzeczywistość mityczna Stowian pólnocno-zachodnich i jej materialne wyobrażenia, Torun, Wydawnictwo Naukowe UMK.

Szczepkowska-Naliwajek K. 1996, Relikwiarze średniowiecznej Europy. od IV do początku XVI wieku. Geneza, treści, styl i techniki wykonania, Warszawa, Fundacja ATK.

- 2000, [Głos w dyskusji], w: M. Barbasiewicz (red.), Początki tysiaclecia. Autoryzowany zapis dwóch konferencji, Warszawa, Towarzystwo Opieki nad Zabytkami, s. 26-27.

Sztyber A. 2008, Kaptorgi. Przykład kunsztu wczesnośredniowiecznego zlotnictwa, „Alma Mater” 99, s. 283-286.

- 2010, Funkcja i znaczenie kaptorg we wczesnym średniowieczu, w: P. Kucypera, S. Wadyl (red.), Życie codzienne przez pryzmat rzeczy, Toruń, Wydawnictwo Naukowe UMK, s. 43-62.

Šolle M. 1959, Knižecí pohřebiště na Staré Kouřimi, „Památky archeologické” 50(2), s. 353-506.

- 1966, Stará Kouřim a projevy velkomoravské hmotné kultury v Čechách, Praha, Academia.

Štefan I. 2004, Kaptorgy: pokus o kontextuálni analýzu, „Studia Mediaevalia Pragensia” 5, s. 21-60.

Štefanovičová T. 2000, K otázke významu predmetu ako amuletu, „Studia Archaeologica Brunensia” 49, s. 113-117.

Tabaczyński S. 1958, Z badań nad wczesnośredniowiecznymi skarbami srebrnymi Wielkopolski, Wrocław-Warszawa, Zakład Narodowy im. Ossolińskich, Wydawnictwo PAN.

Tokaj J. 2009, Wyobrażenie gryfa na katordze z cmentarzyska w Dąbrowie Górniczej-Strzemieszycach Wielkich, w: D. Rozmus, S. Witkowski (red.), Gospodarka nad Przemszq i Brynica od pradziejów do poczatków XX wieku w świetle badań interdyscyplinarnych, Dąbrowa Górnicza-Olkusz-Sosnowiec, Muzeum Miejskie „Sztygarka” w Dąbrowie Górniczej, PTTK Olkusz, Instytut Zagłębiowski Wyższej Szkoły Humanitas, s. 240-243.

Turek R. 1962, Zlomkové střibro z kelčského nálezu, „Numismatický sborník” 7, s. 83-117.

- 1976, Libice. Pohřebiště na vnitřním hradisku, „Sborník Národního muzea v Praze”, seria A - „Historie" 30(5), s. 249-316.

- 1978, Libice. Hroby na libickém vnitřním hradisku, „Sborník Národního muzea v Praze”, seria A „Historie” 32(1-4), s. 1-150.

Ungerman Š. 2007, Amulety v dětských hrobech na raně středověkém pohřebišti v Dolnich Věstonicích -Na piskách, „Študijné zvesti Archeologického ústavu SAV” 42, s. 221-237. 
Urbańczyk P. 2015, Jak (s)chowano pierwszych polskich chrześcijan?, w: W. Dzieduszycki, J. Wrzesiński (red.), Cmentarzyska - relacje społeczne i międzykulturowe, Funeralia Lednickie 17, Poznań, SNAP Oddział w Poznaniu, s. 129-142.

- 2020, Dialog międzyreligijny w sztuce wczesnopiastowskiej, „Saeculum Christianum” 27(1), s. 31-40.

Urbańska H. 1959, Wczesnopolskie cmentarzysko rzędowe koło Groszowic w pow. opolskim, „Zeszyty Naukowe Uniwersytetu Wrocławskiego”, seria A(19), „Archeologia Śląska” 2, s. 165-189.

Van Buren E.D. 1939, The Rosette in Mesopotamian Art, "Zeitschrift für Assyriologie und Vorderasiatische Archäologie" 45(2-3), s. 99-107.

Vavák J. 2015, Koniec moravského démona? Príspevok $k$ identifikácii výjavu na včasnostredovekom honosnom opasku z Břeclavi-Pohanska, "Zborník Slovenského národného múzea" 109, "Archeológia" 25, s. 239-255.

Vida T. 1995, Frühmittelalterliche scheiben- und kugelförmige Amulettkapseln zwischen Kaukasus, Kastilien und Picardie, „Bericht der Römisch-Germanischen Kommission“ 76, s. 219-288.

- 2009, Herkunft und Funktion von Privatreliquiaren und Amulettkapseln im frühgeschichtlichen Europa, w: U. von Freeden, H. Friesinger, E. Wamers (red.), Glaube, Kult und Herrschaft. Phänomene des Religiösen im 1. Jahrtausend n. Chr. in Mittel- und Nordeuropa. Akten des 59. Internationalen Sachsensymposions und der Grundprobleme der frühgeschichtlichen Entwicklung im Mitteldonauraum, Bonn, Dr. Rudolf Habelt GmbH, s. 261-280.

Wachowski K. 1975, Cmentarzyska doby wczesnopiastowskiej na Śląsku, Wrocław-Warszawa-KrakówGdańsk, Zakład Narodowy im. Ossolińskich, Wydawnictwo PAN.

Wamers E. 1995, Eine burgundische Pyxis 'vom Niederrhein'. Zu merowingerzeitlichen Amulettkapseln und Kosmetikbüchsen, "Frühmittelalterliche Studien" 29, s. 144-166.

Wawrzeniuk A. 2016, Magia ochronna Słowian we wczesnym średniowieczu na ziemiach polskich, Warszawa, Wydawnictwo UKSW.

Weidemann M. 1977, Reliquie und Eulogie. Zur Begriffsbestimmung geweihter Gegenstände in der Fränkischen Kirchenlehre des 6. Jahrhunderts, w: J. Werner (red.), Die Ausgrabungen in St. Ulrich und Afra in Augsburg 1961-1968, Münchner Beiträge zur Vor- und Frühgeschichte 23. München, C.H. Beck'sche Verlagsbuchhandlung, s. 353-373.

Wiklak H. 1960, Cmentarzysko z XII i XIII w. w Poddębicach, „Prace i Materiały Muzeum Archeologicznego i Etnograficznego w Łodzi. Seria Archeologiczna” 5, s. 183-207.

Wilhelm z Rubruk 2007, Opis podróży, przeł. M. Olszewski, Kęty, Wydawnictwo Marek Derewiecki.

Wiśniewski M., Kotlewski L. (red.) 2013, Badania archeologiczne w pasie budowy Autostrady A1 w granicach województwa kujawsko-pomorskiego. Katalog zabytków, Bydgoszcz, Generalna Dyrekcja Dróg Krajowych i Autostrad Oddział w Bydgoszczy.

Wołoszyn M. 2003, Czy kobiety szybciej i chętniej niż mężczyźni ulegały chrystianizacji?, w: W. Dzieduszycki, J. Wrzesiński (red.), Kobieta - śmierć - mężczyzna, Funeralia Lednickie 5, Poznań, SNAP Oddział w Poznaniu, s. 81-92.

Wrzesińska A. 1999, Wyniki analizy antropologicznej szczątków kostnych z cmentarzyska w Poznaniu-Śródce, „Archeologia Polski” 44(1-2), s. 117-137.

Wrzesiński J. 2015, Grób ze srebrnym naszyjnikiem z Dziekanowic, w: J. Wrzesiński, A.M. Wyrwa (red.), Srebrny naszyjnik z kaptorgami i krzyżowata zawieszka z Dziekanowic, Lednica, Muzeum Pierwszych Piastów na Lednicy, s. 13-65.

- 2019, Biżuteria pochowanych $w$ grobach cmentarzyska $w$ Dziekanowicach, w: J. Wrzesiński (red.), Groby z biżuteria wczesnośredniowiecznego cmentarzyska w Dziekanowicach 1, Biblioteka Studiów Lednickich Fontes 8:1, Lednica, Muzeum Pierwszych Piastów na Lednicy, s. 13-91.

Wrzesiński J. (red.) 2019, Groby z biżuteria wczesnośredniowiecznego cmentarzyska w Dziekanowicach 2, Biblioteka Studiów Lednickich Fontes 8:1, Lednica, Muzeum Pierwszych Piastów na Lednicy.

Zawol M. 2015, Srebrna kaptorga trapezowata z Biskupina, stanowisko 4, w: S. Nowaczyk, A. Grossman, W. Piotrowski (red.), IV Sprawozdanie Biskupińskie, Biskupin, Muzeum Archeologiczne w Biskupinie, s. 103-127.

- 2018, Motywy dekoracyjne kaptorg trapezowatych z terenów ziem polskich - próba interpretacji, w: B. Gediga, A. Grossman, W. Piotrowski (red.), Inspiracje i funkcje sztuki pradziejowej $i$ wczes- 
nośredniowiecznej, Biskupin-Wrocław, Muzeum Archeologiczne w Biskupinie, Polska Akademia Nauk - Oddział we Wrocławiu, s. 467-490.

Zhilina N.V. 2002, Drevnerusskaya podveska-korobochka («kaptorga» li?), „Kratkiye soobshcheniya Instituta arkheologii” 222, s. 169-179.

Zoll-Adamikowa H. 1971, Wczesnośredniowieczne cmentarzyska szkieletowe Małopolski 2, WrocławWarszawa-Kraków-Gdańsk, Zakład Narodowy im. Ossolińskich, Wydawnictwo PAN.

Żółkowska J. 2010, Funkcja dewocjonaliów chrześcijańskich na przykładzie wybranych grobów na cmentarzyskach wczesnośredniowiecznych i nowożytnych, w: W. Dzieduszycki, J. Wrzesiński (red.), Tak więc po owocach poznacie ich, Funeralia Lednickie 12, Poznań, SNAP Oddział w Poznaniu, s. 241-249. 